\title{
Análisis de una decadencia. La arqueología española del siglo XIX. I. El impulso isabelino (1830-1867)
}

\author{
Alfredo Mederos Martín*
}

\begin{abstract}
Resumen
Hasta 1857 no existieron asignaturas de Historia Universal o Historia de España en los estudios universitarios de Filosofía y Letras. La creación de la Escuela Superior de Diplomática, en 1856, introdujo la asignatura de Arqueología y Numismática y desde 1863, la Epigrafía y la Historia de las Bellas Artes. Tampoco existía un Museo Nacional de Arqueología, que se solicitó desde 1830, pero no se fundó hasta 1867. No obstante, surgieron museos arqueológicos provinciales, vinculados a grandes yacimientos romanos, Sevilla (1835) por Italica, Tarragona (1836) por Tarraco o Mérida (1838) por Emerita Augusta. La desamortización de 1836 y la creación de las Comisiones Provinciales de Monumentos Históricos y Artísticos, bajo competencia de la Real Academia de Bellas Artes de San Fernando hasta 1865, impulsó la creación de nuevos museos provinciales. Ante la ausencia de suficientes especialistas en la Real Academia de la Historia, Escuela Superior de Diplomática y las universidades, las clases medias burguesas asumieron el estudio de la arqueología. Se organizaron en la Academia Española de Arqueología, 1837/44-1860/68, que llegó a contar con 33 sociedades provinciales, incluyendo Cuba y Filipinas, mientras la docencia en Arqueología Monumental se impartió en el Ateneo de Madrid desde 1837. A partir de la Unión Liberal de O'Donnell hubo un incremento en la financiación de las excavaciones, que se trató de regular con una Ley de Excavaciones y Antigüedades y un Plan General de Excavaciones pero la revolución de 1868 paralizó ambas iniciativas. Los arqueólogos con plaza institucional tuvieron una formación poco especializada, generalmente estudios de derecho. La mayor parte tuvieron que venir a trabajar a Madrid, donde estaba la Universidad Central y la Escuela Superior de Diplomática. Las figuras más relevantes fueron dos académicos nacidos en Baena (Córdoba) y Sevilla, José Amador de los Ríos y Antonio Delgado, junto con Manuel Rodríguez de Berlanga de Málaga. La investigación arqueológica española tuvo una mínima repercusión internacional.
\end{abstract}

PALABRAS CLAVE: arqueología española, siglo XIX, historiografía, romanticismo, arqueología monumental, ascenso burguesía.

\begin{abstract}
Until 1857, there were no courses in World History or History of Spain in the faculties of Arts. The creation of the Highest Diplomatic School, in 1856, introduced the subjects of Archaeology and Numismatics and since 1863, Epigraphy and History of Fine Arts. There was not a National Museum of Archaeology, which was requested in 1830, but it was not founded until 1867. However, provincial archaeological museums emerged, linked to major Roman sites, Sevilla (1835) to Italica, Tarragona (1836) to Tarraco and Merida (1838) to Emerita Augusta. The ecclesiastical confiscations of 1836 and the creation of the Provincial Commissions of Historical and Artistic Monuments, under jurisdiction of the Royal Academy of Fine Arts of San Fernando until 1865, promoted the creation of new provincial museums. In the absence of enough specialists at the Royal Academy of History, Highest Diplomatic School and universities, the middle bourgeois classes assumed the study of Archaeology. They were organized in the Spanish Academy of Archaeology, 1837/441860/68, that once numbered 33 provincial societies at 1844, including Cuba and the Philippines, while Monumental Archaeology teaching was held at the Athenaeum of Madrid since 1837. From O'Donnell's Liberal Union was an increase in funding for excavations, which was intended to be regulated with an Excavations and Antiquities Act and a General Plan of Excavations, but the Revolution of 1868 stopped both initiatives. Archaeologists with academic positions had little specialized training, law degree generally. Most of them had to come and work at Madrid, where it was the Central University and the Highest Diplomatic School. The most relevant figures were two scholars born in Cordoba and Seville, José Amador de los Ríos and Antonio Delgado, together with Manuel Rodríguez de Berlanga from Malaga. Spanish archaeological research had minimal international repercussion.
\end{abstract}

KEY WORDS: Spanish archaeology, nineteenth century, historiography, romanticism, monumental archaeology, rising bourgeoisie. 


\section{INTRODUCCIÓN:}

\section{CAUSAS DE LA CRISIS DEL SIGLO XIX}

A partir de 1780 comenzó el proceso de revolución industrial en el Reino Unido y continuó imparable paralelo a las guerras napoleónicas. Inicialmente fue la industria textil del algodón entre 1780-90, a la que se sumó la fundición de lingotes de hierro entre 1790-1800 y desde 1830-40 la de raíles de ferrocarril. Nuestro país vecino más inmediato, Francia, tuvo también un desarrollo retardado pero con mayor intensidad, textil de algodón desde 1815-20, raíles de ferrocarril desde 1840 y fundición de hierro desde 1830, aunque éste no fue verdaderamente importante hasta 1850 (Beaud, 1984: 117 cuadro 3). España no estaba en las mejores condiciones para el despegue industrial por una serie de factores, unos políticos y otros estructurales.

La Guerra de la Independencia había dejado prácticamente 20 años perdidos, como recoge una memoria presentada en las Cortes en 1820 sobre la producción agraria, la cosecha de 60 millones de fanegas de cereal en 1799 aún no se había recuperado y sólo alcanzaba 51 millones en 1818 . De los 49 millones de arrobas de vino sólo se obtuvieron 37 millones y de los 6 millones de arrobas de aceite sólo se alcanzaban 3 millones (Artola, 1973: 59).

La pérdida del imperio americano también impidió una recuperación basada en las rentas y comercio exterior, pues el volumen del comercio en 1827 había descendido un $75 \%$ respecto del existente en 1792 (Artola, 1973: 79 n. 22).

Un tercer aspecto fue que la monarquía y las élites políticas no estuvieron a la altura debida, grave problema que se arrastró durante buena parte del siglo XIX. Fernando VII, la regencia de María Cristina, Isabel II, Amadeo I, Alfonso XII y la regencia de María Cristina de Habsburgo son representativos de una sucesión de monarcas débiles, los cuales facilitaron que los militares, en particular Espartero, Narváez, O’Donnell y Serrano, se creyeran los salvadores de la estabilidad del país, papel que desempeñaron durante la Restauración dos políticos, Cánovas y Sagasta, quienes a su vez fueron "tutorizados" internacionalmente por las grandes potencias europeas. La propia inestabilidad en la sucesión de la corona favoreció el carlismo y las tres guerras civiles. La ausencia de descendencia de Fernando VII hasta casi el final de su vida propició la primera, la elección del marido de Isabel II sometida a las presiones internacionales provocó la segunda y la poco comprensible elección como rey de Amadeo I entre varios candidatos, la tercera. La surrealista vida privada de la monarquía los deslegitimó ante el pueblo, la oligarquía y los militares. La regente María Cristina de Borbón y Dos Sicilias, cuarta mujer de Fernando VII, tuvo 8 nuevos hijos, 5 de ellos mientras era Regente con el guardia de corps Fernando Muñoz, mientras Isabel II tuvo 12 hijos de diferentes parejas, ninguno de su marido y rey consorte, Francisco de Asis, lo que dificultó la elección de Alfonso XII, el sexto, por ser hijo con el capitán de ingenieros Enrique Puigmoltó y Mayans.

Entre los factores estructurales que dificultaron la revolución industrial se encontraban los elevados costos del transporte interior, por la orografía de la Península Ibérica, que suponían en el reinado de Carlos III la construcción de un puente cada 3.5 km. (Artola, 1973: 93), red de puentes que quedó seriamente dañada después de la Guerra de la Independencia. Por otra parte, estaba la no navegabilidad de la mayor parte de los ríos que impedía crear una red de canales para mercancías pesadas, frente a la elevada navegabilidad de la mayor parte de los grandes ríos atlánticos europeos en Francia, Alemania o Inglaterra. La mejor alternativa para el transporte de mercancías y personas fue desarrollar la navegación de cabotaje con mejoras en los puertos (Artola, 1973: 105), que potenció a las provincias costeras.

Otro grave problema fue la escasez de recursos energéticos como el carbón, pues los filones asturianos o leoneses eran muy profundos, pequeños e irregulares, que impiden una explotación mecanizada a cielo abierto, en comparación con los disponibles en países como Inglaterra o Alemania. Por otra parte, la hulla es impura y frágil y no produce buen coque cuando es calcinada para reducir las impurezas. La producción fue poco a poco incrementándose, pero nunca superó el 45-50 \% de las necesidades, pasando sólo de un $46 \%$ en el quinquenio 1861-65 al $56 \%$ en 1896-1900 (Tortella, 1981: 63 cuadro 5), a pesar del bajo consumo industrial en España. Sólo entre 1891-1900 la producción alcanzó volúmenes significativos, al pasar de 1 millón a 2.5 millones de toneladas (Martínez Cuadrado, 1973: 181).

El verdadero interés por el mineral de hierro en España sólo surgió con la aparición de los hornos que transformaron el hierro de fundición en acero, descubrimiento del ingeniero británico Henry Bessemer en 1855, al inyectar aire para acelerar la combustión. El acero exigía un mineral de hierro sin fósforo, y para el principal mercado, el Reino Unido, las minas de Vizcaya y Santander eran las más cercanas y próximas al mar que las minas suecas de Kiruna y Gallivare o las malagueñas (Tortella, 1981: 51). La producción de lingotes de hierro en toneladas, al inicio de esta etapa, en 1830, 
era de 680.000 en el Reino Unido, 266.000 en Francia, 100.000 en Alemania, 75.000 en Rusia y 14.300 en España. En 1880, era de 7.873.000 en el Reino Unido, 2.468.000 en Alemania, 1.725 .000 en Francia, 448.000 en Rusia y 85.000 en España (Artola, 1973: 117). En 1900, España sólo era el noveno productor de lingotes de hierro y acero, por debajo del Reino Unido, Alemania, Rusia, Francia, Imperio Austro-Húngaro, Bélgica, Suecia e incluso Luxemburgo (Tortella, 1981: 80 cuadro 5).

El motor industrial, por el capital que aportó, fue la extracción de mineral de hierro que tuvo dos incrementos importantes, el quinquenio 1870-74 que pasó de 72.500 a 578.200 y el quinquenio 1880-84 que saltó desde 936.800 a 3.632 .600 (Tortella, 1981: 53 cuadro 2). En la exportación se observa como el despegue fue también en el quinquenio 1870-74, cuando salió el $97 \%$ de la producción frente al quinquenio precedente con sólo el $27.4 \%$, siendo la media exportada entre 18601904 del 90.7 \% (Tortella, 1981: 54 cuadro 3). Así, España se convirtió en el tercer productor de mineral de hierro de Europa, pero mientras en el Reino Unido con 14.253.000 toneladas y en Alemania con 12.793.000 se destinaba a la producción interior, en la España de 1900, de una producción de 8.676.000 toneladas se exportaban, sobre todo a estos dos países, 7.823 .000 (Tortella, 1981: 56 cuadro 4), es decir, el $90.16 \%$.

Los ingresos que recibían por el mineral los propietarios de las minas favorecieron la inversión industrial y así fue apareciendo el primer alto horno de coque en 1865 (Carr, 1983: 49) y los primeros altos hornos para acero de Bilbao en 1882 (Martínez Cuadrado, 1973: 184). El combustible era accesible a buen precio pues traían coque británico en el flete de regreso los barcos que llevaban el mineral de hierro a Inglaterra. También sirvió para estimular otras industrias como las navieras, ferroviaria, eléctrica, etc.

Finalmente, España no era productor de la principal materia prima textil, el algodón, que se importaba mayoritariamente de Estados Unidos, mientras que el tradicional aprovechamiento de la lana entró en decadencia al incrementarse las roturaciones por la demanda de grano, al crecer la población y retroceder las zonas de pasto y forraje de ayuntamientos y órdenes religiosas con las desamortizaciones e incrementarse los cerramientos de tierras que dificultaban la trashumancia (Tortella, 1981: 46). La importación de algodón en rama arranca del final de la Guerra de Independencia, 1814-18, con 1.038 toneladas, con un incremento importante en el quinquenio 184448 hasta 9.517 y logrando su crecimiento más elevado entre 1854-58 cuando se alcanzaron 18.114.
Después siguieron crisis en las depresiones de $1857-58$ y $1864-68$ y la falta de algodón durante la Guerra de Secesión americana entre 1861-65, para observarse una recuperación desde 1869-73 con 23.832, hasta llegar a 64.315 entre 1894-98 (Tortella, 1981: 73, 70 cuadro 1). Los capitales iniciales provenían de los beneficios del comercio con las colonias americanas de vinos y licores de Cataluña (Carr, 1980/1983: 41), instalándose la primera máquina textil de vapor en 1833, que llegaron hasta 133 en 1851 (Fontana, 2007: 209). La guerra de Secesión americana otorgó valor estratégico al algodón egipcio, como área de producción alternativa e incrementó el interés por este país, cuando ya se estaba construyendo el canal de Suez.

De esta producción textil, en 1858, el $90.7 \%$ de los husos y el $83 \%$ de los telares estaban en la provincia de Barcelona, cuya producción se destinaba el $99.64 \%$ al mercado nacional, pues la burguesía catalana tuvo menos posibilidades de adquirir propiedades en Cataluña durante las desamortizaciones e invirtió en la industria textil (Artola, 1973: 92, 115). La ciudad de Barcelona creció de 183.787 habitantes en 1857 a 336.926 en 1877, incluso a pesar de la crisis en el sector textil entre 1857-68, y alcanzó 533.000 en 1901, de los cuales eran obreros 117.000 y de ellos más de un $50 \%$ eran del sector textil (Martínez Cuadrado, 1973: 178).

Otros problemas importantes fueron una menor demografía que algunos países europeos; la escasez de capitales nacionales, por lo que se dependió de las inversiones extranjeras; y un bajo nivel educativo. La demografía es interesante pues en 1850, aunque países como Francia tenían 36 millones y Estados Unidos 23 millones, otros como el Reino Unido sólo tenía 18 millones (Beaud, 1984: 122 cuadro 7), mientras que España en 1857 tenía 15.5 millones (Artola, 1973: 62), después de una etapa expansiva hasta 1860. Sin embargo, en 1900 había despegado la población del Reino Unido, hasta 36.9 millones y de Alemania hasta 50.6 millones, mientras que se había estancando en Francia con 40.7 millones y España de 18.6 millones (Tortella, 1981: 17 cuadro 1$)$.

La única ventaja real de España era la abundancia de recursos mineros como el cobre, plomo o hierro, y fue el factor que atrajo la primera inversión extranjera, pues estos recursos eran demandados por los mercados europeos. Parte de estas minas estaban próximas al mar, lo que facilitaba su exportación usando el ferrocarril, lo que favoreció al cobre de Huelva, el plomo de Almería y Murcia y el hierro de Vizcaya, Santander y Málaga, en cambio, no se desarrolló una importante minería de hierro al interior en Teruel, Guadalajara y León (Tortella, 1981: 49). Primero despegó la produc- 
ción de cobre a partir de 1857, que se duplicó en sólo 5 años (Artola, 1973: 92), el cual era también utilizado en la industria química para el ácido sulfúrico y la sosa cáustica. El crecimiento fue constante, sin saltos bruscos, alcanzando en el quinquenio 1875-79, 443.100 toneladas y en 1895-99, 764.200 (Tortella, 1981: 53 cuadro 2). Este despegue, en particular por las minas de Tharsis y Río Tinto, convirtió a España en el primer productor de mineral de cobre, empleando en 1889 a 9.000 mineros (Carr, 1983: 53). Otro metal importante fue el plomo, que por su bajo punto de fusión sí era exportado en barras, y pasó de 45.200 toneladas entre 1850-54 a 176.600 entre 1895-99 (Tortella, 1981: 53 cuadro 2). La producción, tanto en el hierro como en el cobre era destinada mayoritariamente a la exportación, pero también lo era el $96 \%$ del plomo o el $87 \%$ del mercurio entre 1850-1904 (Tortella, 1981: 54 cuadro 3).

\section{LA EXPANSIÓN ECONÓMICA ENTRE 1833-1864}

Después de la Guerra de Independencia y el reinado de Fernando VII se experimentó un gran crecimiento demográfico entre 1830-60, pasando de 12.1 millones a 15.5 millones (Artola, 1973: 62). A pesar de este crecimiento demográfico, la recuperación de la producción de trigo, con el incremento de la explotación de tierras en cultivo, permitió el autoabastecimiento entre 1820 y 1881 (Martínez Cuadrado, 1973: 139).

$\mathrm{Al}$ iniciarse la década moderada, en diciembre de 1844 , se estableció una normativa para la construcción de ferrocarriles, la cual resultó un fracaso porque se solicitaron multitud de concesiones entre 1845-46 que no se construyeron pues los solicitantes carecían de recursos. En 1848 se subvencionó a las compañías un $6 \%$ del capital invertido, pero sus resultados fueron muy pobres, y en 1855 apenas habían $400 \mathrm{~km}$. de vías férreas, Barcelona-Mataró inaugurado en 1848, Madrid-Aranjuez en 1841, Sama-Langreo (Santander) en 1852, ValenciaJátiva en 1854 (Fontana, 2007: 291), BarcelonaGranollers en 1854 y Madrid-Albacete en 1854.

La guerra de Crimea entre Francia, Reino Unido e Imperio Turco contra Rusia, de 1853 a 1856, favoreció durante esos años una balanza comercial favorable, por las ventas de trigo castellano, a pesar de algunos problemas de suministro interno (Tuñón de Lara, 1960/1973: 150; Fontana, 2007: 274).

Después de la crisis económica mundial de 1857-58, la abundancia de capitales en Europa, el haberse acabado el tendido principal de las redes de ferrocarriles europeas y la ley sobre concesiones de ferrocarriles de 1855, que daba ventajas y garantías al capital extranjero, favoreció su penetración masiva en España (Tuñón de Lara, 1960/1973: 139). Principalmente fue el capital francés el que se dirigió especialmente a los países mediterráneos, España, Portugal e Italia (Beaud, 1984: 136), en particular hacia la banca (Artola, 1973: 87), desde la cual se financiaron las inversiones en la red de ferrocarriles.

El motor fue la Ley general de ferrocarriles aprobada en junio de 1855, durante el Bienio Progresista de Espartero, siendo ministro de Fomento, Francisco de Luján Miguel y Romero, que garantizó el interés del capital invertido, aprobó subvenciones por 1.736 millones de reales, de los cuales 1.300 millones de reales procedían de la desamortización aprobada por Madoz en 1856, exención de aranceles a las importaciones de raíles, vagones y locomotoras y la aprobación de la Ley de sociedades de crédito en 1856 para facilitar la entrada de capital extranjero. El resultado final fue la construcción hasta 1865, en sólo 10 años, de $4.832 \mathrm{~km}$. de vías férreas, principalmente por dos compañías francesas, los Ferrocarriles del Norte de los Pereire y la compañía Madrid-ZaragozaAlicante de los Rothschild (Fontana, 2007: 280, 292), que también tenían la concesión de las minas de mercurio de Almadén (Ciudad Real).

En este periodo, después de Barcelona, Málaga se convirtió desde 1856 en la segunda provincia más industrializada del país, por delante de Madrid, con metalurgia del hierro y textiles de lana y algodón (Fontana, 2007: 208).

Entre las medidas que tendrán incidencia en la arqueología española se encuentra el traslado de la Academia de Minas de Almadén (1777) a Madrid, que pasó a denominarse Escuela de Minas en 1835. Con el impulso de la minería extractiva de cobre y plomo, comenzaron a localizándose minas con evidencias de explotaciones antiguas a partir de 1840.

Por otra parte, se había creado una escuela de ingenieros de caminos en 1799, la cual permaneció cerrada durante el reinado de Fernando VII, hasta que fue reabierta cuando se reorganizó el cuerpo de ingenieros en 1835 (Artola, 1973: 94-96). El inicio de la construcción de una red ferroviaria y las mejoras de las carreteras aumentó la importancia de los ingenieros de caminos y el interés por el estudio de las vías romanas.

\section{El PERIOdo IsAbelino 1833-68}

En un contexto internacional definido por la revolución de julio de 1830, que había provocado la caída de la monarquía borbónica en Francia, el 
inicio de esta etapa viene marcado con el nacimiento de Isabel II en octubre de 1830 , y poco después por su hermana Luisa Fernanda en enero de 1832.

El restablecimiento el 31 de marzo de 1830 de la Pragmática Sanción de 1789, que permitía heredar la corona a las mujeres, una vez que su mujer y sobrina, María Cristina de Borbón, había quedado embarazada, implicaba que el hermano del rey, Carlos, ya no sería su sucesor, sino su primera hija, Isabel. Pero ya desde 1826 (Fontana, 2007: 130132), estaban habiendo intentos realistas para alzar al poder a Carlos $\mathrm{V}$ y deponer a su hermano Fernando VII.

En 1829 se había efectuado el último intento de recuperar las antiguas colonias, con una escuálida expedición desde Cuba de 3.300 hombres, al mando del brigadier Barradas, hacia Tampico en México, que acabó fracasando (Fontana, 2007: 133-134).

Isabel II accedió al trono el 20 de junio de 1833, con sólo 3 años, siendo reina regente su madre, María Cristina de Borbón. En 1836, el congreso reconoció la independencia de las antiguas colonias americanas finalizando los años de esfuerzo económico y militar para mantenerlas.

Se estableció un sufragio restringido con sistema censitario en 1834, siguiendo los modelos de Francia desde 1814 y el Reino Unido desde 1832. En 1836 habían 65.067 electores, que ascendieron a 257.984 en 1837 y alcanzaron un máximo en 1841 con 423.787. Volvió a aplicarse un criterio restrictivo en 1846, al doblarse el mínimo de riqueza, descendiendo a 97.100 electores, que subió ligeramente a 121.770 en 1850 , y sólo dio un salto en 1854, cuando se aplicó los valores de 1837 , favoreciendo la victoria liberal y el inicio del Bienio Progresista, y en 1865 pasó a 418.271 (Martínez Cuadrado, 1973: 60 cuadro 5; Fontana, 2007: 272).

Con la revolución de 1840, tuvo que exiliarse la reina regente, teniendo Isabel II apenas 10 años, y fue nombrado nuevo regente el general Bartolomé Espartero entre 1840-43, que había derrotado a los carlistas en 1839.

El matrimonio de Isabel II con su primo, Francisco de Asis, hijo del infante Francisco de Paula, el 10 de octubre de 1846, cuando la reina cumplía 16 años, supuso el rechazo del candidato alemán, Leopoldo de Sajonia-Coburgo, vetado por Francia, y de Antonio de Orleáns, duque de Montpensier, hijo del rey de Francia, vetado por Inglaterra, mientras que el pretendiente carlista, Carlos Luis de Borbón, estaba mediatizado por su padre que exigía ser reconocido rey. Esto provocó el estallido de la segunda guerra carlista (18461849), con el pretendiente Carlos Luis de Borbón (Carlos VI), hijo de Carlos V y sobrino de Fernando VII, apoyado por Austria y Prusia. En cambio, el estamento militar, Francia e Inglaterra optaron por Isabel II.

La inoperatividad del ejército isabelino queda reflejada en que disponiendo de unos 200.000 hombres, fueran incapaces de imponerse rápidamente a los 80.000 carlistas, distribuidos en 10.000 en Cataluña, 20.000 en el Maestrazgo y unos 50.000 en Navarra, País Vasco y norte de Castilla (Fontana, 2007: 149-150), hasta que finalmente, Narváez, durante su mandato entre 1847-51, consiguió la derrota carlista.

Se sucedieron la Década Moderada (1844-54) de Narváez, el Bienio Progresista (1854-56) con Espartero y la Unión Liberal (1856-68), del general Leopoldo O'Donnell que estuvo en el poder en $1856,1858-63$ y $1865-66$.

\section{INTERVENCIONISMO COLONIAL Y RENACI- MIENTO DEL INTERÉS POR ORIENTE}

En contraposición con el periodo de la Restauración, la monarquía isabelina tomó rápidamente posición cuando se integró en la cuadruple alianza del bloque occidental liberal en 1834, lo que facilitó el reconocimiento internacional de Isabel II como nueva reina por Inglaterra y Francia, frente a la Santa Alianza del bloque continental conservador, el Imperio Austro-Húngaro y Prusia, que apoyaron a los carlistas.

También el Imperio Otomano, con el sultán Mahmud II, reconoció en 1833 a Isabel II, lo que creó unos lazos de confianza que se plasmaron durante la Guerra de Crimea de 1853 a 1856, cuando Francia y el Reino Unido apoyaron al Imperio Otomano contra Rusia, enviándose al general Prim y otros militares como asesores durante el conflicto.

A partir de 1843, hubo una serie de ataques marroquíes en los límites de Ceuta y Melilla, incluyendo el asesinato de un agente consular en 1844. Estos hechos hicieron nacer en España un grupo partidario de intervenir en Marruecos, entre los que se incluían el arabista y auditor general de ejército desde 1834, Serafín Estébanez Calderón, que solicitaban una intervención militar como había hecho Francia en Argelia, que conquistó Argel en 1830 (Cánovas del Castillo, 1883: 125-126). Sin embargo, el general Narváez, ante las presiones ingleses, firmó un acuerdo en Tánger con el Sultán Muley Soleiman el 24 de agosto de 1844, ratificado en el Convenio de Larache, donde se reconocían los límites de Ceuta, el 6 de mayo de 1845. Los cho- 
ques fronterizos continuaron y Narváez decidió ocupar militarmente las Islas Chafarinas el 6 de enero de 1848 desde Melilla y Málaga, ante los planes franceses de invadirlas.

La etapa del general Leopoldo O'Donnell y la Unión Liberal entre 1856-66, va a estar marcada por la Guerra de Marruecos debido a problemas en la frontera con los rifeños y la victoria de la batalla de Tetuán en 1860. O'Donnell desembarcó en Ceuta con 40.000 hombres en octubre de 1859 , se tomó Tetuán en febrero de 1860 y después de la victoria del río Ras en marzo, se firmó un tratado de paz en abril.

Sin embargo, no va a ser el único conflicto colonial en el que se involucre España, generalmente junto a la Francia de Napoleón III. Entre ellos estuvo la Guerra de Conchinchina entre 1858-62, que incluyó la conquista de Saigón en 1859 por una armada franco-española y tropas coloniales filipinas, permaneciendo después los franceses, pues no se concedió a España un puerto para comerciar con Filipinas y propiciar la salida de trabajadores chinos hacia las islas españolas del Caribe.

Otra campaña importante fue la intervención franco-anglo-española en México en 1861-62, por la negativa del gobierno de Benito Juárez de pagar sus deudas, desembarcando primero un contingente de 6.000 españoles al mando del general Prim en Veracruz, pero ante la decisión unilateral de Francia de imponer al emperador Maximiliano I, Archiduque de Austria, en marzo de 1862, los ingleses y españoles se retiraron. El reinado de Maximiliano I, 1863-67, terminó cuando fue fusilado en 1868.

Los territorios americanos parecieron ampliarse con la reincorporación a España entre 1861-65 de la República Dominicana desde el 16 de mayo. El país, independiente de Haití desde 1844, había sufrido sucesivas invasiones de Haití en 1844, $1845-49,1849-55$ y $1855-56$, y volvió a apoyar una guerra de independencia desde 1863, junto con Estados Unidos, hasta que se aceptó su independencia en 1865.

Un último conflicto fue la guerra de España contra Perú entre 1865-66, a la que se unieron por solidaridad Chile, Bolivia y Ecuador, pues España tomó las islas con guano de Chincha en Callao (Perú), que era la principal exportación del país, para cobrar compensaciones desde su independencia y atacó los puertos de Valparaíso (Chile) y Callao (Perú).

Esta apertura de los intereses políticos y económicos de España fuera de sus fronteras, después de la última expedición contra México en 1829, se advierte también en la labor de los cónsules, las corrientes culturales y los intereses arqueológicos.

Ya en octubre de 1856, el Anticuario Antonio Delgado solicitó en nombre de la Real Academia de la Historia, que Miguel Tenorio, Cónsul de España en Jerusalén, adquiriese antigüedades, monedas y medallas con destino a la Academia (Maier, 2008: 213). Esta iniciativa se amplió en mayo de 1859, cuando el académico arabista Serafín Estébanez Calderón convenció al Ministro de Estado, Saturnino Calderón Collantes, para que los agentes consulares y diplomáticos en África y el Levante adquiriesen manuscritos, libros y objetos de antigüedad para la Real Academia de la Historia (Maier, 2008: 232), ejemplos indicativos de la nueva política que se había inaugurado con el acceso a la presidencia del Gobierno de Leopoldo O'Donnell desde junio de 1858 y mantuvo hasta su marcha en enero de 1863.

El aspecto más importante fue la presencia de cónsules capacitados, algunos con interés en la arqueología en el Próximo Oriente. En 1863 partieron hacia Oriente dos cónsules liberales, interesados en la sociedad y religión otomana y árabe, Antonio Bernal de O'Reilly y Adolfo Rivadeneyra Sánchez. El primero, cónsul de España en Siria, Líbano y Palestina entre 1863 y 1866 (Martín Asuero, 2005: 787 n. 4), con sede en Beirut, territorio autónomo después de la intervención francesa en 1860, realizó notables descripciones de sus estancias, Viaje a Oriente, en Egipto (1878), Jerusalén, la Semana Santa (1877), En Tierra Santa: la Judea, la Samaria y la Galilea (1898) o En el Líbano, cartas y relaciones sobre la Siria (1888).

A finales de 1865 fue nombrado vicecónsul en Damasco, Adolfo de Mentaberry, que permaneció allí entre marzo de 1866 y julio de 1867, a las órdenes de Bernal de O'Reilly, hasta su traslado como primer secretario a Estambul en 1867, que refleja en su libro Viaje a Oriente, de Madrid a Constantinopla (1873). Posteriormente, estuvo un año en China, entre noviembre de 1869 y diciembre de 1870 (Martín Asuero, 2005: 778), de lo que también aporta un relato interesante, Impresiones de un viaje a China (1876).

El más destacado fue Adolfo Rivadeneyra. Hijo del editor de la Biblioteca de Autores Españoles, Manuel Rivadeneyra y de madre araucana, con quien se casó cuando residía en Chile y nació Adolfo en 1841, lo que le dio una tez morena al hijo útil en sus viajes por Oriente. Fue enviado a estudiar el bachillerato en Francia aprendiendo bien el francés, latín y griego. Después en Bélgica y Alemania estudió el alemán, inglés e italiano. Entró como intérprete -joven de lenguas- en el consulado español en Beirut en 1863, a las órdenes 
de Antonio Bernal de O'Reilly, aprendiendo muy bien el árabe en el convento de Ain-Uarca, idioma sobre el que escribió un Estudio sobre el mecanismo de la lengua árabe (1865). Además, por ausencia de sus titulares, ocupó como suplente en dos ocasiones el consulado de España en Jerusalén hasta 1866. A la marcha de Bernal de O'Reilly, fue nombrado vicecónsul en Beirut entre marzo y junio de 1867. Destinado como vicecónsul en Colombo, Ceilán, hasta noviembre de 1868, donde aprendió singalés, fue nombrado vicecónsul en Damasco, puesto al que se incorporó en agosto de 1869 (Saavedra, 1882: 497-499, 510; Escribano, 2005: 790, 792). Esto motivó un largo viaje por el que recorrió Mesopotamia, describiendo Babilonia, Nínive, Nimrud y Khorsabad en su libro Viaje de Ceilán a Damasco. Golfo Pérsico. Mesopotamia. Ruinas de Babilonia, Nínive y Palmira (1871).

En julio de 1870 fue cesado, durante la regencia del general Serrano en el Sexenio Revolucionario. Nombrado vicecónsul en Teherán el 28 de mayo de 1873 , donde se incorporó en abril de 1874, permaneció aprendiendo persa durante 5 meses, lo que le permitió explorar el país durante casi un año hasta agosto de 1875, cuando regresó a España por mala salud, siendo suprimido el viceconsulado en el mes de noviembre (Saavedra, 1882: 499; Escribano, 2005: 792), sintomático de la nueva etapa que se iniciaba con la Restauración, lo que le permitió redactar Viaje al interior de Persia (1880). Lamentablemente, murió joven en 1882 a los 40 años, después de haber sido cónsul de tercera clase en Singapur y Mogador (Marruecos).

\section{DESAMORTIZACIÓN Y LA CREACIÓN DE LAS Comisiones Provinciales de Monumentos Históricos y Artísticos}

La desamortización de bienes eclesiásticos comenzó durante el reinado de Carlos IV, entre 1798-1808, cuando Godoy vendió bienes de obras pías y beneficencia por valor de 1.653 millones de reales para reducir el déficit público (Tortella, 1981: 34 cuadro 1; Fontana, 2007: 181) y tratar de aumentar las tierras en cultivo debido a la insuficiente producción de grano.

Las Cortes de Cádiz aprobaron un decreto de desamortización el 13 de septiembre de 1813 que inclúa conventos y monasterios suprimidos o destruidos en la Guerra de la Independencia, bienes confiscados a los afrancesados y la mitad de los baldíos y realengos, aunque no se aplicó por la vuelta a la monarquía absolutista de Fernando VII, pero comenzó durante el Trienio Liberal entre 1820-23 con unos 100 millones de reales.

Al final del reinado de Fernando VII, en abril de 1832, el Ministro de Hacienda, López Ballesteros pedía dimitir, sintiéndose incapaz "de detener la bancarrota que está más cercana de lo que muchos creen". En diciembre de 1833, al iniciarse el primer gobierno de la Regencia de María Cristina de Borbón, el Ministro de Hacienda, Antonio Martínez, que duró 3 meses, sólo disponía de 37.000 reales (Fontana, 2007: 136-137, 140), habiéndose multiplicado por cinco la deuda pública entre 1788 con 2.000 millones de reales a más de 10.000 millones en 1833, que exigían anualmente unos 500 millones de reales anuales de intereses y amortizaciones (Fontana, 2007: 232).

La desamortización de Juan Mendizábal, aprobada el 19 de febrero de 1836, afectó a los bienes de las órdenes religiosas monásticas o clero regular, en parte abandonados por motivo de la guerra carlista. El objetivo era sanear la Hacienda Pública y poder pagar la guerra civil contra los carlistas. Las ventas entre 1836-41, con ingresos de 1.700 millones de reales (Tortella, 1981: 33-34), fueron muy similares a la precedente de Godoy.

En 1841, Espartero amplió el decreto el 2 de septiembre, incluyendo los bienes del clero secular, y en sólo 3 años, hasta 1844, se vendieron propiedades por valor de 1.750 millones de reales y unos 1.000 millones se siguieron vendiendo hasta 1851 , sumando en total $3 / 5$ partes de los bienes de la iglesia, 3.100 millones de fincas del clero regular $\mathrm{u}$ ordenes. Además se vendieron 800 millones de fincas del clero secular, cuyas ventas se pararon desde 1844, y 600 millones de censos y foros (Tortella, 1981: 35, 34 cuadro 1; Fontana, 2007: 182). Con estas ventas se redujo a casi la mitad la deuda del Estado, al haberse destinado 5.000 millones de reales a la deuda pública que implicaban 250 millones anuales de intereses y amortizaciones, mientras otros 500 millones fueron destinados a gastos corrientes para disponer de efectivo (Fontana, 2007: 183).

El acontecimiento más importante, porque provocó la creación de las Juntas Científico-Artísticas Provinciales y de los primeros museos provinciales fue la desamortización del patrimonio eclesiástico secular. Este proceso exigió rápidas soluciones para tratar de minimizar importantes pérdidas del patrimonio artístico y bibliográfico de los conventos.

El proceso se inició con la reactivación, el 29 de julio de 1835, del decreto de desamortización vigente en el Trienio Liberal, encargándose a los jefes políticos, actuales gobernadores civiles, de nombrar una comisión de 3 a 5 personas para "examinar, inventariar y recoger cuanto contengan los archivos, bibliotecas de los monasterios y conventos suprimidos, y las pinturas, objetos de escultura u otros". Los miembros de las comisiones se ele- 
girían preferentemente entre los correspondientes de la Real Academia de la Historia, Real Academia de Bellas Artes de San Fernando, Academias de Bellas Artes de Valladolid, Zaragoza y Valencia, Reales Sociedades de Amigos del País o encargados de los archivos públicos, "inteligentes en literatura, ciencias y artes". Esto se reguló el 27 de mayo de 1837 cuando se crearon las Juntas CientíficoArtísticas en cada capital de provincia presididas por el Jefe Político y compuesta por 5 personas elegidas por él, preferentemente de miembros de las instituciones antes citadas, sin embargo, ya había comenzado la venta y exportación de obras de arte, lo que trató de prohibirse en sucesivas Reales Ordenes, demostración que no estaban funcionando adecuadamente, el 2 y 4 de septiembre de 1836, el 27 de abril de 1837, 27 de mayo de 1837 y el 20 de agosto de 1838 (Tortosa y Mora, 1996: 199 n. 48; Maier, 2008: 20-22). Un referente contemporáneo fue la creación de las Comisiones de Monumentos en Francia también en 1837.

Pronto se advirtió la dificultad de tener un catálogo centralizado de edificios, obras de artes, libros, manuscritos y antigüedades recuperadas, por lo que las Juntas Científico-Artísticas Provinciales (1837-44) fueron reorganizadas como Comisiones Provinciales de Monumentos Históricos y Artísticos por Real Orden el 13 de junio de 1844, al iniciarse la Década Moderada y acceder a la Presidencia del Gobierno, Ramón María Narváez Campos. Las comisiones eran dependientes de la Real Academia de Bellas Artes de San Fernando, pero fueron financiadas por las diputaciones provinciales. Se iniciaron las declaraciones de Monumentos Nacionales a partir de la Catedral de León el 25 de agosto de 1844 (Ganau Casas, 1999: 49). Primero dependieron del Ministerio de Gobernación de la Península, dirigido por Pedro José Pidal Carniado, a la que debían informar cada 3 meses. Posteriormente, también en la Década Moderada, bajo Presidencia de Gobierno de Carlos Martínez de Irujo, Duque de Sotomayor, fueron transferidas al Ministerio de Comercio, Instrucción y Obras Públicas el 28 de enero de 1847, que desde el 29 de octubre de 1851 pasó a denominarse Ministerio de Fomento, al entrar como ministro Mariano Miguel de Reinoso.

En todo caso, sus miembros carecían de autorización para realizar excavaciones arqueológicas que debían ser autorizadas por el Gobierno, pero ya se ordenaba, en el artículo 3, de informarse de las "antigüedades que existan en sus respectivas provincias y que merezcan conservarse" y "Formar catálogos, descripciones y dibujos de los monumentos y antigüedades que no sean susceptibles de traslación o que deban quedar donde existen" (Lavín, 1999: 15).
El principal objetivo en 1844 fue la creación de una Comisión Central, que coordinara las Comisiones Provinciales, presidida por el Ministro de Gobernación, Pedro José Pidal Carniado, un vicepresidente, Serafín María de Sotto -Sutton-, Conde de Clonard, y un secretario, el único con sueldo, el cual llevaba el peso de la Comisión Central, que recayó en José Amador de los Ríos, más 5 vocales, Martín Fernández de Navarrete, José de Madrazo, Antonio Gil de Zárate, Valentín Carderera y Aníbal Álvarez. La organización de las Comisiones Provinciales fue bastante parecida, siguió siendo presidida por el Jefe Político y compuesta por 5 personas, 3 nombrados por el Jefe Político y 2 por la Diputación Provincial (Huici, 1990: 122-123), pero siguiendo los criterios de cualificación precedentes.

Sin embargo, el gobierno español dejó de pagar intereses por la deuda desde 1836, y en 1851, Juan Bravo Murillo, Presidente del Consejo y Ministro de Hacienda entre 1851-52, ante una deuda pública que había crecido de nuevo hasta 15.635 millones de reales, hizo una reducción no pactada de los intereses rebajándola hasta 9.609 millones de reales, que hundió el valor de la deuda española, pues dejó de comprarse en las bolsas de Londres, Frankfurt y Amsterdam, quedando sólo la alternativa de los bancos franceses y la colocación de deuda en el mercado interno (Fontana, 2007: 232-233).

Esta situación forzó a la continuación del proceso de desamortización al entrar Pascual Madoz Ibáñez como Ministro de Hacienda, durante 6 meses en 1855, en el último gobierno del Bienio Progresista. Ahora, el grueso de los bienes vendidos fue de los ayuntamientos, con menor protagonismo de la iglesia. Así entre 1855-67, salvo su interrupción entre 1856-58, se vendieron 2.158 millones de reales de bienes de los ayuntamientos, 1.577 millones de la iglesia y 628 de la beneficencia. El proceso de ventas continuó hasta 1900, aunque el porcentaje principal fue entre 1867-76, con 1.415 millones de los ayuntamientos, 888 de la iglesia y 327 millones de la beneficencia (Tortella, 1981: 35, 34 cuadro 1). De ellos, 1.300 millones de reales fueron destinados a pagar las subvenciones para la construcción de ferrocarriles (Fontana, 2007: 280). Los más perjudicados fueron los campesinos pobres que aprovechaban las tierras comunales como zonas de pasto y leña, lo que provocó el descenso de la cabaña ganadera, menores rendimientos por falta de estiércol, pérdida de calidad de la dieta al comer muy poca carne, incremento de la desforestación, etc.

El funcionamiento de la Comisión Central de Monumentos Históricos y Artísticos no fue el deseable y fue suprimida el 9 de septiembre de 
1857, 13 años después, en el artículo 161 de la Ley de Instrucción Pública, al volver al poder sus creadores, Narváez a Presidencia del Gobierno y Pidal al Ministerio de Estado y Ultramar, quedando las Comisiones Provinciales bajo la supervisión de la Real Academia de Bellas Artes de San Fernando.

Para mejorar su funcionamiento se creó el 4 de julio de 1864 una Comisión Mixta Organizadora de las Provinciales de Monumentos, con sede en Madrid, donde participaban 3 miembros de la Real Academia de la Historia y 2 de la Real Academia de Bellas Artes de San Fernando. Debe tenerse en cuenta que muchas veces los académicos elegidos eran miembros de ambas. Así, en 1864 figuraban por la de Historia, Antonio Delgado, Modesto Lafuente y Carlos Ramón y Fort, y por Bellas Artes, Amador de los Ríos y Narciso Pascual Colomer (Maier, 1998: 30-31, 47). Como puede observarse, en la de Historia se eligieron dos directores de la Escuela Superior de Diplomática, Lafuente y Delgado, pero pronto quedó desasistida pues Lafuente falleció en 1866 y Delgado trasladó su residencia a Huelva a finales de 1865 , por lo que el nuevo Reglamento de las Comisiones Provinciales de Monumentos fue redactado por Amador de los Ríos y Ramón y Fort, siendo aprobado el 24 de noviembre de 1865 .

El cambio más significativo en el Reglamento de las Comisiones Provinciales, de noviembre de 1865 , fue que pasaron a representar a ambas academias en el ámbito provincial. Como indica su artículo 4, "Las comisiones provinciales de monumentos históricos y artísticos, así reorganizadas, son inmediatas representantes de las expresadas Reales Academias de San Fernando y de la Historia". Las Comisiones eran presididas por el Gobernador Civil de la provincia, la vicepresidencia recaía en el Correspondiente más antiguo de una de las dos academias, la secretaría en el más joven, y tres puestos de vocales en los restantes correspondientes. En el nuevo Reglamento se otorgaba a sus miembros en el artículo 17 la dirección de "todas las excavaciones arqueológicas que en cada provincia se considerasen necesarias para la ilustración de la historia nacional", una vez autorizadas por el Gobernador Civil y en particular por la Real Academia de la Historia, en la que recaía, según el artículo 23, la inspección de "todas las antigüedades descubiertas y que se descubrieran en el reino". Además, según el articulo 25, "Ninguna Comisión podrá proceder a ejecutar excavaciones sin el previo conocimiento y aprobación de la Real Academia de la Historia". Por otra parte, se establecen excavaciones arqueológicas preventivas, bien cuando se realicen obras públicas que pudiesen afectar a "despoblados antiguos, en las inme- diaciones de grandes vías romanas o en cualquier lugar que ofrezca indicios de construcciones respetables, para evitar la destrucción de los restos arqueológicos", o bien en monumentos en ruinas, antes de su posible restauración, realizando "reconocimientos facultativos y arqueológicos de los monumentos públicos para precaver su ruina y evitar malas restauraciones" (Maier, 1998: 31, $32 \mathrm{n}$. 58; Lara Escoz, 2007: 71).

Otro aspecto importante fue la potenciación de las prospecciones para realizar una catalogación de los yacimientos arqueológicos, señalando el artículo 28 la "formación de un catálogo de despoblados que en cada provincia existieren". Este catálogo de despoblados, que indicaban los yacimientos más importantes donde podían realizarse excavaciones arqueológicas, fue ordenado por la Dirección General de Instrucción Pública a inicios de junio de 1868 (Maier, 2003b: 309), para que en un plazo de 3 meses cada Comisión Provincial de Monumentos entregase "un catálogo de despoblados donde deberían hacerse excavaciones".

Esta medida iba asociada a la aprobación de un Plan General de Excavaciones, solicitado por el Gobierno a la Real Academia de la Historia por Real Orden el 15 de abril, que fue discutido el 24 de abril, encargado a Amador de los Ríos como presidente de la Comisión de Antigüedades el 27 de abril e informado el 8 de mayo de 1868 por el Anticuario, Aureliano Fernández-Guerra, el director de las excavaciones de Numancia, Eduardo Saavedra y Manuel Oliver y Hurtado, cuyo objetivo último era "introducir cierta regularidad en el movimiento que por todas partes se advierte respecto de estas exploraciones arqueológicas" (Maier, 1998: 31 y 2008: 307-308).

Parte del dinero fue aprobado pues se libraron por Real Orden a las respectivas Comisiones Provinciales de Monumentos, 8.000 escudos para excavaciones en Itálica el 19 de febrero de 1868, de los 35.000 escudos previstos, cuadruplicando los 8.000 escudos de $1867 ; 2.000$ escudos para la excavación de La Alcazaba de Granada, donde se creía estaba el foro de la ciudad romana y en Sierra Elvira en septiembre de 1868; 1.000 escudos para la excavación de Augustóbriga en Soria en septiembre de 1868; 600 escudos para la excavación en el Castillo de Montesa e Iglesia de San Félix en Játiva, Valencia, en mayo de 1868; 461 escudos para la excavación en el teatro romano de Mérida en septiembre de 1868; y 400 escudos para las excavaciones destinadas a localizar la batalla de Munda en Córdoba por Luis Maraver en febrero de 1868 (Maier, 2008: 79-80, 304-306, 308, 311-312; Maier et alii, 2000: 203; Luzón, 1999: 94), todas antes del inicio del Sexenio Revolucionario el 30 de septiembre de 1868. 


\section{Primeros museos provinciales}

Antes del proceso de desamortización de Juan Mendizábal, en febrero de 1836, se empezaron a crear museos específicamente arqueológicos, como el Museo Arqueológico de Sevilla (1835) para conservar las colecciones de Itálica.

En Barcelona, con el inicio de los primeros derribos de conventos, ya la Real Academia de Buenas Letras había creado un Museo de Antigüedades en 1835 (Remesal, Aguilera y Pons, 2000: 50, 207-208).

Los hallazgos de la Cantera del Puerto de Tarragona forzaron la creación del Museo Arqueológico de Tarragona (1836), el cual fue solicitado por el Jefe Político de Tarragona en marzo de 1834 al Rey y en enero de 1835 al Ministerio de Gobernación, pidiendo apoyo en febrero de 1835 a la Real Academia de la Historia. El ministerio autoriza el 13 de julio al Ayuntamiento de Tarragona a destinar fondos para el Museo de Antigüedades, cuya sede fue desde 1838 los bajos de la antigua Audiencia (Remesal, Aguilera y Pons, 2000: 56-57, 199).

La Real Academia de la Historia también defendía, en febrero de 1836, en relación con Mérida, pero generalizándolo para todo el reino, la creación de museos provinciales o locales, sugiriendo al Gobierno "incluir una partida con este fin en los presupuestos generales" (Maier, 2008: 120).

Vinculado a la creación desde el 27 de mayo de 1837 de las Juntas Científico-Artísticas en cada capital de provincia, cabe relacionar la fundación del Museo Arqueológico de Mérida el 26 de marzo de 1838, donde se depositaron los materiales procedentes de las excavaciones en Mérida desde 1836.

Por otra parte, los fondos bibliográficos y artísticos de los conventos desamortizados sirvieron para crear las primeras bibliotecas y museos de bellas artes y arqueológicos provinciales. Se especificaba también en el artículo 3 de la Real Orden de 13 de junio de 1844 sobre las Comisiones Provinciales de Monumentos Históricos y Artísticos, la necesidad de "Reunir los libros, códices, documentos, cuadros, estatuas y demás objetos preciosos, literarios y artísticos pertenecientes al Estado que estén diseminados, reclamando los que hubieren sido sustraídos" y "Cuidar los museos y bibliotecas provinciales, aumentar estos establecimientos, ordenarlos y formar catálogos metódicos de los objetos que encierran" (Lavín, 1999: 15). En este proceso cabe incluir la creación del Museo de Bellas Artes de Córdoba (1844), el Museo de Orense (1845), el Museo Provincial de Antigüedades o Arqueología de Oviedo (1845), que no se abrió hasta 1875 en su sede de la Capilla de la tercera orden de San Francisco, solicitada desde 1846, cedida nominalmente en 1860 y entregada en 1868 (Adán, 1999: 176-178) y el Museo de Gerona (1846) (Remesal, Aguilera y Pons, 2000: 53 n. 232), que se instaló desde 1857 en el Monasterio desamortizado de los benedictinos de Sant Pere de Galligants.

Un fenómeno parecido sucedió también en Portugal donde fueron extinguidas las órdenes religiosas en 1834, creándose incluso desde 1833 el Museo Portuense en Oporto, con sede en el Convento de San Antonio, en el cual también fueron depositándose las obras de arte religiosas.

Después de la Desamortización de Madoz continuó la fundación de museos provinciales, entre los que cabe citar el Museo Arqueológico de Lérida (1864), vinculado al Instituto de Estudios Ilerdenses, con sede en el Convento desamortizado del Roser, que ya venía funcionando como sede de un Museo de Antigüedades desde 1847, por el empuje del cronista de la ciudad y periodista, Joaquín Ballester, con la colaboración del médico Jaume Nadal, el Correspondiente de la Real Academia de la Historia y catedrático de Instituto, Josep Pleyán de Porta y de Lluís Roca Florejachs (Lara Peinado, 1969-70; Remesal, Aguilera y Pons, 2000: 54).

\section{REFORMAS UNIVERSITARIAS Y ATENEOS}

Durante el último gobierno de Carlos IV, el Ministro de Gracia y Justicia, José Antonio Caballero Campo-Herrera, Marqués de Carballero, emitió un decreto el 5 de julio de 1807 para reducir el número de universidades en España, en particular las dependientes de la iglesia y los colegios. Esto provocó la extinción de 10 universidades en Irache (Ayegui, Navarra), Oñate (Guipúzcoa), Ávila, Sigüenza (Guadalajara), Toledo, Almagro (Ciudad Real), Gandía (Valencia), Orihuela (Alicante), Baeza (Jaén) y Osuna (Sevilla). Pudieron continuar las de Santiago, Oviedo, Salamanca, Valladolid, Alcalá de Henares (Madrid), Huesca, Zaragoza, Cervera (Lérida), Valencia, Granada y Sevilla (Jiménez Fraud, 1971: 292-293). La Universidad de La Laguna (Tenerife), creada el 11 de marzo de 1792, sufrió vaivenes hasta su consolidación por Real Decreto de Fernando VII el 16 de septiembre de 1816, siendo inaugurada el 12 de enero de 1817 (Núñez Muñoz, 1986: 20-23).

Con el Plan Caballero, en 1807 se crearon las facultades de Filosofía, pero sólo se cursaban 3 años y otorgaban un grado de Bachiller en Artes, el primer año de Lógica, el segundo de Física y el ter- 
cero de Ética y Metafísica. Este grado permitía el acceso a las facultades de Leyes, Cánones, Medicina y Teología, que se cursaban durante 3 años más para alcanzar el grado de Licenciado y un cuarto año para el grado de Doctor.

Durante el Trienio Liberal del reinado de Fernando VII, las universidades de Cervera y Alcalá fueron trasladadas respectivamente a Barcelona y Madrid, denominada Central, el 21 de junio de 1821 (Jiménez Fraud, 1971: 302), creándose también la Dirección General de Instrucción Pública, siendo el Ministro de Gracia y Justicia, Vicente Cano-Manuel Ramírez de Arellano.

También se creaban en 1821 universidades centrales en América, en las ciudades de México, Lima (Perú) y Santa Fé de Bogotá (Colombia) (Jiménez Fraud, 1971: 303). Las universidades de Cervera y Alcalá regresaron de nuevo a sus emplazamientos originarios al restablecerse el poder absolutista de Fernando VII el 27 de mayo de 1823.

Desde 1830, durante más de dos cursos académicos, se suspendieron las clases y permanecieron cerradas las universidades ante el miedo de una propagación revolucionaria desde Francia, aunque siguieron examinando (Jiménez Fraud, 1971: 308; Artola, 1973: 328).

Con la Regencia de María Cristina de Borbón, el 29 de octubre de 1836, se trasladó de nuevo la Universidad de Alcalá a Madrid, primero las facultades de Leyes y Cánones y en 1837 las facultades de Filosofía y Teología. Ese mismo año se suprimió la Universidad de Cervera que se trasladó a Barcelona (Jiménez Fraud, 1971: 308-309).

Con el Plan Pidal (1845) se introdujeron los estudios de historia en la Facultad de Filosofía, siendo el Ministro de Gobernación, Pedro José Pidal y Carniado (1845) y el Director de Instrucción Pública, Antonio Gil y Zarate. Ese año de 1845 se suprimió la Universidad Sertoriana de Huesca, creada en 1354 por Pedro IV de Aragón.

Ventura González Romero, Ministro de Gracia y Justicia entre 1851-52, bajo la presidencia de Bravo Murillo, durante la Década Moderada, creó la asignatura de Arqueología, Numismática y Paleografía el 10 de septiembre de 1852, en el cuarto curso de Filosofía, pero la crisis de gobierno del 14 de diciembre, entrando como nuevo Presidente de Gobierno, Federico Roncali Ceruti, paralizó su aplicación.

La Ley de Instrucción Pública (1857) del Ministro de Fomento con la Unión Liberal, Claudio Moyano y Samaniego, estableció los estudios de enseñanza secundaria, bachillerato o perito mercantil-náutico-agrícola, ampliándose el número de facultades hasta 6, Derecho -la antigua de Leyes-, Medicina, Teología, Filosofía y Letras que pasaron a ser estudios superiores pues antes sólo estaban en el título de Bachiller, más dos nuevas, Farmacia y Ciencias.

Además se reconocían Escuelas Superiores de Arquitectura; Pintura, Escultura y Grabado; Diplomática; Ingenieros Agrónomos; Ingenieros de Caminos, Canales y Puertos; Ingenieros de Minas; Ingenieros de Montes y Notariado.

En la Facultad de Filosofía y Letras los estudios se dividían en 3 años para el grado de Bachiller, con las asignaturas de Historia Universal e Historia de España que se impartían en el $3^{\circ}$ curso. Dos años de Licenciatura, impartiéndose en $4^{\circ}$ y $5^{\circ}$ curso Lengua Hebrea y en $5^{\circ}$ curso Lengua Árabe. El doctorado incluía Lenguas neolatinas, Lenguas teutónicas, Árabe, Estética e Historia de la Filosofía. Esto implicaba que no había ninguna asignatura de especialidad, no ya de Arqueología, sino ni siquiera de Historia, para un Licenciado o un Doctor.

Para atender las iniciativas ilustradas de la burguesía urbana y el déficit de formación ofertada por las universidades comenzaron a aparecer sociedades como ateneos y liceos que canalizaban las corrientes modernizadoras liberales. El Ateneo Científico y Literario de Madrid, fundado durante el Trienio Liberal en 1820-23, tuvo que sobrevivir en el exilio en Londres con la restauración absolutista de Fernando VII entre 1823-33, pudiendo reabrirse de nuevo en Madrid en 1835. En otras ciudades estas iniciativas fueron más tardías, como el Ateneo de Barcelona fundado en 1860 .

El Ateneo de Madrid ofertó docencia en materias que la universidad no ofrecía, caso de de Árabe por Pascual Gayangos (1836-37), Serafín Estébanez Calderón (1837-38, 1842-48) y Francisco Bermúdez de Sotomayor (1838-40); Historia de la Arquitectura Española (1846-47), Historia de las Bellas Artes (1848-49), Historia Universal de la Arquitectura (1849-52), Lengua y literatura sánscrita (1853-54), Arqueología Española (1854-56 y 1858-60) y Lengua céltica (1856-58) por Manuel de Assas (Roca, 1898: 1416; Peiró y Pasamar, 1996: 144 n. 66).

Otro reflejo del interés de las clases medias fue la aparición de revistas no políticas, de divulgación científica, artística y literaria, que presentaban habitualmente artículos de arqueología, como el Semanario Pintoresco Español entre 1836-57, que acabó dirigiendo Manuel de Assas en 1857 y El Museo Universal entre 1857-69. 


\section{La Real Academia de la Historia y la CREación de La Escuela Superior de Diplomática en 1856 Y DEL CUERPo Facultativo de Archiveros Y BiblioteCARIOS EN 1858}

La falta de eficacia en las Reales Academias, y en particular de la Real Academia de la Historia, por la escasez de miembros, hizo que fuese reformada en la Década Moderada bajo presidencia del Gobierno de Carlos Martínez de Irujo, Duque de Sotomayor, por Real Decreto de 25 de febrero de 1847 , donde se fijó un número de 36 miembros, suprimiéndose las categorías de académicos honorarios o la previa de Supernumerario, cuyos miembros fueron ascendidos a Numerarios.

El proceso de sustitución de miembros fallecidos en la Real Academia de la Historia no había sido el adecuado y así de 24 numerarios sólo había 5 y de 25 supernumerarios estaban nombrados sólo 17, aún entre 1847-50, lo que llevó al Ministerio a preguntarse "¿Faltan en España sujetos que merezcan pertenecer a ella? A fe que no, y bien los hallaría tanto o más ilustres que los que la componen, entre los cuales, a la verdad, hay algunos cuyo nombre es bastante obscuro en la república de las letras (...) La Academia de la Historia constituida como lo está hoy da muy pocas señales de vida y menos deseos de organizarse (...) Adolece de todos los achaques de la vejez" (Luzón, 1993: 273).

Estos cambios facilitaron el acceso de algunos jóvenes arqueólogos y orientalistas a la Real Academia de la Historia, lo que les permitió continuar durante la Restauración, Amador de los Ríos (con 30 años), Cánovas (32), Saavedra (33), Fernández y González (34), Gayangos (38), Moreno Nieto (39), Fernández-Guerra (40) o Riaño (41).

La clasificación de los fondos bibliográficos de los conventos desamortizados había generado serios problemas desde $1835-36$, por la ausencia de personas con buena formación paleográfica. Un problema similar había ocurrido en Francia, cuando se tuvo que crear en 1821, la École Nationale des Chartes -Escuela Nacional de Archiveros- en París, para catalogar los fondos confiscados en los conventos durante la revolución de 1789, la cual fue reorganizada en 1846, incluyéndose una asignatura de Arqueología y las Artes de la Edad Media, dentro de la corriente de la Arqueología Monumental.

Durante la Década Moderada, el 22 de octubre de 1852, se inició la solicitud para su creación. Después de una visita de Pascual Gayangos a la Escuela de Diplomática en Portugal se discutió en la Real Academia de la Historia, que encargó al secretario, Pedro Sabau y Larroya y Antonio
Cavanilles el informe sobre la creación de una Escuela de Diplomática para "el conocimiento de los documentos y monumentos de la edad media" donde se impartiese docencia en "historia, la geografía de aquella época, el latín de la baja y bárbara latinidad, la archeologia, numismática y la paleografía", el cual presentaron para su aprobación el 5 de noviembre (Almagro Gorbea y Maier, 1999: 200-202; Maier, 2008: 53, 196-197), aunque su redacción corresponde a Gayangos (Álvarez Millán, 2004: 45). Es interesante observar que en ella no se implica el Anticuario, Antonio Delgado, a pesar que asistió a la reunión. El informe fue remitido al Ministro de Gracia y Justicia, Ventura González Romero, pero el 14 de diciembre dimitió el Presidente del Gobierno, Juan Bravo Murillo, que fue sustituido por Federico Roncali Ceruti y en la cartera de Gracia y Justicia, por Federico Vahey Alba, pero no debió haber un corte brusco porque en enero de 1853 se solicitó también la creación de un Museo Nacional de Antigüedades.

El 20 de junio de 1856 la Real Academia de la Historia volvió a recordar al Gobierno la necesidad de crear una Escuela de Diplomática, y justo después del verano, el 5 de septiembre, el Ministerio de Fomento aprobó el proyecto, encargando informe a la Academia sobre como llevarlo a cabo (Maier, 2008: 212-213), que aprobó el 19 de septiembre un informe elaborado por Pedro Sabau, Antonio Delgado, el Barón de Lajoyosa, el Conde de Canga-Argüelles y Tomas Sancha, en el cual se establecía como requisito para ingresar tener 18 años cumplidos, el título de Bachiller en Filosofía y realizar un examen previo sobre Historia General de España y nociones de Literatura (Almagro Gorbea y Maier, 1999: 202-204).

Un mes después, el 7 de octubre de 1856, se creó de la Escuela Superior de Diplomática, que empezó a impartir docencia en la Biblioteca de la Real Academia de la Historia el 21 de noviembre (Peiro y Pasamar, 1996: 40) y en los Reales Estudios de San Isidro, fundado por los Jesuitas en 1625. Fue aprobado por el Ministro de Fomento y Ultramar, Manuel José Collado Parrada, bajo la presidencia de Leopoldo O'Donnell, al iniciarse la Unión Liberal.

La dirección desde el 9 de octubre de 1856 correspondió a Modesto Lafuente y Zamalloa. Nacido en Rabanal de los Caballeros (León) el 1 de mayo de 1806, falleció a los 61 años en Madrid el 25 de octubre de 1866. Entre 1850-66 redactó 29 volúmenes de la Historia general de España, hasta el reinado de Carlos IV, cuando se interrumpió por su fallecimiento. En 1854 ingresó en la Unión Liberal de O'Donnell, siendo varias veces elegido como Diputado por Astorga (León). 
La promulgación de la Ley de Instrucción Pública del 9 de septiembre de 1857 por el Ministro de Fomento, Claudio Moyano Samaniego, le dio categoría de centro de enseñanza superior en su artículo 47 y sus estudios se estructuraron el 23 de septiembre de 1857 en 3 cursos. El plan de estudios estaba centrado en Paleografía y sólo contemplaba una asignatura de Historia en el tercer curso, Historia de España en los siglos medios, con 3 horas semanales, y otra de Arqueología y Numismática, de la que se impartían 3 horas semanales en segundo curso (Peiró y Pasamar, 1996: 61).

El candidato del Director, Modesto Lafuente, para impartir la docencia de la asignatura de Arqueología y Numismática, era el barcelonés Florencio Janer y Graells, entonces con 25 años y sin ningún artículo científico, como refleja una carta de recomendación de Lafuente al Ministro de Fomento (Romero, 2007: 587). Florencio Janer ingresó pocos años después, en 1861, en el Cuerpo de Archiveros y Bibliotecarios incorporándose a la Biblioteca de la Universidad Central de Madrid. Nombrado Gobernador Civil de Álava en 1866 y Presidente de la Comisión Provincial de Monumentos de Álava, excavó entre 1866-68 en Iruña (Álava). El 1 de agosto de 1868 se incorporó al Museo Arqueológico Nacional hasta su muerte el 19 de julio de 1877 (Ruiz Cabriada, 1858: 489), con sólo 46 años.

Sin embargo, tuvo más fuerza el Ministro de Gracia y Justicia, Joaquín Aguirre, que recomendó a uno de sus ayudantes, Juan de Dios de la Rada y Delgado, que lo sustituía en la Facultad de Derecho como "profesor sustituto "sin retribución"”, en su Cátedra de Derecho Canónico, disciplina general de la Iglesia y particular de España (Peiró y Pasamar, 1996: 69-70). Juan de Dios de la Rada y Delgado fue nombrado Catedrático en comisión para la asignatura de Arqueología y Numismática desde el 18 de noviembre de 1856 y en propiedad desde el 10 de julio de 1858 .

El 29 de agosto de 1858 entró Antonio Delgado, quizás como Director en funciones de la Escuela (Belmonte, 1880/2001: xxxviii), pues su nombramiento por Real Decreto no fue hasta el 29 de agosto de 1860 (Peiró y Pasamar, 1996: 45, 71). Aunque siempre se utiliza la fecha en 1860 , y coincide en ambas el 29 de agosto, no debe olvidarse que Lafuente fue nombrado Vicepresidente del Congreso de los Diputados en 1858 y es posible que comenzase a sustituirlo. La primera fecha fue sólo 2 meses después del nombramiento de Leopoldo O'Donnell como presidente el 30 de junio, cargo en el que continuó hasta 1863, lo que otorgó estabilidad a la institución. El 17 de julio de
1858 se creó además el Cuerpo Facultativo de Archiveros y Bibliotecarios.

El 16 de julio de 1863 se modificó el plan de estudios que consiguió elevar su nivel académico, dividiéndose la asignatura de Arqueología y Numismática en tres nuevas, aumentando así la carga docente de 3 a 9 horas semanales, Numismática antigua y de la Edad Media, y en especial de España, impartida por de la Rada, Epigrafía y Geografía Antiguas y de la Edad Media por Delgado e Historia de las Bellas Artes en los tiempos antiguos, Edad Media y Renacimiento, con la arqueología monumental, impartida por Juan Francisco Riaño y Montero. Sin embargo, las razones de la modificación eran más prosaicas (Peiró y Pasamar, 1996: 71; AGA caja 15057). Riaño había perdido la Cátedra de Teoría e Historia de las Bellas Artes de la Escuela Superior de Pintura, Escultura y Grabado de Madrid en febrero de 1861, porque aunque había quedado el primero en la oposición, el Ministro de Fomento, Francisco de Luxán, eligió al segundo, Juan José Martínez de Espinosa, dejando sin plaza a Riaño. Al entrar como nuevo Ministro de Fomento, Manuel Merino López, éste decidió crear una nueva Cátedra de Historia de las Bellas Artes, de la cual lo nombró el 7 de julio. Esta modificación fue aprovechada por su Director, Antonio Delgado, para incluir una semana después, una asignatura propia que el mismo impartiría, Epigrafía y Geografía Antiguas y de la Edad Media.

Esta fue quizás la mejor etapa de la escuela por el peso que tenía Delgado en la Unión Liberal de O'Donnell, continuando en la dirección hasta su jubilación voluntaria en 1865 , que motivó su sustitución en Epigrafía y Geografía Antiguas por el presbítero malagueño Manuel Oliver Hurtado el 7 de diciembre de 1865 (Peiró y Pasamar, 1996: 72), autor del estudio sobre el emplazamiento de Munda Pompeiana, quien procedía de la Biblioteca Nacional donde había entrado en 1865, después de haber ingresado en el Cuerpo Facultativo en 1861.

\section{EL FRACASO DE LA LEY DE EXCAVACIONES Y Antigüedades POR la Real ACademia de LA Historia}

El Real Decreto del 15 de noviembre de 1854, durante el gobierno en el Bienio Progresista de Joaquín Baldomero Fernández Espartero, sobre las Comisiones Provinciales de Monumentos, les prohibió en su artículo 31 destinar fondos para realizar excavaciones, "no podrán las Comisiones provinciales destinar los fondos consignados en sus presupuestos a las excavaciones y diligencias practi- 
cadas para el descubrimiento de antigüedades y nuevas empresas arqueológicas", aunque se les dejaba abierta la posibilidad en caso de disponer de "sumas sobrantes", previa autorización del Gobierno (Lara Escoz, 2007: 71), en un momento de crisis del erario público, poco antes de la desamortización de 1855.

A finales de la década de los años cincuenta comenzó a hacerse patente la necesidad de regular las excavaciones arqueológicas. Uno de los detonantes fue la solicitud en mayo de 1858 de Jorge Loring Oyarzábal, al que Isabel II le concedió el título de Marqués de Casa-Loring y era uno de los propietarios del Banco de Málaga, a la Dirección General de Instrucción Publica, de autorización para realizar excavaciones arqueológicas en la provincia de Málaga, lo que motivó en respuesta ese mismo mes de la Real Academia de la Historia al Gobierno "la necesidad de que fije en una ley, la forma en que se hayan de hacer los descubrimientos de antiguos monumentos, estableciéndose en ellas el principio y las reglas para evitar las muchas cuestiones que pudieran ocurrir entre el descubridor y los dueños de los terrenos en que se quiera hacer el descubrimiento, la intervención o la inspección, y por último el destino de los objetos hallados (...) y en particular de aquellos que por su importancia histórica o artística sean dignos de conservarse como propiedad nacional en el sitio y lugar que el Gobierno señale, así como los premios e indemnizaciones que hayan de concederse" (Tortosa y Mora, 1996: 203; Salas y Maier, 2003: 184; Maier, 2008: 224).

Durante el gobierno de Leopoldo O’Donnell Joris, el Director General de Instrucción Pública solicitó el 14 de diciembre de 1859 que la Real Academia de la Historia elaborase un Proyecto de Ley de Excavaciones y Antigüedades (Maier, 1998: 30 y 2003a: 45 n. 69), siendo Ministro de Fomento, el Marqués de Corvera, Rafael de Bustos y Castilla-Portugal. Posteriormente fue solicitado de nuevo por el nuevo ministro, Antonio de Aguilar y Correa, Marqués de la Vega de Armijo, el 22 de julio de 1862 y después por el ministro Claudio Moyano Samaniego, el 30 de enero de 1864, sólo 13 días después de su nombramiento.

Dos días después de la primera solicitud, se formó el 16 de diciembre 1859 la comisión de la Real Academia de la Historia por los antiguos miembros que habían redactado las bases del Proyecto de Ley, a los que se sumó un letrado, Pedro Gómez de la Serna, que exigía la Real Orden del 14 de diciembre. Los miembros dedicados al Proyecto de Ley de Antigüedades eran los mismos en enero de 1863, presidida la comisión por Pedro Sabau y Larroya, Secretario de la Real Academia de Historia, en la cual también participaban Antonio Delgado, Pascual Gayangos, José Amador de los Ríos, Antonio Cavanilles, Pedro Pidal, José Caveda, Salustiano de Olózaga, Aureliano Fernández-Guerra y Pedro Gómez de la Serna (Tortosa y Mora, 1996: 204 n. 71; Maier, 2008: 238, 266).

Lógicamente, aparte del letrado Gómez de la Serna (vide infra), uno de los principales responsables de la no remisión del Proyecto de Ley de Excavaciones y Antigüedades fue el Anticuario, Antonio Delgado, cuya edad entre 54 y 63 años entre 1859-68, no puede ser un atenuante y además tenía formación en leyes. La razón creemos que estuvo en su nombramiento como Director de la Escuela Superior de Diplomática entre 1858-65, que le debió absorber buena parte de su tiempo. Ese mismo problema después le pasó a de la Rada cuando fue también director desde 1876. La falta de atención a varios expedientes importantes se aprecia con el expediente de Canarias más extenso en la Real Academia de la Historia, sobre las 4 momias del Barranco de Araya, que estuvo paralizado por las mismas razones desde 1862 hasta 1868 (Jiménez Díez y Mederos, 2001: 109; Mederos, 2003: 203) o como también sucedió con el expediente de Murviedro, actual Sagunto (Mora, Tortosa y Gómez, 2001). Si analizamos las Sesiones de la Real Academia de la Historia, se aprecia que Delgado falta por primera vez en la navidad de 1864-65, pero se reincorporó sólo un mes en junio de 1865 (Maier, 2008: 278-280) y ya dejó de asistir a las reuniones. Ese año de 1865 también se jubiló voluntariamente a los 60 años por enfermedad y se retiró a Bollullos del Condado en Huelva (Belmonte, 1880/2001: xl), siendo nombrado ya un sustituto en su cátedra de la Escuela Superior de Diplomática en diciembre. Reapareció ese mes de diciembre de 1865, para presentar en enero de 1866 el informe anual del Gabinete de Antigüedades, permaneciendo hasta finales de febrero. Nuevamente ausente en marzo y abril, sólo reapareció en mayo, y desde junio ya se comunicó por carta con la Academia (Maier, 2008: 281-283, 285-286). Ausente casi un año, a fines de abril o inicios de mayo de 1867 informó por carta de su renuncia al cargo de Anticuario por enfermedad, eligiendo el Director, Antonio Benavides, como Anticuario interino a Aureliano Fernández-Guerra, el 3 de mayo de 1867.

La potenciación de las excavaciones arqueológicas por el Gobierno se había convertido en una prioridad en este periodo, como demuestra que en 1865 se tenían previsto "200.000 [reales] asignados en el presupuesto de este año para la realización de excavaciones en Numancia, Itálica, Mérida, Murviedro [Sagunto] y otros sitios célebres" (Álvarez Sanchís et alii, 2000: 297). 
La petición del Proyecto de Ley de Antigüedades se volvió a reclamar al acceder Ramón María Narváez Campos a la presidencia del gobierno, quien nombró Ministro de Fomento al Marqués de Orovio, Manuel Orovio Echagüe, y solicitó de nuevo el Proyecto de Ley de Excavaciones y Antigüedades en 6 ocasiones entre 1867-68, el 31 de enero, 15 de febrero, 7 de marzo, 7 de junio, 22 de septiembre y 23 de diciembre de 1867 y 13 de marzo de 1868 (Tortosa y Mora, 1996: 204 n. 72; Maier, 1998: 30 n. 51 y 2003a: 45 n. 69).

Todas estas solicitudes fueron siendo ya Aureliano Fernández-Guerra, Anticuario interino, y además se comentó en sesión del 5 de octubre de 1867 la solicitud por el Director General de Instrucción Pública de una Ley de descubrimientos arqueológicos. El 6 de diciembre se produjo la votación para la elección como Anticuario de Fernández-Guerra (Maier, 2008: 298, 301), que salió frente a las candidaturas de Pascual de Gayangos, que tenía más antigüedad y méritos, pues se jubilaría de su cátedra en 1871, y de Pedro de Madrazo. Es llamativo que la persona más adecuada para el puesto de Anticuario, Amador de los Ríos, que presidía la Comisión de Antigüedades en la Real Academia de la Historia, y quien dos meses después, en febrero de 1868, fue nombrado Director del Museo Arqueológico Nacional, no se presentase, pues tenía más antigüedad también que Fernández-Guerra, pero menos que Gayangos, y es posible que respetase ese criterio.

En sesiones del 25 de septiembre y del 6 de noviembre de 1868 volvió a tratarse el tema por la petición del Director General de Instrucción Pública del Proyecto de Ley de Excavaciones y Antigüedades para que se emitiese "a la mayor brevedad posible" (Maier, 2008: 312-313), lo que implica que hubo dos peticiones posteriores a la citada de marzo de 1868, correspondientes al 18 de julio y 26 de octubre de 1868 (Tortosa y Mora, 1996: 204 n. 72), pero la Academia sólo decidió en la primera que se informase a la comisión de 10 miembros y en la segunda que se le comunicase a Pedro Gómez de la Serna, paradójicamente presente en la reunión, mientras el anticuario, FernándezGuerra, estuvo ausente en esta reunión y las del mes precedente de octubre, incorporándose a mediados de noviembre.

Ambas son importantes porque corresponden la primera al último gobierno con Isabel II, presidido por José Gutiérrez de la Concha Irigoyen, siendo Ministro de Fomento, Severo Catalina del Amo. Y la segunda al primer gobierno durante el Sexenio Revolucionario, presidido por el general Francisco Serrano Domínguez y como Ministro de Fomento, Manuel Ruiz Zorrilla. E implican una continuidad en el intento de regular las excavaciones arqueológicas.
Toda esta serie de comunicaciones se trasladaban por Pedro Sabau y Larroya, Secretario de la Real Academia de la Historia y presidente de la Comisión para la preparación del Proyecto de Ley de Antiguiedades, siempre a Pedro Gómez de la Serna y Tully, y están en la documentación de Granada (Maier et alii, 2000: 199-201), la primera el 16 de febrero de 1867 (la del 31 de enero), la segunda el 11 de enero de 1868 (del 23 de diciembre), el 28 de marzo (del 13 de marzo), el 27 de abril, el 26 de octubre (del mismo 26 de octubre) y el 7 de noviembre, lo que nos descubre otras dos nuevas peticiones gubernamentales en abril y noviembre de 1868 , y la constante siempre fue la ausencia de respuesta por parte del letrado Gómez de la Serna, que falleció el 12 de diciembre de 1871.

Pedro Gómez de la Serna y Tully era una persona muy influyente, pero también muy ocupado entre 1858-68. Elegido Numerario de la Real Academia de la Historia el 6 de junio de 1856, con el apoyo de Sabau, Gayangos, Amador de los Ríos, Lafuente y Cavanilles (Siete Iglesias, 1978: 551). Fue primero Catedrático interino de Derecho Romano entre 1827-28, sobre el que elaboró un excelente trabajo, Curso histórico-exegético de Derecho Romano comparado con el español (1840-50), y en propiedad Catedrático de Instituciones Civiles desde 1829 de la Universidad Central, alcanzando el puesto de Rector (1840). Jefe Político, actual Gobernador Civil, por Guadalajara (1836) y Vizcaya (1840). Diputado por Soria $(1839,1841,1843$ y 1854) y Orense (1846). Subsecretario de Gobernación desde 1842, fue brevemente Ministro de Gobernación de la Península entre el 19 de mayo y el 30 de julio de 1843 y lo aprovechó para crear la Facultad de Jurisprudencia al refundir las previas de Leyes y Cánones. Siendo miembro del Partido Progresista de Mendizábal fue nombrado Ministro de Gracia y Justicia interino desde el 18 de julio de 1854, Fiscal del Tribunal Supremo desde 1855 y después elegido Senador vitalicio en la legislatura 1859-60. Presidente del Tribunal Supremo de Justicia y Consejero de Estado desde 1858 hasta 1871, que le valió ser nombrado Caballero del Toison de Oro en 1870, en la legislatura de 1871-72 volvió a ser nombrado Senador.

Es posible que su relación con ambos anticuarios no fuera buena. Por una parte, al ser propuesta su candidatura en mayo de 1855 que no salió elegido y después en mayo de 1856, no figuró Delgado, siendo propuesto por Gayangos, Amador de los Ríos, Lafuente y Cavanilles (Siete Iglesias, 1978: 551), que claramente indica una ideología liberal progresista. Este aspecto, con seguridad, le distanciaría mucho de Fernández-Guerra, vinculado a los neocatólicos y afectaría a los años 1867-68 
cuando hubo 10 peticiones por parte de los sucesivos gobiernos para que se informase el Proyecto de Ley de Antigüedades.

Paradójicamente, cuando se solicitó por el Gobierno en abril de 1868 que la Real Academia de la Historia informase un Plan General de Excavaciones, discutido el 24 de abril, se emitió resolución en apenas 15 días, el 8 de mayo (Maier, 2008: 307-308)

\section{Basilio Castellanos de Losada Y LA PRI- MERA DOCENCIA EN ARQUEOLOGía Artística Monumental en el Ateneo de MADRID}

La falta de operatividad de la Real Academia de la Historia en el campo de arqueología favoreció el despegue de instituciones que trataron de ocupar competencias que detentaba en exclusiva.

Es llamativo que se aprecie una notable crisis en el Archivo de la Comisión de Antigüedades desde fines de los años treinta, que no se empieza a recuperar hasta avanzados los años cuarenta, sobre la cual Almagro Gorbea (1999: 173 tabla y 2003: 213) sugiere causas políticas y en su fase final a la creación de las Comisiones Provinciales de Monumentos desde 1844, que pudieron actuar independientemente de la Real Academia de la Historia.

Este periodo coincide con la elección como Anticuario del granadino Juan Bautista Barthe entre 1836-48, que carecía de estudios, pero había sido Oficial Mayor de Policía en Sevilla y Regidor en Guadix desde 1829. Nombrado Anticuario interino por sus conocimientos en numismática, de la que tenía una colección personal, cargo al que formalmente no podía ser elegido pues era Supernumerario y no Numerario, renunció en 1848 a favor de su amigo y numísmata, Antonio Delgado, porque se hizo cargo del puesto de Administrador Principal de Correos en Toledo, ya que al final residía en esa ciudad, al punto que tuvo que renunciar a la categoría de Supernumerario por la de Correspondiente en mayo de 1850 (Almagro Gorbea, 1999: 139). Fue, desde nuestro punto de vista, la no idoneidad de la persona elegida como Anticuario, lo que motivó la decadencia de la actividad del Gabinete de Antigüedades. Un fenómeno similar volvió a ocurrir durante la Restauración con la elección del literato Aureliano FernándezGuerra y Orbe (Mederos, e.p.).

Su demostración está en que en estos años, Castellanos de Losada creó la Sociedad Numismática Matritense (1837-39), luego Sociedad Arqueológica Matritense y Central de España y sus Colonias (1839-44), después
Academia Española de Arqueología por Real Orden de 5 de abril de 1844, Academia Española de Arqueología y Geografía a partir del 3 de junio de 1860 y finalmente Academia Real de Arqueología y Geografía del Príncipe Alfonso (1863-68), al ser elegido el Príncipe Alfonso, futuro Alfonso XII, como su protector, concediéndole el 3 de julio de 1863 el título de Real. En su fundación, el 1 de abril de 1837, participaron Castellanos de Losada, Francisco Bermúdez de Sotomayor, Pedro González Mate y Nicolás Fernández, siendo su corresponsal en Londres, Pascual de Gayangos. Su estrecha vinculación con Castellanos queda evidente en que sus lugares de reunión hasta 1863 fueron inicialmente la Biblioteca Nacional en cuyo Gabinete trabajaba desde 1834 y posteriormente en la Escuela Normal de Instrucción Primaria que dirigió entre 1856-68 (Calle, 2004: 126, 128; Roca, 1898: 73 n. 2).

Basilio Sebastián Castellanos de Losada nació el 14 de junio de 1807 y falleció el 1891, dentro del seno de una familia muy humilde de Madrid, hijo de Benigno Antonio Castellanos y Serrano de La Solana, de Ciudad Real, y de Francisca Losada de Castro de Morata de Tajuña, en Madrid. Fue el hermano mayor de otros 3 chicos a cuya manutención contribuyó para que fuesen al Colegio Militar y eran jóvenes oficiales en el ejército de Isabel II en 1839. En su caso, fue entregado por sus padres para servir como paje del Arzobispo de Tiro, Giacomo Giustiniani, Nuncio del Papa en Madrid, marchando a Nápoles y Roma, para así costear su educación. En 1822, a los 15 años, regresó a España durante el Trienio Liberal, asistió a clases de francés e italiano en el Ateneo de Madrid, y luchó junto a los liberales en 1823, como también hizo Antonio Delgado, siendo encarcelado hasta el 30 de enero de 1824. Exiliado en Italia, debió conocer en Roma al arqueólogo clásico Antonio Nibby, estando aparentemente algún tiempo al servicio de María Cristina de Borbón y Dos Sicilias, sobrina de Fernando VII. También debió tener contactos en la Reale Accademia Hercolanense de Nápoles, que años después, en 1852, lo eligió Académico de Honor. En 1826 residió en Barcelona, ciudad donde estudió algo de alemán y hebreo. Entre 1827-28 aprobó los exámenes de maestro y para la enseñanza de italiano y francés. Se incorporó a la comitiva real cuando María Cristina de Borbón y Dos Sicilias vino a España a casarse en 1828 como cuarta mujer de Fernando VII, impartiendo clases de francés e italiano en el Colegio de Escuelas Pías de San Fernando (Sánchez Bidema, 1868; Ruiz Cabriada, 1958: 208; Lavín, 1997: 250-251).

Como puede observarse, Castellanos de Losada no pasó de un grado de Bachiller, con estudios de 3 años, no cursando los de Licenciado y el último 
año de Doctorado, por lo que fue infravalorado por los académicos de la Real Academia de la Historia, de la que pronto se convirtió en un competidor en el ámbito de la arqueología.

Al iniciarse la Regencia de María Cristina de Borbón fue nombrado en 1833 escribiente en la Biblioteca Nacional y en 1834 lo destinaron al Gabinete de Antigüedades y Monetario, que se encargó de reorganizar, pues estaban desordenados desde su traslado de la anterior sede en la calle del Almirantazgo, entre 1818-26. Por este trabajo y la redacción de la Galería Numismática Universal (1838-39), fue nombrado, en 1839, Anticuario Conservador del Gabinete de Antigüedades y del Museo de Medallas o monetario de la Biblioteca Nacional (Gómez Pérez, 1958: 561).

Ya entonces era patente el daño que había hecho la Guerra de la Independencia y la crisis durante el reinado de Fernando VII, como le comenta Castellanos a Gayangos en 1835, "los extrangeros son mas curiosos e ilustrados en estas materias $\mathrm{q}[\mathrm{u}]^{\mathrm{e}}$ nosotros $\mathrm{q}[\mathrm{u}]^{\mathrm{e}}$ nos hallamos por desgracia en la infancia de todo lo bueno. Espero q[u]e no olvide V. q[u]e estoy deseoso de poseer alguna obra de Numismática moderna, y q[u]e aquí no es fácil satisfacer este deseo" (Vilar, 1984: 164). Sin embargo, por el coleccionismo existente, la numismática era también una vía de obtener ingresos paralelos como le reconocía Castellanos a Gayangos en una carta de 1839, "No se hace venta de medallas ó antiguallas (...) que no sean previamente tasadas por mí" (Roca, 1898: 73).

Basilio Castellanos comenzó a impartir la cátedra de Arqueología en el Ateneo de Madrid desde el 10 de noviembre de 1837 hasta 1839, primero los domingos, después la noche de los miércoles y luego los jueves. En el curso 1839-40 fue de Numismática aplicada a la legislación española los miércoles por la noche y en el curso 1840-41 de Elementos de historia y arqueología universal los martes (Roca, 1898: 17 n. 1). Esta docencia la simultaneo con la cátedra de Numismática en el Liceo Artístico y Literario de Madrid, en el curso 1838-39. Y de Arqueología, "por medio de la Numismática", en el Colegio Universal de Humanidades, fundado por Sebastián de Fábregas en 1837, también en el curso 1838-39. En 1839, al crearse el Instituto Español, por el Marqués de Sauli, pasó a impartir también Arqueología. Con semejante carga docente, en 1838 Castellanos volvió a escribir a Pascual de Gayangos pidiéndole auxilio para conseguir libros básicos sobre arqueología y numismática (Roca, 1898: 17-18 n. 1).

Ascendido a Bibliotecario de la Biblioteca Nacional el 30 de junio de 1847, permaneció en ella hasta que fue nombrado, el 4 de diciembre de
1856, Director de la Escuela Normal de Instrucción Primaria, hasta 1868 en que fue suprimida la Escuela, impartiendo clases voluntarias de Arqueología, Historia de España e Historia Universal y Geografía (Lavín, 1997: 251, 254). Durante este periodo también desempeñó la Cátedra de Arqueología del Ateneo de Madrid en 1848-49 (Berlanga, 2001: 19), siendo quien redactó el primer manual de arqueología en español, el Compendio elemental de Arqueología (1844-45), cuyo tercer volumen publicó después independientemente como Arqueología Artística Monumental (1845). Parece haberse presentado como candidato a Diputado con el Partido Progresista (Ruiz Cabriada, 1958: 209) de Espartero, pero no sabemos que haya sido elegido.

\section{El Gabinete de Antigüedades Y DEL Museo de Medallas de la Biblioteca NACIONAL, ORIGEN DE LAS COLECCIONES del Museo ArQueológico Nacional}

La importancia del Gabinete de Antigüedades y del Museo de Medallas de la Biblioteca Real, Biblioteca Nacional desde 1826, como origen de las colecciones del Museo Arqueológico Nacional a veces no se ha tenido suficientemente en cuenta, ya que conformó la base del nuevo museo. Esta institución sufrió tres traslados en poco menos de 20 años, primero al Convento de la Trinidad por José Bonaparte en 1809, luego a la Casa del Almirantazgo en 1818 y finalmente en 1826 a la casa $n^{\circ} 4$ de la Plaza de Oriente. Su colección monetaria ya tenía en 1835, cuando entró Castellanos, 2.672 monedas de oro, 30.669 de plata y 51.183 de bronce. En el catálogo que redactó en 1846, Inventario de las monedas y medallas del Museo de la Biblioteca Nacional, la colección había aumentado hasta 2.292 monedas de oro, 33.552 de plata, 54.097 de bronce y 1.006 en plomo (Alfaro, 1993: 148-149). A ellas se unían casi 900 piezas arqueológicas entre las que destacaban 61 bronces (Hübner, 1862/2008: 214-225), 8 vasos griegos (Hübner, 1862/2008: 208-210) y 10 mosaicos romanos (Hübner, 1862/2008: 210-214). El Museo Arqueológico Nacional además recibió en 1867 unas 3.000 piezas arqueológicas y etnográficas presentes en el Museo de Ciencias Naturales, procedentes de la antigua Sala de Antigüedades del Real Gabinete de Historia Natural, creado por Carlos III cuando compró en 1777 la colección de Pedro Franco Dávila, y el modesto monetario de la Escuela Superior de Diplomática, de escasa importancia, pues eran monedas utilizadas para prácticas con los alumnos (Marcos Pous, 1993: 37-38).

Por esta circunstancia, al transformarse el Gabinete de Antigüedades y del Museo de 
Medallas de la Biblioteca Nacional en el Museo Arqueológico Nacional, Castellanos de Losada fue nombrado oficial de primer grado en el Cuerpo de Archiveros y Bibliotecarios por Real Orden el 10 de abril de 1867 (Alfaro, 1993: 150; Lavín, 1997: 251), pero no figura en los miembros de la plantilla al constituirse el museos que recoge Marcos Pous (1993: 43), aunque la considera una lista provisional, porque seguía de Director de la Escuela Normal de Instrucción Primaria, del que fue cesado en 1868. Sin embargo, no parece haber podido incorporarse al museo porque en la plantilla de octubre de 1870 (Marcos Pous, 1993: 58) sigue sin figurar. En todo caso, su traslado al Museo Arqueológico Nacional en 1867, siendo oficial de primer grado, no necesariamente supone una reducción de categoría como sugiere Lavín (1997: 251), y habría que ver si hubo una reducción significativa de sueldo, pues era el nivel que tenía Ventura Ruiz Aguilera cuando fue nombrado director del Museo Arqueológico Nacional en 1868 (Marcos Pous, 1993: 58) y además se integraba por primera vez en el Cuerpo de Archiveros y Bibliotecarios, sección de Museos, que se había creado desde julio de 1858. Con la Restauración pudo reincorporarse, siendo nombrado conservador de numismática del Museo Arqueológico Nacional (1876-85), del que llegó a ser Director (1886-91).

\section{La Academia Española de Aroueología}

La Academia Española de Arqueología disponía en 1844, de una enorme difusión por España, que revela el interés por la arqueología y un futuro análisis concreto de cada una de sus diputaciones provinciales será la clave para comprender la difusión de la arqueología en España entre la pequeña burguesía. Se conoce que contaba con 33 sociedades distribuidas en Galicia (La Coruña, Santiago de Compostela, Lugo, Orense), Oviedo, Santander, País Vasco (Bilbao, Guipúzcoa), Navarra, Aragón (Huesca, Zaragoza), Cataluña (Gerona, Lérida, Barcelona), Castilla-León (Valladolid, Burgos, Segovia), Castilla-La Mancha (Toledo, Ciudad Real, Cuenca), Badajoz, País Valenciano (Valencia, Alicante), Mallorca, Murcia, Andalucía (Granada, Jaén, Córdoba, Sevilla, Cádiz), Canarias, Cuba y Filipinas (Calle, 2004: 124). En alguna ciudad como Sevilla se citan hasta 40 miembros en 1866 (Beltrán, 1997: 323). Por otra parte, si tenemos en cuenta que cada diputación arqueológica necesitaba un mínimo de 5 miembros, eso indica al menos 165 miembros en 1844. En 1864, sabemos que contaba nada menos que con 1.056 miembros repartidos por toda España, Cuba, Filipinas y extranjero (Gómez Pérez, 1958: 566).
Siendo Ministro de Fomento Claudio Moyano Samaniego, por breve tiempo, entre el 17 de enero y el 1 de marzo de 1864, quien a la vez desempeñaba el cargo de Decano de la Academia de Arqueología en 1864 (Calle, 2004: 134 n. 37), les concedió una subvención estatal (Gómez Pérez, 1958: 566), que luego fue esgrimida para la supresión de la Academia de Arqueología en 1868, por "cobrar una subvención de discutible legalidad que ha venido aumentando en los últimos años" (Calle, 2004: 143).

Los datos que disponemos de las diferentes sedes provinciales son muy fragmentarios. En Cádiz eran miembros el historiador, Gobernador Civil y luego Alcalde de Cádiz, Adolfo de Castro y Rossi; el coleccionista numismático Joaquín Rubio, que vendió parte de su colección al Real Gabinete Numismático de Dinamarca en 1847 y otra parte al Gabinete Numismático de la Biblioteca Nacional en 1858; y del epigrafista, Clemente y Francia, autor en 1846 de Inscripciones romanas de Cádiz, reunidas e ilustradas (Berlanga, 2005: 70-71). Para Almería, en 1859 estaba presidida por Ramón Orozco y su secretario era Miguel Ruiz de Villanueva (Maier $e t$ alii, 2000: 21). Esta diputación de Almería de la Academia Española de Arqueología hizo diputado de honor en 1861 a Aureliano Fernández-Guerra (Miranda, 2005: 73 fig. 48). En Sevilla era presidida en 1866 por Juan José Bueno y Leroux, su vicepresidente Francisco Mateos-Gago Fernández y el secretario, Antonio María Ariza y Montero Corvacho, siendo miembros Demetrio de los Ríos y Serrano o Francisco de Paula Collantes de Terán (Beltrán, 1997: 323, 327). La diputación de Madrid en 1864 estaba presidida por Castellanos de Losada, más Ildefonso Serafín de la Fuente como Bibliotecario, Antonio María López y Ramajo de Archivero, Luis Pérez Rico de Secretario de Gobierno, Juan de Tró y Ortolano como Secretario de secciones y diputaciones y el abogado Mariano Nougués Secall de Secretario de secciones y correspondencia extranjera (Luzón, 1993: 274).

Resulta sorprendente el alto número de delegaciones en el extranjero en las principales ciudades europeas a mediados de los años cuarenta, Roma, París, Londres, Lisboa, Atenas, Bruselas, La Haya, Copenhague, Estocolmo, San Petesburgo, más dos en América, Río de Janeiro en Brasil y Washington en los Estados Unidos (Calle, 2004: 124-125).

Sin embargo, la ausencia de publicaciones periódicas regulares para intercambio explica que de sólo 8 revistas de su biblioteca superaban los 5 ejemplares, Memoires des Antiquaries du Nord con 28, Bulletin de la Société Archéologique de Orleans con 26, Memoires de la Société 
Dunkerquaise con 17, Annales de l'Academie d'Archaeologie con 16, The Numismatic Chronicle con 10, Memoires de la Société de Archéologie de San Petersbourg con 7, Revista del Instituto de Brasil con 7 y Revue de la Numismatique Belge con 5 (Calle, 2004: 148-150), 2 francesas, 2 belgas, 1 inglesa, 1 danesa, 1 rusa y 1 brasileña, indicativo de sus modestas relaciones internacionales. Algunas de estas sociedades eligieron a Castellanos de Losada como miembro, caso de la Numismatic Society de Londres desde 1843, la Academie d'Archaeologie de Bélgica desde 1849, la Société Royale de Numismatique de Belgique de Bruselas en 1851, la Société Archéologique de Orleans en 1852, la Société Dunkerquaise de Ciencias, Letras y Artes desde 1853 o la Société des Antiquaries du Nord de Copenhague desde 1854 (Sánchez Biedma, 1868; Ruiz Cabriada, 1958: 209).

\section{LOS MUSEOS NACIONALES DE ARQUEOLOGÍA}

A mediados del siglo XIX comenzó la creación de museos para albergar de manera centralizada los hallazgos arqueológicos del propio país, dentro de los movimientos nacionalistas que culminaron con la unificación de países como Italia y Alemania en el Segundo Imperio o Reich.

En este proceso, la Sociedad de Anticuarios de Escocia creó un Museo en 1848, considerado después Museo Real, cuyo edificio fue finalizado en 1888. Más relevancia tuvo el nacimiento del Romish-Germanisches Zentralmuseum o Museo Central Romano-Germánico en Maguncia -Mainzen 1852, la capital de Renania-Palatinado. Después se produjo la transformación del Museo Archeologico Nazionale de Nápoles (1860), cambiando su antiguo nombre de Real Museo Borbónico de Nápoles (1777-1859). En Inglaterra, después de muchas peticiones, se creó en 1866 un Departamento de Antigüedades Británicas y Medievales en el British Museum, a cargo de Sir Augustus Wollaston Franks. Y en Francia, se creó el Musée des Antiquités Nationales, por Napoleón III en 1862, actual Musée d'Archéologie Nationale, en Saint-Germain-en-Laye, inaugurado en 1867, el primero europeo con la denominación de "antigüedades nacionales", que fue dirigido por Alexandre Bertrand hasta 1902.

En España, aunque este impulso incluso es anterior, no logró afianzarse por motivos presupuestarios. Ya a inicios de 1830, dos Supernumerarios de la Real Academia de la Historia, José Musso y Valiente desde 1827 y José Gómez de la Cortina desde 1829, junto con Antonio de Montenegro, solicitaron a Fernando
VII la creación de un Museo de Antigüedades. Esto motivó que por Real Orden se pidiera informe sobre "un Museo de Antiguiedades en el que se conserven los tesoros que de este género posee la España", en el que "además de recogerse y coordinarse las preciosidades que ya posee en diversos parages y adquiriese en lo sucesivo S.M. se formase una biblioteca escogida del mismo asunto, y se estableciesen enseñanzas de geografía antigua, inscripciones, numismática y demás asuntos pertinentes a Antigüedades". Cuando el tema se trató en la Real Academia de la Historia, el 5 de marzo de 1830, estuvieron presentes tanto Musso como Gómez de la Cortina, aprovechando para solicitar un edificio que también permitiese un museo que fue concedido nominalmente por Fernando VII, por Real Orden del 18 de marzo de 1833, aunque sin apoyo económico para el museo, que debería esperar a "cuando haya proporción y medios para verificarlo", al igual que las enseñanzas pues "el estado actual del R[ea]l. Tesoro no permite la dotación de cátedras para el estudio de las antiguiedades" (Almagro Gorbea y Maier, 1999: 189-190, 192; Maier, 1998: 18-19, 21 y 2003b: 39, 198-199).

El nuevo edificio fue concedido para la Real Academia de la Historia por Real Orden del 15 de julio de 1837, la actual sede en la calle León, antiguamente denominada la Casa del Nuevo Rezado, procedente de la Desamortización de Mendizábal, si bien realmente no se pudo disponer del edificio hasta 1874 (Almagro Gorbea y Maier, 1999: 195). En 1838, la Real Academia de la Historia continuó solicitando la creación de un Museo de Antigüedades, donde se depositen las antigüedades presentes en el Real Gabinete de Historia Natural, "unido o no a la Biblioteca Nacional", esto es, el Gabinete de Antiguiedades y del Museo de Medallas de la Biblioteca Nacional. Esta propuesta se concretó en una Real Orden de 21 de junio de 1838, encargándole de evaluar la creación de un Museo de Antigüedades con objetos dispersos en todo el país, emitiéndose el informe el 17 de agosto (Almagro Gorbea y Maier, 1999: 195-196; Maier, 1998: 21 y 2008: 23, 131), pero sus conclusiones no parecen haberse tenido después en cuenta.

Dos meses después de hacerse una solicitud para la creación de una Escuela de Diplomática, el 14 de enero de 1853, la Real Academia de la Historia encargó a José Amador de los Ríos y José Caveda un proyecto de creación de un Museo Central de Antigüedades, luego cambiado en el informe a Museo Nacional de Antigüedades, que se discutió el 21 de enero, nombrándose una comisión de 4 personas, indicativo de la importancia que se le otorgaba, para entregar el proyecto en el Ministerio de Gobernación. Este hecho se produjo poco antes del día 28 por la comisión formada por 
el Director, Luis López Ballesteros, Antonio Cavanilles que había participado en el proyecto de la Escuela Superior de Diplomática, y los dos autores de este proyecto, Amador de los Ríos y Caveda (Almagro Gorbea y Maier, 1999: 197; Maier, 2008: 53, 198). Por entonces, bajo la presidencia de Federico Roncali Ceruti, era Ministro de Gobernación, Antonio Benavides y Fernández de Navarrete. Sin embargo, nuevamente hubo un cambio de gobierno el 14 de abril de 1853, y entró como nuevo presidente Francisco Lersundi Hormaechea y en Gobernación, Pablo Egaña Díaz de Carpio, lo que debió paralizar el proyecto.

\section{Romanticismo y Arqueología Monumental: José Amador y Demetrio DE LOS RÍOS}

El decreto que suprimió la censura literaria el 4 de enero de 1834 y la reforma de la ley de prensa posibilitó la plenitud del romanticismo en España entre 1833-44 (Artola, 1973: 361). La corriente romántica y su revalorización del arte gótico y medieval, propició la aparición de la Arqueología Monumental, Artística o Arquitectónica, especialmente interesada en los orígenes y evolución del "arte de edificar".

Así surgió la Société Française d'Archéologie (1834), con su Bulletin Monumental y la celebración del Congrès Archéologique de France, de carácter anual desde el primero celebrado en Caén en 1834. La iniciativa principal fue de Arcisse de Caumont, autor del Cours d'antiquités monumentales (1830-41).

En Gran Bretaña, apareció la British Archaeological Association (1843), dedicada al estudio del arte, arquitectura y arqueología romana y medieval, publicando la revista The Archaeological Journal (1844) y celebrando su primer congreso en Canterbury desde 1844.

Su incidencia fue más tardía en Portugal, con la creación de la Real Associaçao dos Arquitectos Civis e Archeologos Portugueses (1863), dirigida por Joaquim Possidonio da Silva, que fue autor de dos libros importantes, Noções elementares de archeologia (1878) y Resumo elementar de archeologia christã (1887).

El arqueólogo más representativo de esta corriente en España fue José Amador de los Ríos y Serrano, Secretario de la Comisión Central de Monumentos Provinciales desde 1844, redactor del Proyecto de creación de un Museo Nacional de Antigüedades en 1853, del que llegó a ser su director en 1868 y del Reglamento de las Comisiones Provinciales de Monumentos Históricos y Artísticos en 1865.
Nació en Baena (Córdoba) el 1 de mayo de 1818 y murió en Sevilla el 17 de marzo de 1878, hermano mayor del también arqueólogo Demetrio de los Ríos, 9 años más joven. Era hijo del escultor José de los Ríos y Serrano y de María del Carmen Serrano, portabanderín de la milicia en 1820, que fue herido a bocajarro de bala en 1823 por los realistas y destruido su molino harinero en 1827 por sus ideas liberales (Valverde, 1903a: 406, 409). Residió en Baena hasta que la persecución de su padre obligó a marchar a la familia a Córdoba cuando tenía 9 años, donde ingresó en el Seminario de San Pelagio de Córdoba, mientras su padre emigró del país en 1827. Regresado en 1832, con 14 años, se trasladó la familia a Madrid, en el Colegio de los Jesuitas de San Isidro, matriculándose en pintura y dibujo en la Real Academia de Bellas Artes de San Fernando bajo la supervisión de José de Madrazo, asistiendo también en el curso 183637 a la Cátedra de Literatura que impartía Alberto Lista en el Ateneo de Madrid. Estudios que tuvo que abandonar a los 19 años al marchar la familia en 1837 a Sevilla después del motín de La Granja, matriculándose en la Escuela de Bellas Artes de Sevilla y revelándose como un notable escritor de poesías y obras teatrales, a la vez que se casó con María Juana Fernández Villalta en marzo de 1840, con la que tuvo 5 hijos, el médico Gonzalo, Isabel que casó con Francisco Fernández y González, el arquitecto Ramiro, el abogado y arqueólogo Rodrigo y el teniente Alfonso (Pavón, 1878: 108109, 120; Valverde, 1903b: 418-420, 431).

De su etapa romántica sevillana, donde priman los valores artísticos y literarios frente a una historia positivista y descriptiva, destacan Sevilla pintoresca (1844) y el breve texto, Itálica: historia de esta ciudad famosa desde su fundación hasta nuestros días, con todos sus descubrimientos (1845b), resultado de su colaboración en las excavaciones de Itálica con Ivo de la Cortina entre 1839-40. En esos días iba diariamente al yacimiento junto a Ivo de la Cortina y el cura de Santipoce, José del Toro Palma "formando los tres una pequeña sociedad (...) visitabamos juntos diariamente aquellas ruinas" (de los Ríos, 1845b en Luzón, 1999: 76). Las excavaciones se paralizaron en 1840, después del pronunciamiento de Espartero el 1 de agosto, al retirar el Jefe Político, o Gobernador Civil, los presidiarios por quitar los soldados que los vigilaba, paralizando las excavaciones, lo que desencadenó un frenético saqueo del yacimiento "y nos dedicamos don Ivo de la Cortina y yo a sacar los dibujos de todos los mosaicos que lo merecían (...) antes de que perecieran" (de los Ríos, 1845b en Luzón, 1999: 80-81). Después de casarse, se trasladó a vivir a Santiponce en 1841, con 23 años, 43, continuando las excavaciones hasta 1843. 
Se trasladó a Madrid en abril de 1844, con 26 años, al ser nombrado Secretario de la Comisión Central de Monumentos Provinciales, según Valverde (1903b: 423; Luzón, 1999: 82; Pasamar y Peiró, 2002: 526; Díaz-Andreu et alii, 2009: 562) con el apoyo del Presidente de la Comisión, el Ministro de Gobernación, Pedro José Pidal y Carniado y del Director General de Instrucción Pública, Antonio Gil de Zárate. Sin embargo, es probable que su principal apoyo haya sido el Vicepresidente de la Comisión Central, el Teniente General Serafín María de Sotto -Sutton- y Abbach Langton Casaviella, Conde de Clonard, que previamente fue Capitán General en Andalucía y conocía personalmente a Amador de los Ríos porque también asistía a la tertulia literaria en la Academia El Cisne.

En la capital continuó su trayectoria romántica más matizada en Toledo pintoresca (1845a) y la publicación durante 1846 de 13 números de la revista, Boletín Español de Arquitectura, con Antonio Zabaleta. Su reivindicación de la arquitectura mudéjar de la Península en Toledo pintoresca y el trabajo que estaba realizando en la Comisión Central de Monumentos Provinciales le permitió ser elegido, con 29 años, Supernumerario en la Real Academia de la Historia en 1847.

El Plan Pidal (1845) del Ministro de Gobernación, Pedro José Pidal y el Director de Instrucción Pública, Antonio Gil y Zarate, con su reforma en 1847, le permitió presentarse a realizar el doctorado en Filosofía y Letras y asistía a las clases de hebreo de Antonio María García Blanco, mientras trabajaba como Oficial en la Dirección General de Instrucción Pública en el desarrollo del Plan Pidal (Valverde, 1903b: 423-424). Su reforma también permitía a los autores de obras científicas reconocidas por el Consejo de Instrucción Pública presentarse a concursos de plazas universitarias.

$\mathrm{Al}$ año siguiente publicó su primera obra de madurez, Estudios históricos, políticos y literarios sobre los judios en España (1848), con 30 años, que prosigue su línea de integración de la identidad española, cristiana, árabe y judía, frente a la visión ilustrada centrada en los orígenes greco-latinos, y prácticamente enlazó con su Toledo pintoresca, pues empezó a publicar artículos en la prensa sobre el tema desde febrero de 1845 .

Este trabajo le permitió ser elegido como Numerario en la Real Academia de la Historia el 4 de febrero de 1848, el primero sin haber sido previamente Correspondiente (Siete Iglesias, 1978: 348), y pocos meses después, por decision del Consejo de Instrucción Pública, acceder a la Cátedra de Historia Crítica de la Literatura Española en la Universidad Central de Madrid desde el 7 de julio (Valverde, 1903b: 424).
En la primera mitad de los años cincuenta, su investigación se centró en la publicación de los 4 volúmenes de la Historia General y Natural de las Indias de Fernández de Oviedo (1851-55), para después centrárse en la literatura antigua y medieval, preparando los 7 volúmenes de la Historia crítica de la Literatura española (1861-65), en la que venía trabajando desde su juventud. No debe olvidarse que, desde su punto de vista (de los Ríos, 1848: xviii), la literatura castellana perdió originalidad y calidad con la expulsión de los judíos y la adopción de la corrientes renacentistas italianas que recuperaban los valores greco-latinos.

No obstante, un hallazgo ocasional, en agosto de 1858 , de 8 coronas y 5 cruces de Guarrazar (Guadamur, Toledo), quizás el más importante de esta etapa hasta 1868, junto con el disco de Teodosio, le hizo volver a sus primeros temas de investigación.

Se trató de dos hallazgos casi simultáneos, el primero resultado de una fuerte tormenta de verano que dejó al descubierto dos recintos de 0.75 x 1.60 $\mathrm{m}$. de profundidad, donde estaban ocultos. Uno fue la noche del 24 de agosto de 1858 por dos labriegos vecinos de Guadamur, Francisco Morales y su esposa, María Pérez, y otro dos días después, por el dueño de la parcela vecina, Domingo de la Cruz Figueroa, el 26 de agosto, que había visto a los anteriores deambular con luces por la noche. El matrimonio fue fragmentando el tesoro y vendiéndolo por partes a tres joyeros de Toledo, José Gómez, Mateo Gamero y Martín Vicente Velasco, y después de un regalo a un amigo, un profesor de francés en el Colegio militar de infantería de Toledo, situado en el Hospital de Santa Cruz, Adolphe Hérouart Chivot, teniente coronel de artillería en la reserva, éste contactó con el joyero, José Navarro, quien compró la parte restante en septiembre. Navarro reconstruyó las 8 coronas y joyas, donde destacaba la corona votiva del rey Recesvinto, 653-672, ofreciéndolas en enero de 1859 al Musée National du Moyen Âge o Museo Cluny de París, fundado en 1843, cuya compra se anunció en febrero de 1859 en el Bulletin de la Société Imperiale des Antiquaries de France, después de que el conservador del Museo del Louvre, Adrien de Longperier, había ordenado las letras colgantes de la corona de Recesvinto, lo que hizo pensar que venía de una necrópolis real visigoda. Para legitimar su propiedad, Hérouart había comprado la finca donde apareció el primer hallazgo el 15 de octubre de 1858 y realizó nuevas excavaciones entre el 25 de octubre y el 6 de enero, pero sólo localizó pocas joyas y unas 40 sepulturas. Figuró públicamente como el autor del hallazgo y marchó en enero de 1859 a París a gestionar la futura venta las coronas en el Museo Cluny por 72.000 reales, 
cerrada por Navarro, de los que 40.000 entregó a Morales. La reclamación del gobierno español fue rechazada por un informe de la Academia firmado por Prosper Mérimée, contrario a su devolución y amigo íntimo de Napoleón III y Eugenia de Montijo. Después del revuelo que se formó por su venta en Francia, el propietario del segundo hallazgo, Domingo de la Cruz, en el cual se encontraba la mejor pieza, la corona votiva de Suintila, 621631 , vendió algunas joyas, varias robadas por su hermana Manuela de la Cruz, pero al final prefirió llevar una muestra del hallazgo cuando la reina Isabel II estaba con la Corte en Aranjuez en mayo de 1861. Este segundo depósito, del que se conservaba 1 corona completa, 2 fragmentadas y 3 cruces fue comprado por 40.000 reales, más 4.000 reales anuales de pensión vitalicia (de los Ríos, 1861; de la Rada, 1872 y 1890; Balmaseda, 1995a: 150, 161-162, 1995b: 172-174 y 1996: 107-110). Dos láminas de revestimiento de una cruz y algunas joyas restantes fueron vendidas por el joyero José Navarro en julio de 1860 al Ministerio de Fomento en 10.000 reales (Balmaseda, 1995a: 155; Maier, 1999c: 93), pues no quiso fijar precio después de las múltiples presiones para que no cerrara la venta al Museo Cluny, falleciendo en febrero de 1862 (Balmaseda, 1999: 184). Hérouart dejó su trabajo y se marchó a vivir a París donde vendió una novena corona de retícula abalaustrada de nuevo al Museo Cluny, en marzo de 1861, al haber rechazado su compra la comisión asesora del Ministerio de Fomento, donde figuraban Delgado y FernándezGuerra, por un precio de 12-15.000 francos, la cual les ofreció en agosto de 1860, que fue tasada en 10.000 reales (Balmaseda, 1995a: 154, 1995b: 174). Aún en junio de 1864, Nicolas Jean, compró en Madrid fragmentos de cadenas de coronas, para el Museo Cluny (Balmaseda, 1995a: 154). Del conjunto vendido por Domingo de la Cruz, la corona votiva de Suintila fue robada de la Armería Real en 1921 (Lázaro Galdeano, 1925) y un florón con colgante de otra corona y un gran fragmento de una corona de retícula fue robada en octubre de 1936, al inicio de la Guerra Civil del Palacio Real (Balmaseda, 1995a: 150, 160).

El joyero José Navarro había sido el autor de la restauración del Missorium de Teodosio como indica Delgado (1848: 12). Por otra parte, como también pasó después con el hallazgo y venta de la Dama de Elche por el retraso en los pagos de la colección Ibarra, la opción de una venta en el extranjero fue debida en parte a que la reina Isabel II había encargado una nueva corona al joyero José Navarro en 1850, pero había tardado 5 años y medio en pagarla.

Como indica en una carta de marzo de 1859 al Ministro de Estado, "El año 1850 me retiré (...) vinieron a buscarme en mi retiro para que me encargara de la construcción de la corona real, objeto que no se había hecho en España desde hacía cuatro siglos (...) para lo cual tuve que distraer los fondos que destinaba a la casa. Concluí y entregué la corona la víspera del atentado del cura Merino [2-2-1852] (...) Han tardado en pagarme cinco años y medio (...) Durante los cinco años y medio he tenido que vivir poniendo en el monte de piedad cuanto tenía (...) pasé mil disgustos porque a nadie le constaba que me debían esa corona en palacio, ni siquiera me dieron un recibo para con él obtener el crédito que había perdido" (Balmaseda, 1999: 179).

Teniendo en cuenta el buen conocimiento de Amador de los Ríos sobre Toledo, bien reflejado en Toledo pintoresca (1845a) y su etapa como director de las excavaciones de Itálica entre 1841-43, debió pensarse en la Real Academia de la Historia que era la persona adecuada para hacer las investigaciones de campo, que por su importancia no se delegaron en la Comisión Provincial de Monumentos de Toledo.

Las excavaciones se realizaron entre el 10-17 y 25-28 de abril de 1859, dirigidas por Amador de los Ríos y Emilio Lafuente Alcántara, oficial del Ministerio de Fomento, con la ayuda de 8 presos. Se hizo un trazado de zanjas, levantándose capas de 4-6 pulgadas de espesor y se cribó la tierra extraída y la procedente de las rebuscas de Hérouart, mientras que Jerónimo de la Gándara, profesor de la Escuela de Arquitectura, hizo un levantamiento topográfico. Se descubrió parte de una iglesia y en su interior sepulturas, una con inscripción del año 693, mientras que la necrópolis descubierta por Hérouart y Morales se extendía al oeste de la iglesia. Estos resultados permitieron a Amador de los Ríos (1861; Balmaseda, 1997: 209212) proponer que las coronas votivas y las cruces procedían de esta iglesia.

Ya en su Toledo pintoresca había definido una sucesión de corrientes artísticas en la arquitectura, árabe-bizantina, árabe-mauritana, árabe-andaluza y mozárabe o morisca (de los Ríos, 1845: 228). Estos nuevos estudios le hicieron retomar su interés por la arquitectura visigoda y mudéjar, que fueron desarrollados en El estilo mudéjar en la arquitectura (1859: 7-8), su discurso de ingreso en la Real Academia de Bellas Artes de San Fernando, centrado en el arte que antes había denominado mozárabe, resultado "de la política tolerante que da vida a los vasallos mudéjares de la corona de Castilla", y en la memoria sobre las excavaciones de Guarrazar, El arte latino-bizantino en España y las coronas visigodas de Guarrazar (1861), donde defiende que el arte visigodo es de origen tanto cristiano latino desde el Tercer Concilio de Toledo, 
589 d.C., como bizantino a partir del reinado de Justiniano, 527-565 d.C., pues los visigodos abandonaron su estilo propio, y de este arte visigodo de tradición latino-bizantina surgió el arte asturiano, frente a las tesis de Ferdinand de Lasteyrie en Description du Trésor de Guarrazar (1860), que lo consideraba arte germánico por la presencia de la técnica de vidrio rojo incrustado en cloisonné.

Ya por entonces, sus ocupaciones eran múltiples. Elegido Diputado por Almería en 1863, tuvo que incorporar primero a Juan de Dios de la Rada y Delgado para la redacción de la Historia de la Villa y Corte de Madrid (de los Rios, de la Rada y Rosell, 1860-64), que se convirtió en su mano derecha y después a Cayetano Rosell. Fue elegido además Vicerrector de la Universidad Central de Madrid el 29 de octubre de 1867 y Rector desde el 8 de mayo de 1868, además de Director del Museo Arqueológico Nacional el 5 de febrero de 1868 (Valverde, 1903b: 429).

Nombrado desde el 19 de junio de 1874, Inspector General de Instrucción Pública, a partir de 1876 su vida se vio marcada por la muerte de dos hijos. Primero el más pequeño, el Teniente de Infantería Alfonso de los Ríos, que murió el 30 de enero de 1876 de una granada en la batalla de Oteiza contra los carlistas y después su hijo mayor, el médico Gonzálo de los Ríos, el cual falleció en junio cuidando a los soldados enfermos del cólera en Cuba (Valverde, 1903b: 429, 431).

En sus últimos años, estos trabajos sobre el arte latino-bizantino los amplió a la ciudad de Mérida (de los Ríos, 1877a) y Córdoba (de los Ríos y Amador de los Ríos y Fernández-Villalta, 1879), trabajo ya aparecido póstumamente, con la colaboración de su hijo Rodrigo Amador de los Ríos. Deprimido, optó por marchar de Madrid, primero a Córdoba, luego a Málaga y finalmente a Sevilla, donde falleció el 17 de febrero de 1878 (Valverde, 1903b: 431-432).

La colección de Monumentos arquitectónicos de España fue una importante iniciativa de la Escuela Superior de Arquitectura para valorizar el patrimonio monumental español, del que se publicaron 11 volúmenes entre 1859 y 1881, que abarcaron las provincias de Alicante, Ávila, Badajoz, Barcelona, Burgos, Cáceres, Córdoba, Gerona, Granada, Guadalajara, León, Madrid, Mérida, Oviedo (Cámara Santa), Salamanca, Segovia, Toledo, Valencia, Valladolid y Zamora. La coordinación de la misma estuvo a cargo de Manuel de Assas, como secretario de la comisión encargada de su publicación desde el 3 de junio de 1856, a la que también pertenecía Amador de los Ríos.

Su hermano, Demetrio de los Ríos y Serrano, nació en Baena (Córdoba) el 26 de junio de 1827, sufriendo también los cambios de la residencia de su padre, viviendo en Córdoba hasta 1832, con 5 años, en Madrid hasta 1837, con 10 años y a partir de entonces en Sevilla.

Se tituló como arquitecto el 20 de abril de 1852 , con 25 años, que le permitió acceder por oposición en junio de 1852 al puesto de Arquitecto Municipal de Sevilla y después a la Cátedra de Topografía en la Escuela de Bellas Artes de Sevilla (Valverde, 1903c: 439).

Retomó como miembro de la Academia Española de Arqueología desde 1853, las excavaciones de Itálica a partir del 24 de enero de 1860 hasta 1868 (Luzón, 1999: 86, 90), publicando un avance, la Memoria Arqueológico-Descriptiva del Anfiteatro de Itálica (1862), mientras que quedó inédita la monografía con sus actuaciones y la de su hermano José Amador de los Ríos, Itálica. Historia y descripción artística de esta infortunada ciudad (1879) (Gali, 1892; Canto de Gregorio, 2001: 154 n. 5; Rodríguez Hidalgo, 2007: 566-567 n. 51).

Fue nombrado Vicepresidente de la Comisión Provincial de Monumentos de Sevilla desde 1862 y Director del Museo Arqueológico de Sevilla desde 1866, situado en el Convento de la Merced, que ocupó hasta 1879, cuando dejó el puesto al marchar a León, siendo transferido al Cuerpo Facultativo de Archiveros y Bibliotecarios, nombrándose a Manuel de Campos.

Después de la Revolución de 1868, Demetrio de los Ríos realizó nuevas campañas de excavación entre julio de 1872 hasta 1874, financiadas por la dueña de los terrenos, Candelaria Rodríguez, en el Olivar de Las Coladas, donde documentó varios mosaicos como los de Hylas, Neptuno, Patio Rodio y los Pájaros (Gali, 1892; Luzón, 1999: 96-97). Desde 1880 se centró en la restauración de la Catedral de León, al morir el arquitecto precedente, Juan de Madrazo, falleciendo en esta ciudad en 1892.

\section{EDUARDO SAAVEDRA Y LAS EXCAVACIONES DE NumanCIA}

La investigación arqueológica de campo más destacable, por su continuidad y apoyo institucional en este periodo, fue la excavación de Numancia, a través de la Real Academia de la Historia, dirigida por Saavedra. Su principal defecto fue que no se publicó una memoria científica con sus resultados, sino años después un breve resumen (Olózaga, Delgado y Fernández-Guerra, 1877: 55-59).

Eduardo Saavedra y Moragas nació en Tarragona el 27 de febrero de 1829 y murió en Madrid el 12 de marzo de 1912. Era hijo del militar coruñés, Ignacio Saavedra Dumont, que le aportaba también familia francesa y de la tarraconense 
Francisca Moragas Jenkins, con familia inglesa. A la vez que estudiaba Derecho se diplomó primero en lengua árabe en noviembre de 1847, a los 18 años. Se había formado con Gayangos como recordaba, "Cuando cursaba primer año de Derecho romano en la Universidad de Madrid, acerté a pasar por delante de un aula, donde de pie y junto a un encerado, trazaba signos desconocidos un profesor de simpática figura. Hizome entrar la curiosidad, me aficionó la explicación y al segundo día de asistencia el catedrático me tomó bajo su protección, me llevó a su casa y, sin averiguar quién era yo (...) me proporcionó gramáticas y crestomatías que no me era dable adquirir; me dejó llevar manuscritos árabes" (Saavedra, 1897: 227). Después comenzó a estudiar ingeniería de caminos en la Escuela Superior de Ingenieros de Caminos, Canales y Puertos desde 1846, licenciándose en septiembre de 1851 con 22 años, como el primero de su promoción. No dejó de estudiar y obtuvo el título de arquitecto en 1870, con 41 años, lo que le permitió dirigir la rehabilitación de la Casa del Nuevo Rezado como sede de la Real Academia de la Historia (Sáenz García, 1964: 9-10; Mañas, 2007: 86-88).

Justo al acabar fue destinado como ingeniero a Soria entre noviembre de 1851 hasta diciembre de 1853 (Sáenz García, 1964: 9, 17), donde estudió el trazado de la vía romana desde Asturica (Astorga) a Caesaraugusta (Zaragoza), centrándose en el tramo de Uxama (Osma) a Agustóbriga (Muro de Ágreda), de $153 \mathrm{~km}$., en cuyo tramo central estaba Numancia, trayecto hoy seguido por la Autovía del Duero, redactando Descripción de la Vía romana de Uxama a Augustóbriga (Saavedra, 1861/1879).

Ya en este trabajo había tratado de confirmar el emplazamiento de Numancia, iniciando excavaciones en 1853 , unos $5.000 \mathrm{~m}^{2}$. Para su continuación, fundó la Sociedad Arqueológica Numismática en 1854, que la Real Academia de la Historia trató de colocarlas bajo su inspección después de ser informada por Saavedra, solicitándose subvención al Ministerio de Gracia y Justicia de 10.000 reales que fue concedida, en el Bienio Progresista, a finales de abril o inicios de mayo de 1854, e ingresado en enero de 1855 (Álvarez Sanchís et alii, 2000: 288-291). Sin embargo, las excavaciones no se iniciaron, ni se utilizó el dinero, hasta la realización de una serie sucesiva de campañas a partir de agosto de 1861, cuando se gastó la primera subvención (Álvarez Sanchís et alii, 2000: 293). El presupuesto se incrementó entre los años 1862-65, al concederse anualmente 25.000 reales, de los 50.000 presupuestados para excavaciones de la Real Academia de la Historia (Álvarez Sanchís et alii, 2000: 294-297), durante la Unión Liberal, con el objetivo último de celebrar en 1867 los 2.000 años de la "Epopeya Numantina" el 133 a.C. Las excavaciones, de acuerdo con el plano general de las campañas de 1860-63, cubrieron una superficie de $15.000 \mathrm{~m}^{2}$, con 3 trincheras de E-W y una trinchera de N-S, abarcando 9 manzanas de la ciudad, aunque la memoria final permanece inédita (Olózaga, Delgado y Fernández-Guerra, 1877; Jimeno y de la Torre, 2005: 140-141).

Este yacimiento ya refleja el inicio de la búsqueda de un pasado nacional a través de la arqueología, que confirmaría las referencias al heroísmo de los celtíberos en las fuentes clásicas, como ya estaba pasando con los etruscos italianos, los celtas galos o los germanos alemanes. Fue declarado Monumento Nacional por Real Orden de 25 de agosto de 1882 .

A partir del 15 de diciembre de 1853 se incorporó como profesor en la Escuela Superior de Ingenieros de Caminos donde permaneció hasta 1862. Al año siguiente se incorporó a la Compañía del Ferrocarril de Palencia a Ponferrada, elaborando los tramos Palencia-León y León-Astorga (Sáenz García, 1964: 17; Mañas, 2007: 87). Durante esta etapa Saavedra realizó excavaciones en Lancia, hacia 1863, localizando estructuras y sepulturas romanas (González Alonso, 1997: 200). Se reincorporó como profesor a la Escuela de Caminos el 24 de julio de 1866, a la vez que se matriculó en la Escuela Superior de Arquitectura, donde después de una convalidación inició en tercer curso y finalizó el 20 de mayo de 1870 (Sáenz García, 1964: 34-35). En esta estapa relacionó el estudio de las vías romanas con la arqueología monumental, como refleja su discurso de ingreso en la Real Academia de la Historia, Obras públicas y monumentos en la España antigua (1862).

A partir de la Revolución de 1868, y entrar como Ministro de Fomento, el soriano Manuel Ruiz Zorrilla, del Partido Progresista, quien conocía su labor en la provincia, fue nombrado Jefe de Negociado de Ferrocarriles y después desde el 19 de julio de 1869, Director General de Obras Públicas, Agricultura, Industria y Comercio, hasta el 19 de enero de 1871. Vuelto a incorporar a la Escuela Superior de Ingenieros de Caminos dejó el puesto el 14 de octubre de 1871 en un momento de recorte de plantillas, hasta que se incorporó como vocal el 21 de septiembre de 1873 a la Junta Superior Consultiva de la Armada del Ministerio de la Marina y finalmente Presidente en la Junta Consultiva de Caminos, Canales y Puertos del Ministerio de Fomento (Sáenz García, 1964: 3536; Mañas, 2007: 87).

En esta etapa final sus publicaciones más relevantes fueron en el arabismo como La geografía de España del Edrisi, que fue publicando en el Boletín 
de la Sociedad Geográfica de Madrid entre 1881 y 1883 y el Estudio sobre la invasión de los árabes en España (1892).

Otro de sus principales intereses fue la potenciación de la Sociedad Geográfica de Madrid, de la que fue uno de los fundadores el 2 de febrero de 1876, su segundo Presidente desde septiembre y luego Presidente honorario, después de la Exposición de París de 1875, que se aprovechó para celebrar un congreso geográfico internacional, y ante la ausencia de representación española se trató de paliar cuanto antes (Foronda, 1912: 411-414).

Desempeñó entonces altos cargos como Senador, representando a la Real Academia de la Historia entre febrero de 1895 hasta su fallecimiento en marzo de 1912, Director interino de la Real Academia de la Historia desde el 26 de junio de 1908, y Director en propiedad desde el 11 de diciembre de 1908, frente a la candidatura conservadora de Menéndez y Pelayo, después de tres votaciones (Siete Iglesias, 1978: 563), pero renunció un año después, permitiendo la elección de Marcelino Menéndez y Pelayo, el 17 de diciembre de 1909.

En sus últimos años, según señalaba en un discurso necrológico Fernández de Béthencourt (1912: 538), estaba "enteramente ciego y casi sordo", por lo que se valía siempre "de lectores y taquígrafos que le auxiliaban en su tarea". En esas condiciones ayudó a Schulten para que pudiese obtener el permiso de excavación en Numancia, quien sin aparentar reconocerlo, lo describió como "un señor ya mayor nos dirigió algunas palabras amables pero incomprensibles, luego me enteré de que había intentado hablar en Alemán" (Schulten, 1953: 20-21).

\section{Antonio Delgado, Renovador De LA NUMISMÁTICA EN ESPAÑA}

En la obra numismática del Anticuario Antonio Delgado encontramos una de las grandes aportaciones de la arqueología española del siglo XIX. Antonio Delgado y Hernández nació en Sevilla el 9 de enero de 1805, hijo del futuro Alcalde constitucional de Sevilla entre 1820-23, el abogado Francisco Javier Delgado y Jurado, nacido en Bollullos del Condado (Huelva) y de María Josefa Hernández y Aguirre. Marchó al Colegio de Santo Tomé de Sevilla en 1814, empezando después Derecho en la Universidad de Sevilla, pero sin acabar los estudios se alistó en la Milicia Nacional de Sevilla en 1823, luchando en el Trocadero de Cádiz y sufriendo después unos días de prisión por Fernando VII.

Tuvo que retirarse a vivir con su padre a Trigueros (Huelva), donde permaneció hasta el regreso de los liberales en 1833, al iniciarse la Regencia de María Cristina de Borbón. Estos le nombraron Oficial Mayor y Jefe de Sección de la Diputación de Huelva desde el 10 de diciembre de 1835 y después Secretario de la Diputación entre el 4 de marzo de 1836 y el 27 de octubre de 1840.

Su padre era aficionado a la numismática, afición que heredó, colaborando ambos en el estudio del puteal romano de Trigueros en 1828. Ya trabajando en la Diputación fue Secretario y VicePresidente de la Comisión de Monumentos Histórico Artísticos de la Provincia de Huelva, de la que fue cesado entre 1840-43, durante la Regencia de Espartero, hasta que fue repuesto en el cargo el 17 de febrero de 1844.

El 24 de diciembre de 1845 fue nombrado Auxiliar del Consejo Real en Madrid, ingresando el 20 de noviembre de 1846 como Supernumerario en la Real Academia de la Historia y Socio de la Sociedad Económica Matritense. Dos años después, el Anticuario de la Real Academia de la Historia renunció a su puesto por residir en Toledo, lo que facilitó su nombramiento como Numerario el 5 de marzo de 1847 y Anticuario desde el 14 de julio de 1848. En su trabajo ascendió a Mayor de la sección de Gobernación y Fomento en el Consejo Real, el 7 de noviembre de 1851 hasta el 7 de noviembre de 1854, y Secretario interino del Consejo de Estado desde el 9 de noviembre de 1856 (Fabié, 1877: 410-413, 416; Belmonte, 1880/2001: xxvii-xxxviii).

Cesado durante 2 años, durante el Bienio Progresista al regresar Baldomero Fernández Espartero como Presidente de Gobierno, pasó del Partido Moderado de Narváez a la Unión Liberal de O'Donnell, siendo elegido Diputado a Cortes por Aracena (Huelva) el 9 de mayo de 1857 y de nuevo el 13 de diciembre de 1858. Ese año fue encargado de la dirección en funciones de la Escuela Superior de Diplomática desde el 29 de agosto de 1858 (Fabié, 1877: 416-417; Belmonte, 1880/2001: xxxviii), que dirigió hasta 1865 . Era una persona agradable, "de carácter afable y por todo extremo bondadoso de aquel hombre, a quien creo que nadie vio jamás enojado" (Fabié, 1877: 413).

Como Anticuario su trabajo más representativo fue el estudio del disco de Teodosio localizado en Badajoz en 1847, una bandeja ceremonial de plata con dos copas, Memoria histórico-crítica sobre el gran disco de Teodosio, encontrado en Almendralejo (1849).

Sus principales viajes de campo fueron entre febrero y abril de 1853, como comisionado del Gobierno para estudiar el supuesto enterramiento egipcio aparecido en Tarragona y en abril de 1859 
a Murviedro, actual Sagunto (Valencia), para estudiar las fortificaciones, teatro e inscripciones (Belmonte, 1880/2001: xxix; Maier, 2008: 62, 198200, 232).

Durante su cargo de Anticuario, comenzó a publicar trabajos de numismática a partir de 1852 , incluso en la Revue Numismatique desde 1853, y elaboró tres catálogos, uno de moneda hispanorromana, fenicia, bilingües y desconocidas, otro de moneda romana-republicana y un tercero de moneda árabe. Los manuscritos fueron denominados Monedas de Reyes, Pueblos y Ciudades antiguas clasificadas por provincias romanas de Lusitania, Bética y Tarraconense, Catálogo descriptivo de la serie de monedas de plata y cobre acuñadas durante la República de Roma y finalmente Monedas Arábigo-Hispanas. Los tres catálogos son fechados por Martín Escudero, Cepas y Canto García (2004: 50) en 1862 y formarían parte del Catálogo descriptivo del Museo Numismático de la Real Academia de la Historia de Madrid.

No obstante, ya en reunión del 14 de enero de 1853 (Maier, 2008: 198), Delgado presentó un índice y clasificación del monetario de la Real Academia de la Historia. Por otra parte, Delgado llevaba desde 1848 como Anticuario y es probable que hubiesen sido redactados en buena parte en los 14 años que desempeñó el cargo. Por ejemplo, las monedas de las series autónomas del monetario y de los reyes visigodos ya las tenía clasificadas en junio de 1847 (Maier, 2008: 176), lo que implica que ya inició la clasificación del monetario antes de ser nombrado Anticuario, probablemente empezó al ser Supernumerario desde noviembre de 1846, y sobre su libro sobre Estudios de Numismática Arábigo-Hispana ya comenta, en sesión del marzo de 1851, que lo tiene "casi concluido" (Maier, 2008: 190). Había aprendido a leer los epígrafes de las monedas arábigas con Gayangos (Fabié, 1877: 414). Es interesante observar que Delgado se llevó el original del catálogo del Gabinete de Antigüedades a Huelva (Maier, 2008: 356) y en 1874 le fue reclamada una copia por el Anticuario de la Academia, 5 años antes de su fallecimiento, el 13 de noviembre de 1879, en Bollullos del Condado (Huelva), donde desde enero de 1875 había sido nombrado Alcalde del pueblo (Fabié, 1877: 422; Belmonte, 1880/2001: xl).

Un escrito situado entre 1864-66 menciona que el Gobierno "tiene encomendadas a Sr. Don Antonio Delgado (...) la publicación de dos obras importantes sobre numismática española, relativas una a monedas autónomas de épocas remotas, y otra a las acuñadas durante la dominación arábiga en la península" (Martín Escudero, Cepas y Canto García, 2004: 53 fig. 25), pero por su amigo
Fernando Belmonte (1880/2001: xl) sabemos que al menos la segunda obra sobre moneda arábiga le fue encargada por el Gobierno desde 1859 y de la primera sobre monedas ibéricas y de caracteres desconocidos, también por encargo del Gobierno, "empezó a cumplir depositando sucesivamente en la Dirección General de Instrucción Pública el fruto de sus tareas; pero circunstancias que desconocemos impidieron por entonces la publicación" (Belmonte, 1880/2001: 1x).

Este manuscrito del Nuevo método de clasificación de las medallas autónomas de España (187173), finalmente fue publicado en 3 volúmenes por el Círculo Numismático de Sevilla. No debía estar acabado, y fue completado por Mateos-Gago, importante miembro de Academia Española de Arqueología en Sevilla y otros miembros del Círculo Numismático. Como señala en una carta Zobel de Zangróniz, "discípulo predilecto del Sr. Delgado" (Fabié, 1877: 421), "dicho señor, a su edad y con sus pacíficas tareas agrícolas, no se ocupa hace tiempo de numismática. De ahí que muchos artículos de la obra que lleva su nombre tengan que ir con otras firmas, y muchos trozos, aun sin firma alguna, no sean tampoco de Delgado (...) Me sospecho que en lo que dicha obra se dice con respecto a VCIA, no salió nunca de su pluma, sino de la del Padre Mateos Gago" (Mateu y Llopis, 1949: 152).

Respecto a sus Estudios de Numismática Arábigo-Hispana como comprobante de la dominación islámica en la Península (1864), aunque se pidió presupuesto en 1864, comenzaron a imprimirse las 18 primeras láminas y el primer pliego entre 1865, y después de ser autorizado por el Ministerio de Fomento la impresión de 1500 ejemplares en marzo de 1866, no se continuó su edición completa (Delgado, 1864/2001: xxiii; Maier, 2008: 275).

Una posible explicación podría ser el cambio de gobierno el 10 de julio de 1866, entrando Ramón María Narváez, como Presidente del Gobierno hasta abril de 1868, sustituyendo a O'Donnell y como Ministro de Fomento de Manuel de Orovio Echagüe. Antonio Delgado, antiguo miembro del Partido Moderado de Narváez, había participado como Diputado de la Unión Liberal en la votación contra Narvaez el 30 de abril de 1858 (Belmonte, 1880/2001: xxxviii), que provocó el cese del Presidente del Gobierno, Francisco Javier Isturiz, lo que permitió la entrada de O'Donnell por 5 años entre el 30 de junio de 1858 y el 17 de enero de 1863 y favoreció su nombramiento como Director en funciones de la Escuela Superior de Diplomática en 1858, y es posible que la paralización de la publicación del libro fuera una represalia. 


\section{Arabistas y hebraístas en LAS CORRIEN- TES ORIENTalistas: Pascual de Gayangos y Antonio García Blanco}

El interés romántico por el arabismo en España tiene quizás su mejor punto de arranque en el libro de James Cavanagh Murphy, The Arabian Antiquities of Spain (1818) y en la literatura en los Cuentos de la Alhambra (1832) de Washington Irving. El interés de arquitectos e historiadores del arte propició que se hicieran levantamientos de algunos edificios paradigmáticos, como sucedió con la Alhambra de Granada por los arquitectos Jules Goury y Owen Jones en 1834 y 1837 (Jones y Goury, 1842).

Entre los arabistas más representativos destaca Pascual de Gayangos y Arce. Nació en Sevilla el 21 de junio de 1809 y falleció en Londres el 5 de octubre de 1897, hijo de José de Gayangos y Nebot, brigadier de artillería, y Francisca Arce de Retz, con antepasados franceses por parte de madre. Al regresar su padre de México, donde había sido gobernador militar de la provincia de Zacatecas, con la familia en 1820, estudió un curso en las Escuelas Pías de Madrid entre 1820-21 y otro en los Reales Estudios de San Isidro en 182122, hasta que le enviaron a Francia en 1822, cuando tenía 13 años, a la Escuela Real Militar de Pontle-Voy (Loira) hasta 1825. Muerto su padre, su madre optó por residir en París debido a las persecuciones ocurridas después del Trienio Liberal. Pasó a trabajar para el Ministerio de Estado francés entre 1825-28, asistiendo durante 3 años a las clases de árabe con el orientalista Silvestre de Sacy en la École spéciale des Langues Orientales, autor de una importante gramática árabe (de Sacy, 1831). En mayo de 1828, con 18 años, se casó en Londres con la británica, Francis -Fanny- Rebell, hija del político liberal radical británico John Rebell, que había conocido un año antes en París (Roca, 1897: 545-546, 548-549; Vallvé, 1997: 467). Tenía una formación excelente para la época, escribiendo y hablando, en árabe, francés, inglés e italiano, conocedor de latín y griego, leía el alemán, y cumplidos los 80 años, pues murió a los 88 , aprendió persa (Roca, 1898: 111-112).

Regresó a España después de su boda y empezó trabajando para la Real Hacienda en julio de 1830, primero en Málaga y después en Madrid, donde desde abril de 1833 fue intérprete de lenguas, principalmente del árabe, en el Ministerio de Estado. Ese año comenzó la catalogación de los manuscritos árabes de la Biblioteca Nacional, donde coincidió con Castellanos de Losada, que ese año fue nombrado escribiente y en 1834 pasó al Gabinete de Medallas. Por entonces, la única Cátedra de Árabe que existía en España, en los Reales Estudios de Colegio Imperial en San Isidro, era detentada por el jesuita padre Juan Artigues y Magdalena Ferragut, desde 1824 hasta 1834, donde también era el bibliotecario, el cual resultó muerto en la matanza de frailes del 17 de julio de 1834, sustituido por el padre R. Gasset en el curso 1834-35, definido por Gayangos como "un ignorante jesuita incapaz de formar un discípulo" (Roca, 1897: 550, 554-555, 557).

Ante la prevista convocatoria de una Cátedra de Árabe, trasladada del Colegio de San Isidro a la Universidad de Madrid desde octubre de 1835, pidió permiso de 4 meses para preparársela, con el visto bueno del Presidente del Gobierno y Ministro de Estado, Francisco Martínez de la Rosa Berdejo, y marchó a Londres y París. La plaza no se convocó y estuvo como Catedrático de Árabe del Ateneo de Madrid en el curso 1836-37, con una treintena de alumnos. Con 28 años, y su mujer embarazada, renunció a su trabajo y optó por marcharse a Londres en agosto de 1837 (Roca, 1897: 559, 561-562).

Al final se quedó durante 6 años en Londres, ante la falta de puestos de trabajo en España, etapa que aprovechó para redactar su trabajo más conocido, la traducción de al-Maqqari, The History of the Mohammedan Dynasties in Spain (1840-43) para la Asiatic Society de Londres, lo que permitió su nombramiento como Socio de Número, que sólo tenía hasta entonces un extranjero, su maestro el Barón de Sacy y como Correspondiente de la Real Academia de la Historia el 22 de enero de 1841, aunque el texto de al-Maqqari no lo tradujo completo. Durante estos años subsistió con encargos editoriales, artículos y la compra venta de libros para coleccionistas entre Madrid y Londres, con el apoyo desde Madrid del catedrático de árabe en el Ateneo de Madrid durante el curso 1837-38, el malagueño Serafín Estébanez Calderón, que después fue nombrado Jefe Político o Gobernador Civil de Sevilla (Roca, 1898: 14-15, 75; Álvarez Millán, 2004: 47-48; Rivière, 2000: 45 n. 37), tío segundo de Antonio Cánovas del Castillo.

Cuando se creó la plaza de catedrático de Árabe de la Universidad de Madrid se presentó y la ganó permaneciendo en ella desde 1843 hasta 1871, e ingresó en la Real Academia de la Historia como Supernumerario en 1850. Elaboró un manual con los Principios elementales de la escritura arábiga y modelo de escritura (1861).

Ya jubilado, fue Director General de Instrucción Pública con los liberales en 1881-83 y dos veces Senador por la Real Academia de la Historia en 1884 y 1886, pasando después a residir habitualmente en Londres.

De los arabistas discípulos de Gayangos, el más importante fue José Moreno Nieto y Villarejo. Nació en Siruela (Badajoz) en 1824, muriendo en Madrid el 24 de febrero de 1882. Estudió en el 
Monasterio de Guadalupe donde aprendió latín, griego y hebreo. Después se matriculó en la Universidad de Toledo entre 1835-43, haciendo los 3 años de Bachiller de Filosofía y Letras y 4 años en Leyes, licenciándose en Derecho por la Universidad de Madrid después de cursar su último año en 1844-45. En Toledo había comenzado desde el curso 1841-42 a estudiar árabe, continuando un año más con Gayangos en Madrid y finalmente consiguió el título en mayo de 1846 (Torres, 1882: 478-479). Catedrático de Árabe de la Universidad de Granada entre 1847-58, fue durante este periodo elegido Diputado a Cortes, representando a Granada en 1854, por el Partido Progresista de Mendizábal. Mientras impartía clases completó la carrera de Derecho y obtuvo el grado de Doctor en Derecho Administrativo en junio de 1860. Ya estaba pensando en quedarse en la capital y opositó a la Cátedra de Historia de los Tratados en la Universidad de Madrid que obtuvo el 14 de enero de 1861 (Torres, 1882: 480). Se incorporó en 1860 a la Unión Liberal de O'Donnell, siendo elegido Diputado a Cortes por Badajoz en 1865 y después de la Revolución del 68, fue elegido Diputado por Castuera (Badajoz) en 1869, 1871 y 1872. Rector de la Universidad de Madrid en 1872, durante el reinado de Amadeo I y la Primera República, a su caída, en 1874, fue nombrado Director General de Instrucción Pública, durante la presidencia del general Serrano. Con la restauración se incorporó al Partido Conservador de Cánovas del Castillo y fue en dos ocasiones diputado por Badajoz en 1876 y 1879. Numerario de la Real Academia de la Historia el 7 de noviembre de 1862, con el apoyo de Sabau, Gayangos, Fernández-Guerra, Rosell y el Conde de Canga Argüelles (Siete Fuentes, 1978: 568). En 1874 fue elegido presidente de la Real Academia de Jurisprudencia y Legislación y Senador por la Real Academia de la Historia en 1881. Su principal obra científica fue la Gramática de la lengua arábiga (1872), encargo del Gobierno, que entregó en 1863 , pero que no se publicó hasta casi 10 años después (Torres, 1882: 479).

Otro de sus discípulos fue Francisco Fernández y González, ahijado de Amador de los Ríos al casarse con su hija, Isabel Matilde. Nacido el 23 de septiembre de 1833 en Albacete, hijo de padre militar. Estudió en Madrid, en los escolapios y luego en el Colegio de San Isidro, siendo becado para la Escuela Normal de Filosofía entre 1850-52, acabando los estudios los dos años restantes en la Facultad de Filosofía y Letras en 1854 y los del doctorado en el curso 1854-55. Una vez obtenido el Grado se presentó a la Cátedra de Literatura General y Española en la Universidad de Granada ganándola el 11 de febrero de 1856 y tomo posesión el 24 de octubre, la cual detentó hasta 1864. Durante estos años cursó la carrera de Derecho que le permitió ejercer también de abogado. También asumió como acumulada la docencia de árabe en la universidad. Pasó a Catedrático de Estética en la Universidad de Madrid en 1864, que durante dos años impartió su suegro, Amador de los Rios entre 1862-64, cátedra de doctorado creada a solicitud de Julián Sánz del Río que había sido miembro del tribunal de la cátedra que ganó en Granada y director de su tesis doctoral, La idea de lo bello y sus conceptos fundamentales (1858), y además entre las obras de Krause (1837) estaba su Compendio de Estética, que tradujo al castellano Francisco Giner de los Ríos. En Madrid, Fernández y González llegó a Senador entre 1878-1885 y 1891-1892, Rector (1895-1903) y Numerario de las Reales Academias de la Historia (1866), con el apoyo de Gayangos, Sabau, Quadrado y Caveda (Siete Fuentes, 1979: 10), Bellas Artes de San Fernando (1881) y Española (1889), falleciendo en Madrid el 30 de junio de 1917.

Participó en la reivindicación de los mozárabes o mudéjares, al igual que José Amador de los Ríos, destacando su libro, Estado social y político de los mudéjares de Castilla, considerados en sí mismos y respecto de la civilización española (1866), premiada en 1865 por la Real Academia de la Historia, que culminaba uno de los trabajos que había deseado redactar Gayangos, la historia de los moriscos españoles.

Durante su etapa granadina, se creó la Sociedad Histórica y Filológica de Amigos del Oriente (1860), por impulso de Francisco Fernández y González, Juan Facundo Riaño y Montero y Leopoldo Eguilaz y Yanguas, que publicó las Historias de Al-Andalus por Aben-Abharí de Marruecos (Fernández y González, 1860).

Un autor que puede incluirse en esta corriente orientalista es la fase inicial de Manuel de Assas y de Ereño. Nacido en Santander el 28 de junio de 1813, ciudad donde también falleció el 16 de junio de 1880, era hijo de Pedro de Assas del Castillo, capitán de la armada y comandante del puerto de Santander y de Magdalena Ereño Santa Coloma. Realizó el Bachiller de tres años en Filosofía en el Seminario de Burgos entre 1825-27, comenzando a estudiar Derecho en la Universidad de Valladolid entre 1828-34, marchando luego a Madrid en 1835, donde se licenció como abogado el 3 de junio de 1836. Entre 1837-39 fue alumno de la Cátedra de Delineación de Arquitectura que impartía en el Instituto Cántabro el arquitecto municipal de Santander, Antonio de Zabaleta, quien desde 1845 fue el director de la Escuela Superior de Arquitectura de Madrid (Ruiz Cabriada, 1958: 122; Renedo, 2004: 95), publicando assas en 1839 un Diccionario General de Arquitectura.

Fue destinado a Burgos para inventariar los bienes desamortizados en junio de 1842 (Ruiz 
Cabriada, 1958: 122), que estaban siendo depositados en el Seminario Conciliar de San Jerónimo.

Sabemos de su presencia en Madrid a partir de 1846, cuando comenzó a impartir regularmente clases en el Ateneo de Madrid con 33 años, inicialmente sobre Arquitectura y Arqueología Monumental, Historia de la Arquitectura Española (1846-47), Historia de las Bellas Artes (1848-49) e Historia Universal de la Arquitectura (1849-52) (Peiró y Pasamar, 1996: 144 n. 66). A la vez, comenzó a asistir como alumno a clases de árabe, hebreo y griego en la Universidad de Madrid, por lo que debió ser alumno de Gayangos en árabe y García Blanco en hebreo.

Sobre la Arqueología Monumental publicó sus trabajos más representativos de este periodo, Apuntes sobre el origen y progresos de la Arquitectura (1846) y en particular, Álbum artístico de Toledo (1848), centrado en el arte visigodo y en la definición del arte mudéjar, sumándose a las corrientes románticas sobre Arqueología Monumental que había introducido Amador de los Ríos.

Sin embargo, aprovechando un viaje a Europa en el cual creó en San Petesburgo una sección de la Academia Española de Arqueología, estuvo en 1852 en París recibiendo clases de sánscrito en el College de France en París (Ruiz Cabriada, 1958: 122), impartidas por Théodore Pavie, profesor de esta asignatura entre 1852-57 y traductor parcial al francés de la Mahabharata. Al regresar a Madrid, ya con 40 años, a la vez que seguía ejerciendo la abogacía, pasó a impartir docencia en el Ateneo de Lengua y literatura sánscrita (1853-54) y Lengua céltica (1856-58), aunque sin dejar la Arqueología Monumental, impartiendo Arqueología Española (1854-56 y 1858-60) o redactando las Nociones fisionómico-históricas de la Arquitectura en España (1857), en el cual realizó una de las primeras síntesis sobre el megalitismo hispano, que valieron su nombramiento como Correspondiente de la Real Academia de la Historia el 5 de junio de 1857. También tuvo docencia gratuita de Lengua Sanscrita en la Universidad Central de Madrid durante dos cursos académicos 1856-58, autorizadas el 27 de junio de 1856 y el 16 de octubre de 1857 (Peiró y Pasamar, 1996: 144 n. 66), pero la aprobación de la Ley Moyano el 9 de septiembre de 1857 no dejaba hueco para estos estudios que hubieran requerido la creación de una cátedra extraordinaria. Es interesante la confluencia en Assas del interés por los megalitos que consideraba célticos y el estudio de su lengua, la cual también creía reconocer en la toponimia cántabra y gallega.

El hebraísta más importante del siglo XIX fue Antonio María García Blanco. Nacido en 1800 en Osuna (Sevilla), era hijo del médico y Catedrático de Filosofía en la Universidad de Osuna, Antonio García García, diputado liberal por Sevilla en las Cortes durante el Trienio Liberal. Finalizó el grado de Bachiller en Filosofía en 1817 y en 1818 obtuvo el de Maestro en Artes. Después se matriculó, también en la Universidad de Osuna, en la Facultad de Teología, donde cursó los 3 cursos entre 181821 (García Blanco, 1869; Rivière, 2000: 111-112).

Estimulado por su padre que para tener un buen conocimiento del Antiguo Testamento hacía falta una buena formación en hebreo, la "lengua de Dios", empezó a formarse con Pablo de la Llave que había sido desterrado en 1816 a Osuna por Fernando VII, después de haberlo encarcelado hasta 1815 por sus ideas liberales. Pablo de la Llave había impartido hebreo en Valladolid de Mechaocan, Nueva España, y durante el reinado de José Bonaparte había sido el Director del Real Museo de Ciencias Naturales, nueva denominación que recibió en 1815 el Real Gabinete de Historia Natural. Con el inicio del Trienio Liberal, Pablo de la Llave marchó a Madrid como vocal de la Junta Suprema de Censura y Diputado liberal por Veracruz. Sin profesor de hebreo y acabado su grado de Licenciatura en Teología, acompañó a su padre a la capital, matriculándose en el Colegio Imperial de los Reales Estudios de San Isidro entre 1821-23, donde tuvo de profesor de hebreo a Francisco Orchell y Ferrer, catedrático desde 1799 y maestro de Pablo de la Llave, y de griego a Antonio Colom (García Blanco, 1869: 483-486; Rivière, 2000: 112-113), la base del Nuevo Testamento.

Cuando debía ocupar como profesor sustituto la Cátedra de Hebreo de la Universidad de Granada en 1823, la vuelta al absolutismo por Fernando VII y la represión siguiente, hizo perder sus plazas al padre en Osuna y al hijo, retirándose ambos a tierras del Marqués de La Gomera. Con el paso de los años, ante la falta de salidas laborales, opositó a plazas de curato en 1827, obteniendo la de cura párroco de Valdelarco (Huelva) entre 1827-31, después de Écija (Sevilla) en 1832, retirándose a vivir a Sevilla hasta 1833 , por la epidemia de cólera, donde continuó estudios de Teología en la Universidad de Sevilla, consiguiendo por oposición la plaza de Magistral de la Santa y Real Capilla de San Fernando y entrar en la Universidad de Sevilla como profesor sustituto la Cátedra de Hebreo entre 1834-36 (García Blanco, 1869: 496497; Rivière, 2000: 114).

Diputado liberal a Cortes por Sevilla en Madrid desde el 2 de octubre de 1836, solicitó el traslado de su plaza a la Cátedra de Hebreo en el Colegio Imperial de los Reales Estudios de San Isidro, pero le fue concedida el 22 de octubre en 1837 en la 
Universidad Central de Madrid y en propiedad en 1850, a donde fueron trasladadas las cátedras de griego y hebreo, que detentó hasta 1858 y 1868 1877 (García Blanco, 1869; Rivière, 2000: 114$115,119)$.

El Consejo de Instrucción Pública le encargó la redacción de un manual de hebreo, Diqduq, Análisis filosófico de la escritura y lengua hebreas (1846-51), de 3 volúmenes, el primero sobre su morfología y el segundo sobre la sintaxis, en el que comenzó a trabajar al empezar a dar clases de hebreo en la Universidad de Sevilla en 1834.

Su apoyo a la desamortización en las Cortes de 1836, sus críticas a la iglesia por considerarse depositaria de la verdad bíblica y a la mala calidad de las traducciones de la Biblia le crearon grandes enemigos, llegando a ser definido como "tipo acabadísimo del clérigo progresista de 1837, revolucionario de sacristía" (Menéndez y Pelayo, 1967/2: 846), que fueron potenciando a un alumno de la Facultad de Filosofía y Letras, el conservador Severo Catalina del Amo, que pasó a desempeñar, con 26 años, interinamente, su Cátedra de Hebreo en la Universidad Central de Madrid entre 185868, después de pedir García Blanco, al no sentirse apoyado, la excedencia en 1858 para trabajar en Marchena (Sevilla) en un diccionario hebreo-español que dejó inacabado (Rivière, 2000: 121). La influencia de Severo Catalina continuó imparable siendo elegido Diputado por Alcázar de San Juan y Cuenca entre 1863-68, Director General de Instrucción Pública, luego Ministro de Marina, del 13 de febrero al 23 de abril de 1868 con Narváez, y finalmente Ministro de Fomento entre abril y septiembre de 1868 con González Bravo. Su exilio con la reina Isabel II, representándola ante el Papa en Roma, dejó vacante la Cátedra de Hebreo en la Universidad Central, lo que facilitó el regreso de García Blanco a su plaza, donde permaneció desde 1868 hasta su jubilación el 28 de abril de 1877, ya con 77 años, regresando a Osuna en 1883 y falleciendo en 1889. Severo Catalina no regresó a España hasta 1871, ya enfermo, durante el reinado de Amadeo I de Saboya, y falleció en septiembre de 1871.

\section{De Manuel de Góngora a Manuel RODRÍGUEz DE BERLANGA, LA EVOLUCIÓN EN EL ESTUDIO DE LA EPIGRAFÍA ROMANA}

Debido a la pérdida de nivel en los estudios de epigrafía romana durante el siglo XIX en España, se creó un notable vacío que fue ocupado por Emil Hübner, aprovechando también el bajo nivel de la Historia Antigua en España, terreno virgen a la llegada de Schulten. Se rompía con la tradición del siglo XVIII cuando el Marqués de Valdeflores, llegó a recopilar 4.000 fichas para una catalogación de todos los epígrafes romanos de la Península Ibérica (Canto y de Gregorio, 1994 y 2003: 43), del proyecto del Conde de Campomanes (Canto y de Gregorio, 2003), y los intentos de continuación por el Conde de Lumiares para el País Valenciano, Inscripciones y Antigüedades del reino de Valencia (1800/1852), que también proyectó ampliarla para toda España, y finalmente por Candido María Trigueros, quien recopiló más de 600 fichas epigráficas para su proyecto de Inscripciones geográficas antiguas de España (Mora, 1988: 345). Para esta etapa es interesante contrastar dos formas de trabajar en Manuel de Góngora y Martínez y Manuel Rodríguez de Berlanga y Rosado.

El trabajo de Manuel de Góngora responde a la tradición de los viajeros ilustrados del siglo XVIII, que tuvo un relanzamiento con las corrientes románticas en la primera mitad del siglo XIX, aunque sus obras aparecieron en la transición a una nueva época, que ya marca la década de los años sesenta. No deja de sorprender en Antigüedades de Andalucía (Góngora, 1868) el cuidado gráfico del trabajo que ha sido básico para su recepción moderna, con 5 fotógrafos diferentes de Granada, Albuñol, Málaga y Jaén y 3 dibujantes de Granada, Jaén y Madrid, fundamental para acompañar el relato. Sin embargo, si vemos los trabajos de Góngora como libros de arqueología y no de literatura de viajes con información arqueológica, salen a relucir sus defectos como la ausencia de datos contextuales e interpretación de los hallazgos, que en su hallazgo principal para la Prehistoria, la Cueva neolítica de los Murciélagos de Albuñol (Granada), ha pasado a un segundo plano porque había sido saqueada previamente, consiguió recuperar un gran número de piezas conservadas por su donación en el Museo Arqueológico Nacional y sus contemporáneos tenían todavía pocos elementos de juicio para valorar los hallazgos prehistóricos.

Otra cuestión fueron sus investigaciones epigráficas, con una larga tradición desde el siglo XVIII, de la que tenía escasos conocimientos. Aunque llegó a aportar nada menos que 91 inscripciones inéditas al CIL (de Mengibar, Arjona, Isturgi, Mentesa Oretanorum, Santiesteban del Puerto, Baños, Vilches, Bailén, Castulo, Baeza, Puente Quebrada, Toya, Mancha Real, Jaén, Alcaudete, Salaria, Tugia, Iliturgicola, Iliberris, Cabra, Baena, Guadix y Mentesa), fruto de un enorme esfuerzo de trabajo de campo, como señala Baena del Alcázar (2003: 370, 372 n. 41) "el pobre conocimiento que de la epigrafía tenía Góngora, que yerra de continuo en sus interpretaciones", y sugiere la clave del problema, "El desconocimiento, aún mayor que él de Góngora en estas materias, de las personas encargadas de valorar su trabajo", concretamente Aureliano Fernández-Guerra, que "no dudaron en 
calificarlas muy por encima de su valor, otorgando premios y prebendas al autor, cuya fama, traspasando los ámbitos académicos y universitarios, pasó al dominio público gracias a la propaganda de la prensa" como criticaba Rodríguez de Berlanga (1861b/V: 1). En su afan coleccionista, buena parte de esas inscripciones las trasladó, con notables costes por su peso y procedencia, a su vivienda, primero en Jaén y luego en Granada, depositándolas en la Universidad, comentando en 1868 sobre "mi colección de antigüedades, mis preciosas inscripciones, que ascienden casi al número de quinientas" (Góngora, 1868: 6), muchas de ellas también en lengua árabe.

Manuel de Góngora nació en Tabernas (Almería), el 13 de enero de 1822, hijo de Francisco de Paula Góngora Palacios de Gérgal (Almería) y María Josefa Martínez de Haro, de Tabernas. Aunque no conocemos la profesión del padre debía tener estudios pues sus tres hermanos estudiaron también, Juan Antonio, profesor de la Facultad de Derecho; Rafael, profesor de la Facultad de Medicina, que le acompañó en prospecciones por Jaén y Granada, y José María, que acabó Derecho en 1873. Empezó estudiando los 3 años de Bachiller de Filosofía en el Seminario Conciliar de San Indalecio de Almería entre 183437. De allí pasó la Universidad de Granada para cursar los 7 años de la Licenciatura en Derecho cuyos estudios terminó el 14 de octubre de 1844, comenzando a ejercer como abogado desde mayo de 1845 a los 23 años, que debió simultanear con los de Filosofía y Letras que terminó el 13 de noviembre de 1845 . No dejó sus estudios y cursó después la Licenciatura de Ciencias Naturales que terminó el 14 de octubre de 1849. Paralelamente ejerció la docencia, primero de Historia en el Colegio Privado de Nuestra Señora de las Angustias de Granada, agregado al Instituto, desde el 20 de septiembre de 1847 y después como Profesor Agregado, sin sueldo, en la Facultad de Filosofía y Letras entre el 7 de diciembre de 1847 al 29 de agosto de 1850 (Pastor y Pachón, 1991: XV-Xviii).

En Granada debió conocer a Aureliano Fernández-Guerra, pues pudieron coincidir en el curso 1837-38 el primero de Góngora en Granada y el último de Fernández-Guerra, o también después hasta que a finales de 1842 se trasladó a Madrid. En todo caso, se trataron en la tertulia del Liceo de Granada, como recuerda propio Góngora (1870b), a la que acudía José de Castro, Marqués de Gerona, pero también Aureliano y José Fernández-Guerra, Javier de Burgos, Francisco Martínez de la Rosa, etc., colaborando todos en el periódico La Alhambra.
Acabados sus estudios en 1849, Góngora fue nombrado fiscal de la Subdirección de Rentas en Algeciras (Cádiz) entre el 27 de noviembre de 1850 y el 1 de abril de 1851, volviendo a Granada el 27 de junio de 1851 a la Tesorería de Hacienda Pública de Granada hasta el 12 de marzo 1853. Ese año obtuvo una plaza de Catedrático de Latinidad y Humanidades en el Instituto de Ávila el 18 de agosto de 1853 (Pastor y Pachón, 1991: xviii-xix), pero por mediación del granadino, José de Castro y Orozco, Marqués de Gerona (Góngora, 1868: 3), obtuvo un rápido traslado a la Cátedra de Geografía e Historia en el Instituto de Jaén, donde se incorporó el 1 de septiembre, a los 31 años.

El padre de José de Castro, con su mismo nombre, era el Decano del Colegio de Abogados de Granada, mientras que su hermano menor de José de Castro, Francisco de Paula Castro y Orozco había sido Ministro de Gracia y Justicia en 1838 y Presidente del Congreso entre 1845-47. José de Castro, licenciado en Derecho en 1818, fue Presidente de la sala primera de la Audiencia de Granada desde 1843 y Rector de la Universidad entre 1843-46, pasó luego a la Audiencia de Sevilla y fue elegido Ministro de Gracia y Justicia en 1858. No todo fueron éxitos y vio primero morir a su esposa y después a su único hijo en 1863 (Góngora, 1870b). A él le escribe la carta introductoria del libro de Antigüedades de Andalucía, justificando la obra (Góngora, 1868: 3-6), lógica dentro del sistema clientelar que ha caracterizado la España del siglo XIX y XX.

En Jaén casó con Amalia del Carpio del Castillo, a la que le dedicó el libro de Antigüedades de Andalucía, hija del Juez de Primera Instancia, Juan José del Carpio, con la que tuvo 4 hijos, Fernando, que falleció y al que le dedicó sus Nociones de Historia Universal en 1879 y le acompañaba a veces en sus prospecciones (Góngora, 1868: 42-43), Francisca, Mercedes y el pequeño, Francisco de Paula de Góngora y del Carpio (Baena del Alcázar, 2003: 359, 374), que recuperó el nombre de su abuelo, primer director del Museo Provincial de Granada, desde su fundación el 21 de noviembre de 1879 hasta su muerte en 1919.

Sus años en Jaén entre 1853-58, con una edad entre 31 y 36 años, van a ser los de más intensas prospecciones, que plasmó en su primer libro, cuyo título recoge el espíritu de su obra, Viaje literario por las provincias de Granada y Jaén (Góngora, 1860/1915-16), y donde también ya se observa el cuidado en la parte gráfica como han destacado Maier y Salas (2007: 196, 199), colaborando el fotógrafo Genaro Giménez con 37 imágenes o el Ayudante de Obras Públicas, Baltasar del Prado, para levantar los planos de los despoblados de 
Cástulo, Giribaile y Silpia, detallismo que posteriormente encontramos en Antigüedades de Andalucía.

Dificilmente puede ser una coincidencia que siendo José de Castro, Ministro de Gracia y Justicia desde el 21 de septiembre de 1858, ese año Manuel de Góngora y Martínez consiguiera el traslado de su cátedra de Instituto al de Catedrático interino de Historia Universal en la Universidad de Granada, por Real Orden el 30 de septiembre de 1858 (Pasamar y Peiró, 2002: 310), nueva asignatura creada en el plan Moyano de 1857 para tercer curso. Se ha señalado que la medida partió de Fernández-Guerra, por entonces Secretario del Consejo de Instrucción Pública (Pastor y Pachón, 1991: xx; Maier y Salas, 2007: 197), pero resulta más lógico que fuese una decisión del propio ministro, justo después de acceder al cargo, que debía saber que la cátedra estaba vacante pues era el ex-rector de la institución. Debe tenerse en cuenta que desde 1852, el Ministerio de Gracia y Justicia había asumido la Dirección General de Instrucción Pública.

Para poder detentar una cátedra tenía que tener una tesis doctoral en Filosofía y Letras, lo que realizó el 8 de mayo de 1860 en la Universidad Central de Madrid, con un tema de Historia Medieval, Espíritu y hechos generales determinantes de las Cruzadas: modificaciones de aquel espíritu desde la Primera Cruzada a las últimas, e influencia de este hecho histórico en la civilización (Góngora, 1860). Una vez leída, fue nombrado por concurso Catedrático de Historia Universal en la Universidad de Granada el 27 de julio de 1860 y tuvo como acumulada, entre 1862-67, la de Historia de España (Pastor y Pachón, 1991: xx-xxi).

Sí que fue fundamental la labor de FernándezGuerra, Numerario de la Real Academia de la Historia desde el 7 de diciembre de 1855, para su nombramiento el 29 de abril de 1859 como Inspector de Antigüedades de Granada y Jaén, las dos provincias que mejor conocía, con una gratificación de 2.000 reales (Pachón y Pastor, 1991: xxi) y en la concesión del Premio por descubrimiento de Antigüedades, en su segunda edición de 1860, iniciativa de Fernández-Guerra, por una comisión formada por Fernández-Guerra, Gayangos y Salustiano de Olózaga para los calcos de inscripciones romanas y árabes y otra formada por Delgado, Fernández-Guerra, Gayangos, Olózaga y José Caveda para el manuscrito del Viaje Literario, con un premio de 8.000 reales (Maier y Salas, 2007: 199 n. 34). El premio suponía también el nombramiento como Correspondiente de la Real Academia de la Historia de Góngora.

Como puede apreciarse, en el informe sobre las inscripciones, el experto en inscripciones latinas se suponía que era Fernández-Guerra, mientras que en las árabes se trataba de Gayangos. El problema surgió cuando Hübner vino a Granada a consultar las inscripciones y pudo estudiar parte de ellas. Acababa de estar en Málaga, después de anunciarle Mommsen su visita el 15 de abril, donde llegó el 16 de agosto y conoció personalmente a Rodríguez de Berlanga (1864: 517 y 1901: 192), quien lo acompañó en algunas de sus visitas, pero al estallar un brote de cólera en Málaga, decidió quedarse con la familia Loring y no lo acompañó a Antequera y Granada como tenía previsto. Aunque Hübner estuvo en Granada entre finales de agosto e inicios de septiembre no pudo extrañamente encontrarse con Góngora (1868: 4), que era además el Inspector de Antigüedades, según indica éste, "no [lo] encontré ya en los puntos a donde varias veces me dirigí deseoso de conocerle".

También Rodríguez de Berlanga vino a Granada a conocer las inscripciones, primero en julio de 1860 y después avanzado septiembre de 1860, y sí pudo encontrarse con Góngora quien le prestó su manuscrito, "una tarde y una noche" (Rodríguez de Berlanga, 1861b: $112 \mathrm{n}$.) e hizo calcos detallados de todas sus inscripciones que había depositado en la Universidad de Granada, algunos en julio y con detalle de todos en septiembre. Pensando que se publicaría el texto de Góngora, lo comentó en uno de sus textos de Estudios Romanos, que además dedicaba a Hübner. La razón, en parte, era la divulgación a la prensa de los resultados del trabajo, "Los periódicos tenían anunciado con repetición que con ellas se había descubierto el asiento de varios pueblos antiguos, entre los cuales se hacían figurar algunos hasta el día desconocidos" (Rodríguez de Berlanga, 1861b/V: 1). El fondo de su crítica no era contra Góngora, sino iba más arriba, en principio contra la Universidad de Granada, donde se había formado, por "que en una universidad española ha visto destinada las cloacas para tener en ellas las inscripciones" cuando la vió por primera vez en julio de 1860 y allí seguían en septiembre (Rodríguez de Berlanga, 1861b/V: 2).

Pero el objetivo último de sus críticas era la Real Academia de la Historia y en particular Fernández-Guerra por su ignorancia epigráfica. Como indica "El Viaje literario tiene todo el carácter de un libro puramente geográfico, de modo que su autor no traduce, explica, ni comenta ninguna inscripción (...) Sin embargo, colijo que los partidarios de distinto sistema, han de estimarlo en mucho, visto los elogios que le ha tributado la Real Academia de la Historia" (Rodríguez de Berlanga, 1861b/V: 4). Por ello, indica que frente a la opinión de "la Real Academia de la Historia (...) me he permitido significar que siento mucho no poder 
adoptar las opiniones epigráficas comprendidas en aquel. He trasladado literalmente las expresadas en la Noticia de las actas de la Academia y las de Góngora que son las mismas, poniendo con ello en relieve mi atrevimiento, al no aceptarlas, viniendo de sujetos tan competentes" (Rodríguez de Berlanga, 1861b/V: 116). La correspondencia entre Fernández-Guerra y Rodríguez de Berlanga tiene su final con el envío del facsímil de Aeris malacitani (1861a), aunque Olmedo (2000: 41-42) cita alguna carta en 1863. En otra carta de Rodríguez de Berlanga a Riaño de julio de 1886, define a Fernández-Guerra como "el sabio folletinista de hopalanda (que ignoro haya escrito sino tan solo unos folletos sobre todas las cosas y otras muchas más...)" (Olmedo, 2000: 100-101).

Su intención era cubrir "el vacío que se nota en el libro ya citado respecto de la parte epigráfica (...) cuanto por hacer ver a su autor lo mucho en que estimo sus descubrimientos" (Rodríguez de Berlanga, 1861b/V: 4). Recalcaba al final que este conjunto lo "ha fotografiado y recogido D. Manuel de Góngora, a cuyo celo e infatigable laboriosidad se debe que hayan sido conocidos estos monumentos, que forman una de las más preciosas colecciones epigráficas de nuestra España" (Rodríguez de Berlanga, 1861b/V: 115). Acabado su trabajo comentando las 26 inscripciones del Viaje Literario en noviembre de 1860, remitió su opinión a Hübner, quien una vez consultó el texto de Góngora en la Real Academia de la Historia le envió dos cartas con sus comentarios el 13 de febrero y el 14 de marzo de 1861, cuyas opiniones incluyó Rodríguez de Berlanga (1861b/V: 5 n. 1), como notas, dentro del texto.

Hübner había escrito previamente a Rodríguez de Berlanga para que le confirmara problemas que habían tenido en la lectura de algunas inscripciones, "La obra del Sr. Góngora no ha podido V. manejarla (...) y además sobre varias de las inscripciones de la universidad me pregunta mi opinión" (Rodríguez de Berlanga, 1861b: 3-4), lo que decidió a éste a redactar un texto detallado. De vuelta a Madrid, Hübner consultó el manuscrito en la Real Academia de la Historia donde dejó "la enmienda, que en muchos parages hizo de su propio puño" (Góngora, 1868: 4), y las comenta en alemán en sus Epigraphische Reiseberichte (Hübner, 1861: 26-50).

Aunque es criticable que Rodríguez de Berlanga no esperase a la publicación del texto de Góngora (1868: 4), tampoco lo hizo Hübner, aunque a éste no lo critica por su relación con Fernández-Guerra. Es posible que la premura de Rodríguez de Berlanga fuera por Hübner y no por Góngora, como se ha pensado, que no lo trataba ni podía interpretarlas. Sin embargo, no es correcta la opinión de Góngora que Rodríguez de Berlanga publicó su trabajo "Enterado de los reparos del doctor Hübner, publicó un largo trabajo combatiendo el mío", pues Rodríguez de Berlanga redactó el suyo primero, porque pudo consultar meses antes tanto el libro inédito de Góngora y realizó también antes la inspección ocular de todas las inscripciones, y su comentario ya estaba redactado antes de que Hübner consultase el texto de Góngora (Rodríguez de Berlanga, 1861b/V: 5 n. 1). Sí tiene razón cuando afirma que al adelantarse Rodríguez de Berlanga, como el propio Hübner, su trabajo perdió parte de su valor, "Conocidas las inscripciones y lo útil de mi trabajo, éste había perdido completamente su mayor importancia. Formé entonces un nuevo propósito (...) la de hacer mayores descubrimientos; y en tal manera, que las inscripciones del trabajo nuevo fuera en tanto número, que superasen fabulosamente las del antiguo" (Góngora, 1868: 5), aunque el Viaje literario tiene otros méritos y fue una lástima su no publicación, pues el estudio epigráfico lo complementaba, aunque ponían en evidencia algunas de sus prematuras interpretaciones sobre el emplazamiento de algunas ciudades antiguas como Unininita en Alcalá o Campaneana en El Campanil, que también divulgó en la prensa. Lo que debió hacer era una revisión del Viaje literario con los nuevos datos, mejorándolo, ya que aún no se había publicado, y no paralizar su impresión.

A pesar de la actitud crítica de Baena del Alcázar (2003: 370) con Rodríguez de Berlanga, que considera "injustificada y reprobable", reconoce "la infinita ciencia de Berlanga, que contrasta, por el contrario, con el pobre conocimiento que de la epigrafía tenía Góngora, que yerra de continuo en sus interpretaciones". Por su parte, Maier y Salas (2007: 199) creen que Rodríguez de Berlanga publicó las inscripciones inéditas de Góngora "en connivencia con Hübner".

El carácter perfeccionista y muy crítico de Rodríguez de Berlanga lo aplicaba consigo mismo y con todo lo que leía, como refleja una carta suya de 1897, "En mi deseo de no lastimar a nadie, ni aún ligeramente, he rehecho tres veces mi trabajo y aún así no me he decidido a publicarlo sino después de haber mediado sinceras y afectuosas explicaciones con un amigo a quien respeto y admiro, pero cuya opinión sobre el iberismo no es precisamente la mía" (Olmedo, 2000: 93).

Aureliano Fernández-Guerra siguió progresando en la Real Academia de la Historia, primero como Anticuario en funciones en 1866, después Anticuario interino desde 3 de mayo de 1867 y finalmente Anticuario por elección el 6 de diciembre de 1867. Su estrategia futura fue apoyar el trabajo de Hübner, movilizando a los corresponsales, 
siendo Góngora uno de los más constantes, frente a su compatriota malacitano, su más peligroso competidor en Andalucía y España.

En Granada, aunque se suprimió en 1865 el puesto de Inspector de Antigüedades de Granada y Jaén y la remuneración económica que suponía, Góngora pasó a integrarse en la reformada Comisión Provincial de Monumentos de Granada desde el 20 de marzo de 1866, de la que llegó a ser vicepresidente hasta su muerte en 1884 y que presidía el Marqués de Gerona, José de Castro (Pastor y Pachón, 1991: xxviii), siempre interesado en la arqueología, como evidencia su estudio de la necrópolis de Atarfe, Sierra Elvira (Marqués de Gerona, 1843). En esta década, fue un notable miembro de la tertulia de La Cuerda granadina, al igual que Bonifacio Riaño.

En la edición de 1867 del Premio por descubrimiento de Antigüedades, con un jurado formado por Fernández-Guerra y Pedro de Madrazo, su trabajo volvió a ser premiado por la Real Academia de la Historia cuando localizó una inscripción que identificaba la colonia Salaria en Úbeda la Vieja (Góngora, 1867), aunque su interpretación fue corregida por Hübner (1869: $\mathrm{n}^{\mathrm{o}} 5093$, 950). Premiaba el objetivo último de las prospecciones de Góngora, la localización de epígrafes con nombres de ciudades citadas en las fuentes clásicas que dieran nombre a algunos grandes despoblados ya entonces conocidos.

Su afición como coleccionista de monedas también le creó estrechas relaciones con otro coleccionista, el Numerario Serafín Estébanez Calderon, tío segundo de Cánovas del Castillo, como se aprecia en una carta de 1866, "En cuanto a las justas pretensiones del señor Góngora ya le he dicho a [Fernández-]Guerra que le ayudaré en sus buenos oficios a favor de ese buen amigo" (GómezMoreno, 1953: 235).

En su segundo libro, Antigüedades de Andalucía, decidió compensar los sinsabores que le había deparado el primero, por "empeño de honor y de dignidad. No pudiendo ya publicar mi libro, debía compensarlo con otro (...) desde entonces me he consagrado a mi propósito, sin reparar en los gastos y en los sacrificios que me imponía (...) resintiéndose mi fortuna gravemente; siéndome forzoso desprenderme de mis libros, de mi monetario, de cuanto podía enajenar, y hasta de la única finca que heredé" (Góngora, 1868: 5-6).

No faltaron críticas también a este trabajo, en particular de Antonio Machado y Núñez, Catedrático de Historia Natural en la Universidad de Sevilla, por la ausencia de datos estratigráficos del material de la Cueva de los Murciélagos de
Albuñol que "imposibilitaron el conocimiento de la superposición de los objetos; y al ofrecerlos todos en conjunto, descritos aisladamente y representados con láminas, no pueden deducirse legítimas consecuencias de su antigüedad y colocación geológica, o de su cronología positiva", por lo que "la obra del Sr. Góngora produce una impresión desagradable y un doloroso sentimiento" (Machado, 1869: 38).

En la década de los setenta fue reduciendo su producción científica en Prehistoria, a pesar de sus iniciales intenciones de continuar con una segunda parte de Antigüedades de Andalucía que indicaba en la dedicatoria a su mujer, pues se trataba de "la primera parte de mis empresas literarias", pero después sólo publicó algunos breves trabajos (Góngora, 1870a y 1881). Sus esfuerzos de dirigieron más a elaborar manuales universitarios de las asignaturas que impartía o había impartido, Lecciones de Historia Universal y particular de España (1878/1882) y Nociones de Historia Universal y de España (1879/1880), Nociones de Historia General de España (1880/1882) у Nociones de Geografía (1881b).

Los donativos que hizo al Museo Arqueológico Nacional de parte de su colección en septiembre de 1869 y agosto de 1871 (Pastor y Pachón, 1991: xxix), poco después de la creación del museo en 1867 y aún sin inaugurar, a partir de los 47 años, son indicativos de su progresiva retirada de la prehistoria y romanización. En la Universidad de Granada alcanzó el puesto de Decano interino desde el 7 de enero al 24 de septiembre de 1869 y de nuevo del 13 de junio de 1870 hasta el 28 de marzo de 1873, cuando fue nombrado Decano en propiedad, manteniéndose en su cátedra y decanato hasta su muerte en Madrid, el 10 de abril de 1884 (Pastor y Pachón, 1991: xxi), con sólo 62 años.

El mejor epigrafista español del siglo XIX fue Manuel Rodríguez de Berlanga y Rosado, ya junto con el padre Fidel Fita en el último cuarto de siglo. Aunque no dispuso de una plaza universitaria, sí contó con el apoyo continuado de un industrial, coleccionista de antigüiedades, el Marqués de la Casa-Loring, en la entonces segunda provincia más industrial de España que llegó a ser Málaga.

Nació en Ceuta el 25 de diciembre de 1825 y falleció el 3 de junio de 1909 en Málaga. Era el mayor de tres hermanos, Mauricio que murió con 6 años y su hermana pequeña Dolores, nacida en 1837. Hijo del Director del Real Hospital Militar, Manuel Rodríguez de Berlanga y Lasseletta y Rafaela Rosado y Hudson, en una familia de tradición militar pues su abuelo, Mauricio Rodríguez de Berlanga y Giménez había sido Mariscal de campo. Pasó a vivir con la familia a Málaga hacia 
1840 , quizás al tener que comenzar ya los estudios. Realizó los 3 años de estudios de Bachillerato en Filosofía en el Seminario Conciliar de Málaga entre 1840-43, pasando a estudiar Derecho en la Universidad de Granada donde licenció en 1850 (Olmedo, 1985: 71-72 y 2000: 15, 17), con 25 años. Como puede observarse, sólo pudo haber coincidido con Góngora en la Facultad en el curso 1843-44, Rodríguez de Berlanga en su primer año y Góngora en su útimo curso.

Dado de alta como abogado en Málaga, marchó a la Universidad Central de Madrid para realizar su doctorado en Derecho Romano en Madrid (1852), Discurso sobre el Derecho Internacional Privado de Roma desde sus primeros días hasta la destrucción del Imperio de Occidente, dirigida por el Marqués de Morante, Joaquín Gómez de la Cortina y Gómez de la Cortina, entonces Rector de la Universidad de Madrid.

Al acabar la tesis doctoral, pensó opositar a una Cátedra universitaria de Derecho Romano, como recuerda en una carta de 1899 , "recién doctorado quise probar fortuna y me lo quitaron de la cabeza dos madrileños amigos de mi padre, senador el uno y director general el otro. Cuando averiguaron que las tres o cuatro cátedras de Derecho Romano que salían a la oposición que quería firmar todas estaban dadas antes de los ejercicios por la modesta suma de mil duros cada una" (Olmedo, 1985: 76).

Estimulado por su director de tesis, al enterarse que habían aparecido dos tablas de bronce con las leyes municipales de Malaca y Salpensa, Lex Flavia Malacitana y Lex Salpensa, a inicios de octubre de 1851 en Las Olletas, Barranco de los Tejares (Málaga), mientras se extraía barro, entró en contacto con su comprador en noviembre de 1852, Jorge Loring Oyarzábal, al que conoció en la tertulia que se celebraba en la biblioteca de los hermanos Oliver Hurtado. Manuel, al que debió conocer en la Universidad de Madrid pues se licenció en Derecho en octubre de 1853, y de José Oliver Hurtado, futuro Obispo de Pamplona, tertulia a la que asistía también Antonio Cánovas del Castillo, que en 1854 fue elegido Diputado por Málaga de la Unión Liberal y marchó a Madrid.

Jorge Loring, ingeniero de caminos, canales y puertos y director de la construcción del ferrocarril Málaga-Córdoba, hijo de un emigrante norteamericano, Jorge Loring James, estaba interesado en las antigüedades no sólo por propio interés sino también por influencia de su mujer, Amalia Heredia Livermoore, pues su suegro, el rico comerciante, Manuel Agustín Heredia, era miembro de la Comisión Provincial de Monumentos de Málaga desde su creación en 1844 (Olmedo, 2000: 44-45) y coleccionista en su Finca de San José, mientras que el tío político de Amalia era el también coleccionista, Marqués de Salamanca (Baena del Alcázar, 1988).

Preparó su publicación entre noviembre de 1852 y enero de 1853, Estudios sobre los dos bronces encontrados en Málaga a fines de octubre de 1851 (Rodríguez de Berlanga, 1853), que mereció también un detallado estudio de Theodor Mommsen (1855), aunque no faltaron autores como Laboulaye (1856) que sugirió su posible falsificación poniendo el refrán, "De las cosas más seguras, la más segura es dudar”. Su carácter perfeccionista y crítico con su propio trabajo se refleja al describir pocos años después en una carta este libro a Fernández-Guerra, "Mi primer opúsculo (...) [fue] escrito en un momento de entusiasmo y plagado de defectos, hijos unos de la precipitación y otros de mi ignorancia".

En 1855 entraron en la Comisión Provincial de Monumentos, Rodríguez de Berlanga como secretario y José Loring como vocal (Olmedo, 2000: 45). Miembro ya de la Comisión Provincial, fue propuesto como Correspondiente de la Real Academia de la Historia por el malagueño Serafín Estébanez Calderon, tío político de la Marquesa de Casa Loring y tío segundo de Cánovas del Castillo, junto con Amador de los Ríos, Fernández-Guerra y Olózaga el 29 de mayo de 1857 y nombrado el 26 de junio (Rodríguez Oliva, 1991: 100). Por su parte, por su labor en la construcción el ferrocarril de Málaga-Córdoba, inaugurado en 1859, Jorge Loring recibió el título de Marqués de Casa-Loring en abril de 1856. Ese año se creó el Banco de Málaga por tres inversores, Jorge Loring, Tomas Heredia y Manuel Larios y Larios, Marqués de Larios, y Rodríguez de Berlanga pasó a ser el secretario del banco en mayo de 1856. Hasta entonces, además de abogado, había ejercido de fiscal suplente en Málaga del Juzgado del distrito de la Merced desde 1854. El permanente contacto con la familia Loring favoreció que coincidiendo con la desaparición del Banco de Málaga en 1874, absorbido por el Banco de España, se casase con la hermana de Jorge Loring, Elisa Carolina Loring Oyarzábal, el 8 de noviembre de 1874, aunque dejó de trabajar como secretario del banco en 1872 (Olmedo, 1985: 73, 75 y 2000: 50-51).

Por entonces, Jorge Loring solicitó en mayo de 1858 a la Dirección General de Instrucción Publica de autorización para realizar excavaciones arqueológicas en la provincia de Málaga, lo que impulsó la elaboración de una Ley de Excavaciones y Antigüedades (Tortosa y Mora, 1996: 203), que nunca se aprobó. La razón debía estar en el descubrimiento del mosaico de los doce trabajos de Hercules en marzo de 1858 en la calle de la Concepción de Cártama (Málaga), que compró 
Jorge Loring, cuya excavación decidió ampliar para recuperarlo completo y duró hasta diciembre de 1858 (Berlanga, 1861b/II: 15-16, 56 fig.).

En estos años, Rodríguez de Berlanga (1858 y 1859) preparó una edición facsímil de la Lex Salpensa, que le obligó a rectificar su primera traducción y después otra edición facsímil de la Lex Flavia Malacitana (Rodríguez de Berlanga, 1861a). Entre medio, se publicaron los cinco Estudios romanos (Rodríguez de Berlanga, 1861b), el último de los cuales incluye la polémica con Góngora, que encubre su enfrentamiento con Fernández-Guerra.

En 1863 va a publicar su trabajo más elaborado, de 574 páginas, el estudio de todas las inscripciones romanas del municipio de Málaga, del que publicó una segunda edición revisada al año siguiente, Monumentos históricos del Municipio Flavio Malacitano (Rodríguez de Berlanga, 1863 y 1864), fue nombrado Vicepresidente de la Comisión Provincial de Monumentos el 5 de diciembre de 1866 (Olmedo, 2000: 45) y se centró en el Catálogo de algunas antigüedades reunidas y conservadas por los Excmos. Señores Marqueses de Casa-Loring en su Hacienda de la Concepción (Rodríguez de Berlanga, 1868).

\section{LOS PRIMEROS AROUEÓlOGOS EUROPEOS DESDE 1860: EDOUARD DE VERNOUIL, LOUIS LARTET Y EMIL HÜBNER}

Desde la década de los años treinta empezó a hacerse notar la presencia de compradores de arte y antigüedades extranjeros. La desamortización de bienes eclesiásticos fue el detonante y así el rey de Francia, Luis Felipe de Orleans, envió al Barón Taylor y el pintor Dauzats para comprar cuadros españoles destinados a su galería española en el Museo del Louvre entre 1838-48, que después le fue devuelta tras la pérdida del trono y su exilio en Londres, donde la vendió en 1852 (Delauny, 1997: 101, 106 n. 3).

El intento de venta al British Museum del Disco de Teodosio, que se consiguió deshacer el trato pagando 27.500 reales en 1847 (Tortosa y Mora, 1996: 200; Maier, 2008: 177-178). Después, la venta de 8 coronas y 5 cruces de Guarrazar al Museo de Cluny en febrero de 1858 por 72.000 reales, no se pudo impedir a pesar de las presiones diplomáticas y al joyero José Navarro, que trató de romper su acuerdo, pues el museo ya tenía las piezas (Balmaseda, 1996). Ambos casos son indicativos por una parte del desamparo legislativo, pero por otra de la ausencia de suficientes recursos para ir comprando de forma regular las piezas más importantes localizadas en hallazgos ocasionales.
Los investigadores extranjeros fueron cubriendo los vacíos que dejaba el sistema universitario y académico español en el campo de la arqueología, los cuales ya empezaron a llegar, con una buena formación universitaria como Emil Hübner, a inicios de los años sesenta. Es significativo que el mejor epigrafista español contemporáneo suyo, Rodríguez de Berlanga, no consiguiese una plaza cuando intentó acceder a la universidad en la especialidad de Derecho Romano y trabajó como secretario del Banco de Málaga.

Para la Prehistoria, Edouard de Vernouil y de Louis Lartet acompañaron a Casiano del Prado durante la primera identificación de útiles paleolítico en las terrazas de San Isidro en 1862 (Verneuil y Lartet, 1863). Cuando fueron en la primavera de 1862 a San Isidro, "M. de Verneuil fue el que se adelantó a preguntar a los trabajadores que allí se ocupaban, si no había salido alguna piedra particular. El principal de ellos dijo que sí, y nos llevó a su choza a que viésemos las que tenía separadas, que no eran pocas. Una de ellas era un sílex de los que deseábamos hallar, y se lo pagamos, tirando las demás" (del Prado, 1864: 190).

Esto fue casi coetáneo a los primeros hallazgos europeos, que comenzaron a ser aceptados mayoritariamente desde 1859, cuando Joseph Prestwich (1860), futuro catedrático de Geología de Oxford desde 1874, y John Evans visitaron las graveras de Menchecourt-les-Abbeville y Saint Acheul (Somme, Picardía, Francia) en 1859, para confirmar la coexistencia de mamíferos extinguidos y restos humanos que había publicado previamente Jacques Boucher de Perthes (1847 y 1860) y Jean Paul Rigollot (1854). Su confirmación permitió aceptar los hallazgos de Kents Cave (Torquay, Devon, Inglaterra), excavados por William Pengelly (184950) y Edward Vivian entre 1846-58.

La Historia Antigua fue otra disciplina que se consolidó en Europa a partir de los trabajos de Theodor Mommsen, director del Corpus Inscriptionum Latinarum (1853-), iniciativa alemana que competía con otro proyecto francés, y cuya obra más representativa es la Historia de Roma (1854-56), en 3 volúmenes. Después accedió a la Cátedra de Historia Romana de la Universidad de Berlín entre 1861-87.

Uno de sus discípulos fue Emil Hübner, nacido en la ciudad prusiana de Düsseldorf, el 7 de julio de 1834, hijo del pintor Julius Hübner, director de la Galería Real de Düsseldorf y de Pauline Bendemann, y muerto en Berlín el 21 de febrero de 1901. Estudió bachillerato en el Gymnasium de Dresde e inició sus estudios en la Universidad de Berlín, acabándolos en Bonn, donde se doctoró en 1854 con Quaestiones onomatologicae latinae, dirigida por Friedrich Ritschl. Una vez habilitado en 
la Universidad de Berlín en 1859, con De senatus populique Romani Actis, alcanzó el puesto de Profesor Extraordinario en 1863, pasando luego al de Profesor Ordinario o Catedrático en Filología Clásica en 1870. Como editor de revista participó primero en Hermes, Zeitschrift für Klassischen Philologie Revista de Filología Clásica- entre 1866-81 y paralelamente en el Archaeologische Zeitung -Noticiario Arqueológico- entre 1868-72 (Tormo, 1947: 491492; Stylow y Gimeno, 2004: 333).

Después de formarse en Italia entre 1856-58 con el epigrafista Bartolomeo Borghesi, recorrió España entre marzo de 1860 y octubre de 1861, que recoge en su Epigraphische Reisberichte aus Spanien und Portugal -Viaje epigráfico por España y Portugal- (1860-61), para elaborar el Corpus de Inscriptiones Latinae II. Inscriptiones Hispaniae Latinae (1869) de la Península Ibérica, del que posteriormente editaría un suplemento, que le obligó a regresar a España en 1881, 1886 y 1889, actualizándolo con las nuevas inscripciones (Hübner, 1892). Durante su estancia en España pensó publicar un artículo para el Bullettino dell'Instituto di Corrispondenza Archeologica en Roma con las colecciones de esculturas, bronces y cerámicas greco-romanas (Hübner, 1862/2008: 1), pero su importancia le llevaron a publicar una monografía independiente, Die Antiken Bildwerke in Madrid Las colecciones de arte antiguo en Madrid(1862a), en la cual contó con el apoyo de Jacobo Zóbel de Sangróniz.

Otra línea de trabajo fueron las inscripciones altomedievales, del que publicó Inscriptiones Hispaniae Christianae (1871) y poco antes de morir un suplemento anexo en 1900. También publicó el Corpus de Inscriptiones Latinae del Reino Unido (1873), que el valió el grado de Doctor Honoris causa por la Universidad de Oxford.

Es interesante que antes que a Obermaier en 1922, ya se le ofreció una cátedra extraordinaria a un investigador de reconocida solvencia como era Hübner, según indica Saavedra (1901: 413, 415), "se le ofreció una cátedra de Arqueología que él hubo de rehusar", siendo una lástima no poder precisar la fecha. Hübner tenía una gran capacidad docente, que reflejó en sus Grundriss o programas sobre Filología Clásica, Historia de la Literatura Romana, Gramática Latina y Sintaxis griega que publicó entre (Hübner, 1876, 1878, 1880 y 1883).

En su trabajo sobre la arqueología española, que tuvo un accésit del Premio Martorell en 1887, resultado de sus dos largas estancias entre 1860-61 y 1885-86, indicó los defectos que encontraba en los investigadores contemporáneos españoles, "la falta de instrucción preparatoria para disquisiciones críticas e históricas, la carencia de conocimien- tos profundos del latín, siendo en extremo raros los del griego, y de los diversos ramos de la anticuaria, como la historia de las naciones y del arte del mundo antiguo, así como de su mitología, unido todo ello a la natural inexperiencia en el manejo indispensable de los autores clásicos y textos epigráficos, sean las causas principales, que determinen que en libros aún muy recientes (...) se descubran tantos y tan graves defectos, que ni la retórica más brillante, ni el patriotismo (...) pueden lograr el ocultarlos" (Hübner, 1888: vi-vii).

Por otra parte, su espíritu constructivo se aprecia en muchos detalles. Cuando estudió en Madrid varias colecciones separadas escribió en abril de 1861 al director del Museo del Prado, Federico de Madrazo, rogándole que uniese a la colección real de esculturas clásicas en el Museo del Prado, que contaba con 20 retratos, otros 16 procedentes de la colección de José Nicolás de Azara que estaban en Aranjuez, y se lo razonaba así, "estos dieciséis, unidos en el mismo Museo con los otros, formasen una serie de retratos, que en número y en valor no tendría igual en todos los Museos de Europa, con la excepción de los Museos Capitolino y Vaticano de Roma”. En pocos meses, los retratos se trasladaron al museo según su sugerencia (Tormo, 1947: 500-502).

Está por estudiarse adecuadamente el porcentaje de inscripciones inéditas que Hübner (1869 y 1892) recogió en sus viajes y cuantas inspeccionó directamente en trabajo de campo de las más de 5.000 publicadas en el CIL II y las más de 1.200 que añadió en el suplemento hasta totalizar 6350 , contrastándolas con las previamente recogidas en la Real Academia de la Historia, valorando en éstas también sus mejores lecturas y las que le remitieron sus corresponsales, gracias muchas veces a la mediación de Fernández-Guerra con sus amistades. Autores como Candido María Trigueros habían recopilado más de 600 fichas epigráficas para su proyecto de Inscripciones geográficas antiguas de España que depositó en la Real Academia de la Historia (Mora, 1988: 345), pero fue acusado de falsario por Hübner (1862b).

\section{LAS CLASES MEDIAS DE LA BURGUESÍA ASU- MEN LOS ESTUDIOS ARQUEOLÓGICOS POR AUSENCIA DE ESPECIALISTAS: EL NACIMIEN- TO DE LAS SOCIEdAdeS ArQUeOlógICAS}

En la primera etapa del siglo XIX que va entre 1830 y 1868 , se observa con claridad la ausencia de personas especializadas, lo que les impedirá competir en la investigación cuando los primeros científicos bien formados que llegaran a España a partir de 1860, como el caso de Hübner.

Entre los investigadores más relevantes de este momento que detentaron plazas en la universidad, 
en la Escuela Superior de Diplomática o el Gabinete de la Biblioteca Nacional, su formación universitaria es desigual y nada especializada, Bellas Artes en Amador de los Ríos o Derecho en Delgado, los dos con serios problemas para acabar sus carreras. Derecho estudió Góngora, de Assas, de la Rada, Riaño y Moreno Nieto, aunque éste optó por la lengua que dominaba, el árabe. Sólo de Magisterio en Castellanos de Losada. La excepción fue Gayangos, formado en París porque su madre se exilió. Ni siquiera existió un catedrático en Historia Universal o Historia de España.

Este hecho permitió que la burguesía fuera progresivamente asumiendo los estudios arqueológicos por insuficientes especialistas en las universidades, Escuela Superior de Diplomática y Real Academia de la Historia.

Entre ellos nos encontramos con ingenieros de minas (Casiano del Prado, Schulz), ingenieros de caminos (Saavedra), ingenieros militares (Jaúdenes), arquitectos (Mitjana, Demetrio de los Ríos, Velázquez Bosco), bellas artes (de la Cortina, Ibarra), farmacéuticos (Sepúlveda), médicos (Maraver), comerciantes (Hernández Sanahuja), banca (Rodríguez de Berlanga), jueces (Viú) o miembros del Gobierno Civil (de la Cortina, Albo). En algún caso, como Saavedra, gracias a la excavación de Numancia, fue elegido primero Correspondiente y luego Numerario de la Real Academia de la Historia.

Entre las sociedades arqueológicas españolas, aparte de la Academia Española de Arqueología, con sus 33 sociedades asociadas en 1844, destaca por su antigüedad la Academia Mallorquina de Literatura, Arqueología y Bellas Artes de Palma de Mallorca, creada el 9 de diciembre de 1837 por Ramón Fábregues como presidente, Antonio Furió y Sastre de secretario o Joaquín María Bover de Roselló. Éste último fue después nombrado Correspondiente de la Real Academia de la Historia, Inspector de Antiguiedades en Mallorca desde 1840 y en 1856 cronista de Mallorca (Jiménez Díez y Mederos, 2001: 14, 33, 37).

En Tarragona se fundó el 31 de septiembre de 1844 la Sociedad Arqueológica Tarraconense, Real desde 1914, por cinco coleccionistas, Juan Francisco Albiñana de Borrás, Joaquín Benet, Bartolomé Rivas, J. Soler y José María Torres, ante el temor que la Comisión Provincial de Monumentos de Tarragona, incautase sus colecciones particulares, que ya había hecho el 24 de agosto con la colección y Museo de Antiguiedades del Pallol abierto al público en 1836, propiedad de Vicente Roig y Basora, profesor de Bellas Artes, fallecido en 1837. Parte del estímulo había venido del Ministerio de Gobernación, el cual en una Real Orden de 14 de junio de 1835 invitaba a "los parti- culares a contribuir al establecimiento de un museo de antigüedades y conservar las que existen". La sociedad, el mismo día de su fundación, creó el Museo particular de Antigüedades, Historia Natural y Pinturas de Tarragona, que sirvió de sede social. Esta sociedad les sirvió a dos de sus fundadores, Albiñana y Torres, para acceder en 1845 como vocales en la Comisión Provincial de Monumentos (Remesal, Aguilera y Pons, 2000: 35, 56; Sada y Masso, 1997: 150).

Conocemos también una Sociedad de Antigüedades de Antequera en Málaga, formada por Julián Díaz Roldán y 9 miembros más, que solicitaron realizar excavaciones en Andalucía al Ministerio de Fomento en octubre de 1856 (Maier et alii, 2000: 24).

En Portugal cabe destacar la Sociedade Arqueológica Lusitana, fundada en Setúbal en 1850, que realizó excavaciones en las factorías romanas de salazones de Tróia, mientras que en Lisboa se fundó la Associaçao dos Arqueólogos Portugueses en 1863.

\section{Principales excavaciones aroueológi- CAS ENTRE 1830-67}

Un primer intento para controlar los descubrimientos arqueológicos fue la creación de la figura del Inspector de Antigüedades, nombrado por el Gobierno a propuesta de la Real Academia de la Historia. Andalucía fue el ámbito de actuación del primer nombramiento desde 1838-46, a cargo de Manuel de la Corte y Ruano, aunque por su residencia en Cabra (Córdoba) se centró principalmente en la provincia de Córdoba. En 1840 se nombraron dos inspectores para Mallorca, Joaquín María Bover de Roselló y Juan Muntaner García. Una nueva serie de nombramientos se realizaron en la década de los 50, con Buenaventura Hernández Sanahuja en 1853 para Cataluña y Valencia, aunque su control se centró en Tarragona, por lo que, desde 1857, Esteban Paluzie fue nombrado para Aragón y Valencia, más las provincias catalanas, con excepción de Tarragona (Maier, 2003b: 37 y 2008: 22-23).

No es casualidad que los dos mejores arqueólogos de este periodo, si nos atenemos a la calidad de la documentación gráfica, fueran arquitectos como Eduardo Saavedra y Demetrio de los Ríos, que en el caso de Saavedra se sumaba a su formación de Ingeniero de Caminos. Lamentablemente, en ambos casos no llegaron a publicar una memoria adecuada de sus investigaciones, aunque sí la redactó Demetrio de los Ríos.

Los estudios paleolíticos arrancan con el ingeniero de minas Casiano del Prado, quien inició en 1849 el Mapa Geológico de Madrid, la cual sirvió 
de modelo para el resto de España. Realizando esta labor, localizó en 1850 fragmentos de molar de Elephas en el Tejar de las Ánimas, Ermita de San Isidro, que presentó años después, Restos de un mastodonte en las cercanías de Madrid (1858).

Nacido el 13 de agosto de 1797 en Santiago de Compostela, falleciendo en Madrid el 4 de julio de 1866. Hijo del arquitecto municipal de La Coruña, Melchor del Prado y Mariño, aficionado a la arqueología, pues fue el dibujante de los viajes de José Cornide, inició sus estudios en la Universidad de Santiago de Compostela, pero fue encarcelado entre finales de 1817 e inicios de 1819 por sus ideas liberales. Ya por entonces le interesaba la arqueología porque envió a la Real Academia de la Historia en 1816 un hacha de talón y dos anillas de bronce de las proximidades de Santiago de Compostela. Se incorporó a la milicia durante el Trienio Liberal alcanzando el grado de Subteniente, teniendo que mantenerse escondido varios años con la restauración de Fernando VII. Retomó sus estudios, ahora en la Universidad de Madrid, en el curso 1828-29, en Química docimástica para analizar los minerales y a los 22 años consiguió una beca como alumno pensionado de Minas el 29 de octubre de 1829, hasta finalizar sus estudios el 22 de agosto de 1834, cuando fue nombrado Ingeniero de Minas de tercera clase, siendo destinado como Inspector de Minas de Aragón y Cataluña en 1835 (Pérez de Barradas, 1928: 1; Maier y Martínez Peñarroya, 2001: 116-117; González Ruibal, 2000), iniciando contactos con la arqueología tarraconense (del Prado, 1837).

Separado de su destino en 1840, con 43 años, después del levantamiento del general Espartero contra la Regente la Reina María Cristina según Pérez de Barradas (1928: 2), aunque Maier y Martínez Peñarroya (2001: 120) sugieren que lo apoyó, fue readmitido y destinado el 4 de abril de 1841 como Director de las Minas de Almadén. Después del pronunciamiento de Narváez, Prim y Serrano y la mayoría de edad de Isabel II, sufrió alejamiento del puesto de trabajo de Almadén, siendo enviado primero a la Inspección de Minas en Sierra Almagrera (Almería) y Murcia en noviembre de 1843 , y a inicios de 1844 fue destinado a Asturias y Galicia, lo que le llevó a pedir exedencia de su puesto en agosto de 1844, para trabajar en la búsqueda de minas de carbón para la Sociedad Palentino-Leonesa de Santiago Cordero, quien montó en 1847 hornos de coke en Sabero (León). Solicitada su reincorporación febrero de 1848, fue nombrado Director de las Minas de Riotinto (Huelva) el 23 de junio de 1848, siendo pronto trasladado en octubre de 1849 a Madrid como vocal de la sección de Geología y Paleontología de la Comisión de la Carta
Geológica de Madrid y la General del Reino, después denominada Comisión del Mapa Geológico de España, que había sido creada el 11 de junio de 1849 por Francisco de Luxán (Pérez de Barradas, 1928: 2; Maier y Martínez Peñarroya, 2001: 120121; Puche, 2004: 81).

Desde 1850 comenzó a colaborar con Edouard de Vernouil, que realizaba el estudio de los restos fósiles, mientras Casiano del Prado estudiaba la geología de Sabero y las montañas de León, por la presencia de minas de carbón (del Prado y Verneuil, 1850), que luego ampliaron a la Cordillera Cantábrica, encargándose también Verneuil de los restos fósiles junto con Joachim Barrande (del Prado, Verneuil y Barrande, 1860).

Ya por entonces, el interés por los útiles paleolíticos empieza a ser más envidente. Por una parte, Casiano del Prado trajo de París en 1860 un "hacha de silex" de Amiens (Somme, Picardía, Francia) (Puche, 2004: 83), presumiblemente de Abbeville o Saint Acheul, y lo depositó en la Escuela de Minas y la Revista Minera tradujo en 1861 un artículo de Boucher de Perthes, Sobre los sílex encontrados en el diluvium del departamento de la Somme.

Su aportación más importante fue el descubrimiento de útiles de sílex en San Isidro en 1862, cuando Casiano del Prado ya tenía 65 años. El estímulo vino de Edouard de Vernouil, antiguo presidente de la Sociedad Geológica de Francia y autor entre 1849-62 de la Carta geológica de España y Portugal (Verneuil y Colomb, 1864) y Louis Lartet, con quienes localizó un útil lítico en San Isidro durante 1862 (Verneuil y Lartet, 1863). Su participación en el hallazgo hizo que fuese nombrado en noviembre de 1862 socio de la Société Géologique de France. El propio Casiano del Prado (1866: 188) reconoció que los había visto ya desde hacia 12 años sin tener conocimientos para valorarlos, "En 1850 he visto en el diluvium de San Isidro estos sílex, de que yo no tenía la menor idea, y lo que más es, casi siempre en la división del guijo y debajo de las capas en que se hallaron los huesos de Elefante, pues rara vez se ven en a un nivel superior. Sin embargo, no dejaron de fijar mi atención al ver que ninguno se hallaba rodado (...) pues entre las rocas de la tierra no hay pedernal alguno".

Entre los yacimientos neolíticos, merecen reseñarse la excavación de la Cueva Lóbrega en la Sierra de Cameros (Torrecilla de Cameros, La Rioja), en agosto de 1865, por Edouard y Louis Lartet, siguiendo las indicaciones de Zubia sobre cuevas de la Sierra de Cameros, visitándolas acompañados por el farmaceutico Pedro Blanco (Lartet, 1866). Después de su publicación, la Sociedad 
Antropológica de Madrid escribió a Ildefonso Zubia e Icazuriaga, como socio de la misma, para que realizase excavaciones en Cueva Lóbrega, lo que hizo también acompañado de Pedro Blanco en agosto de 1866 (Ollero, 1990: 207-208). Ildefonso Zubia nació en Logroño el 24 de enero de 1819. Empezó sus estudios en el Seminario de la ciudad, para continuarlos en Madrid en el Colegio de Farmacia de San Fernando donde obtuvo el Bachiller en Filosofía en 1839. Realizó los cuatros cursos de la Facultad de Farmacia de la Universidad Central de Madrid entre 1840-43, colaborando en su último curso como Ayudante de la Cátedra de Química. Obtuvo el grado de Doctor el 5 de octubre de 1843, siendo ya nombrado desde el 2 de octubre Catedrático provisional de Historia Natural en el Instituto de Segunda Enseñanza de Logroño, plaza que consolidó al opositar en 1844 y por nueva oposición ganó la Cátedra de Historia Natural de la Universidad de Oviedo el 22 de junio de 1847. Sin embargo, el clima no le favoreció a su delicada salud y solicitó su reincorporación a su Cátedra de Instituto en Logroño, que le fue concedida el 16 de noviembre de 1847, a la cual acumuló el 19 de marzo de 1856, la Cátedra de Física y Química, y donde ya permaneció hasta fallecer el 3 de junio de 1891 (Ollero, 1990: 193-196).

Otro estudio importante fue el descubrimiento en marzo de 1867 de la Cueva de los Murciélagos (Albuñol, Granada), con la primera metalurgia del oro, durante el Neolítico Final II, publicado por el Catedrático de Historia Universal de la Universidad de Granada, Manuel de Góngora y Martínez, en Antigüedades Prehistóricas de Andalucía (1868), libro centrado en Granada y Jaén, pues inicialmente pensaba titularse Descubrimientos acerca de las razas que poblaron algunas de las comarcas del antiguo reino granadino (Góngora, 1868: 6). Otros datos interesantes son la publicación de varios dólmenes calcolíticos, Alcalá la Real (Jaén) o Dílar, Huélago, Guadix y Gorafe (Granada). Ajuares funerarios argáricos en Caniles y Alcudia de Guadix (Granada). Y en particular, la presencia de cuevas con arte esquemático en la Cueva de los Letreros (Vélez Blanco, Almería) y en Peña Escrita y La Batanera (Fuencaliente, Ciudad Real), éstas últimas ya descubiertas por el cura de Montoro, Fernando José López de Cárdenas en el siglo XVIII, a cuyo conocimiento accedió a través de Fernández-Guerra, quien tenía su documentación.

Para el Calcolítico destaca la localización en 1842 y el estudio por el arquitecto Rafael Mitjana de la Cueva de Menga (Antequera, Málaga), interpretado como templo celta druida (Mitjana, 1847), Memoria sobre el templo druida hallado en las cercanías de la ciudad de Antequera. Por su parte, el ingeniero Guillermo Schulz, director de la Escuela de Minas (1854-57), localizó la mina calcolítica de cobre de El Milagro (Onis, Asturias), publicando la nota, Mina antiquísima en Asturias (1854), durante la elaboración del mapa geológico de Asturias (1858).

Entre los poblados del Bronce, cabe citar a José Pla y Costa, quien exploró en 1845-46 el poblado del Castellet del Porquet (La Ollería, Valencia), creyendo que era un dolmen, hasta que fue reexcavado en 1937 por Ballester (1937).

De la Protohistoria, cabe citar algunas excavaciones realizadas por Francisco Martorell y Peña, futuro creador del premio Martorell, en la isla de Mallorca en 1858, entre ellas en San Hilario de Sacalm (Cebriá, Muro y Ríu, 1991: 81), quien plantearía un estudio de los monumentos megalíticos en sus Apuntes Arqueológicos (1879).

De la época orientalizante, el descubrimiento de un oinocoe y un thymiaterion de bronce en Las Herencias (Toledo) en 1860, de los que envió un buen dibujo Luis Jiménez de la Llave, Correspondiente en Talavera de la Reina (Fernández-Miranda y Pereira, 1992; Maier, 1999c: 94-95, 94 fig. 21). Otro hallazgo importante en 1860 fueron los bronces orientalizantes de un carro en Máquiz (Mengibar) (de los Ríos, 1877b; Maier, 2008: 260)

Sobre la presencia griega y romana destacó las excavaciones en Ampurias, primero en 1834 por la Junta de Antigüedades de La Escala que redactaron una memoria sobre los hallazgos en la Real Sociedad de Amigos del País, continuadas por el Jefe Político de Gerona en 1841, que recibió informe desfavorable de la Real Academia de la Historia (Maier, 2008: 35-36). En todo caso, las excavaciones se reanudaron entre 1846-48, financiadas por la Diputación Provincial, dirigidas por Gabriel de Molina, administrador de la Aduana de La Escala, como delegado de la Comisión Provincial de Monumentos de Gerona (Almagro Basch, 1951: 173; Remesal, Aguilera y Pons, 2000), que continuaron aparentemente en 1851 (Ganau, 1997: 57), y después puntualmente por el secretario de la Comisión Provincial de Monumentos de Gerona, el abogado y coleccionista, Celestino Pujol y Camps, quien realizó nuevos "reconocimientos" en dos estructuras romanas descubiertas en las excavaciones de 1848 (Buscató y Pons, 2001: 167-169).

En el ámbito celtibérico, coincidiendo con la fase final de las actuaciones en Numancia, el farmacéutico Fernando Sepúlveda y Lucio realizó excavaciones en 1866 en un posible sector de necrópolis del Llano de San Pedro (Valderrebollo, Guadalajara), aunque la descripción no es clara, 
continuadas en 1877, con la colaboración del coleccionista de monedas, Constantino Domingo Bazán, excavando en un sector del castro, donde localizó estructuras de muro, redactando una interesante memoria en 1879 (Sepúlveda, 1879/1995; Abascal, 1995; Maier, 1999c: 70-72, 72 fig. 15-16).

En la etapa protohistórica, el aspecto más relevante son los primeros datos sobre la cultura ibérica. Si ya se conocía monedas con este alfabeto, dos importantes nuevos descubrimientos ampliaron su distribución, al aparecer plomos con escritura ibérica del Pujol del Gasset (Grau de Castellón) en 1851 y de Gádor (Almería) en 1862 (Maier, 2008: 265). La primera necrópolis ibérica fue excavada por el médico y periodista Luis Maraver y Alfaro en Almedinilla (Córdoba) en 1867, para dotar de piezas arqueológicas el Museo de Córdoba, fundado en 1868 , pero inicialmente fue considerada romana.

Dentro del grupo de las ciudades romanas, las actuaciones más importantes se desarrollaron en las ciudades de Itálica, Tarraco y Emerita Augusta. La primera fue Mérida, donde se hicieron excavaciones en 1836, dirigidas por Mariano Albo, Gobernador Militar de Mérida, centradas en la Casa del Mitreo, descubriéndose un mosaico romano. En 1838, Ivo de la Cortina colaboró en la clasificación de los materiales recuperados en el Convento de Santa Clara, para el Museo Arqueológico de Mérida creado por Real Orden del 26 de marzo de 1838, siguiendo órdenes del Jefe Político, actual Gobernador Civil. No pudieron continuarse las actuaciones en 1840 por el Jefe Político, porque la Real Academia de la Historia informó desfavorablemente por el empleo de presos en la nueva excavación (Maier, 2008: 34; Luzón, 1999: 74).

En Itálica, fue Ivo de la Cortina y Roperto, nacido en Vilanova i la Geltrú o Sitges en 1805, pintor e ilustrador gráfico, oficial del Gobierno Civil y miembro de la Real Academia Sevillana de Buenas Letras, a instancias del Jefe Político, debido al descubrimiento de esculturas por la ampliación de la carretera de Extremadura, entre Sevilla y Badajoz, a su paso por Santiponce. Inició excavaciones desde enero de 1839 hasta finales de 1840, colaborando Amador y Demetrio de los Ríos, utilizando presos, trabajos que publicó parcialmente en fascículos para una monografía, Antigüedades de Italica (de la Cortina, 1840), que quedó inconclusa con sólo 54 páginas (de la Cortina, 1845: 30; Luzón, 1999: 74; Canto y de Gregorio, 2001: 157159; Maier, 2008: 34-35). Para estimular a los presos y evitar robos se pagaban 20 reales por una estatua, 3 reales por un camafeo o 20 maravedises por una lámpara romana (Luzón, 1999: 75).
Las actuaciones fueron continuadas por Amador de los Ríos desde 1841 hasta al menos 1843, que dejó inédito su Itálica: historia de esta ciudad famosa desde su fundación hasta nuestros días, con todos sus descubrimientos (1845) y después fueron retomadas desde 1860 hasta 1868 por su hermano Demetrio de los Ríos, financiadas por la Diputación Provincial de Sevilla, quien también dejo otra obra inédita, Itálica. Historia y descripción artística de esta infortunada ciudad (1879) y un levantamiento topográfico en 1861.

Ivo de la Cortina regresó a Cataluña como Secretario del Jefe Político de Tarragona, siendo nombrado también Secretario de la Comisión Provincial de Monumentos y responsable de las excavaciones en la Cantera del Puerto de Tarragona hasta marzo de 1846 (Remesal, Aguilera y Pons, 2000: 37-42), piedra utilizada en la ampliación del puerto, obras que se intensificaron desde 1834 (Saavedra, 1894: 338). En estas excavaciones se localizó, el 2 de febrero de 1845, el Mosaico de la Medusa en la Cantera del Puerto, que tuvo que trasladarse al Museo en 1856, ante el avance de la cantera (Remesal, Aguilera y Pons, 2000: 90).

Tarraco fue una de las ciudades con investigaciones más activas gracias a la labor de Buenaventura Hernández y Sanahuja. Nacido en Tarragona el 30 de mayo de 1810, había estudiado en el Seminario Conciliar de Tarragona, latín y humanidades, dedicándose posteriormente al comercio minorista, regentando una tienda, y sosteniendo una familia de 10 miembros (Saavedra, 1894: 338-339, 364). Aficionado a la numismática, entró en la Sociedad Arqueológica Tarraconense en marzo de 1845, un año después de su fundación y en la Academia Española de Arqueología en 1848. Adquirió renombre con motivo de la gradual aparición de "restos egipcios" durante la excavación de la cantera para el Puerto de Tarragona. Su Descripción razonada del sepulcro Egipcio encontrado en Tarragona en marzo de 1850, que remitió a la Real Academia de la Historia en mayo de 1851, propició que se ejerciera un control de las excavaciones y los materiales recuperados, los cuales desde junio de 1852 fueron depositados en el Museo Arqueológico de Tarragona, evitando el expolio que venía sucediendo, concediendo el Ministerio de Gobernación ese mes autorización y financiación de 8.000 reales para las excavaciones. Un nuevo paso para incrementar el control fue su nombramiento como Inspector de Antigüedades de Cataluña y Valencia el 15 de diciembre de 1853, aunque se centró en Tarragona, destacando su trabajo Resumen histórico-crítico de la ciudad de Tarragona desde su fundación hasta época romana, con una explicación de los fragmentos del sepulcro egipcio descubierto en 9 de marzo de 
1850 (1855), consolidando su situación cuando fue nombrado Director-conservador del Museo Arqueológico de Tarragona por la Real Academia de Bellas Artes de San Fernando el 6 de marzo de 1865 (Remesal, Aguilera y Pons, 2000: 37-42, 199206), al reorganizarse las Comisiones Provinciales de Monumentos. El sepulcro egipcio pronto fue considerado una falsificación por Hübner (1862/2008: 318-319).

Entre ciudades de menor tamaño cabe mencionar la reanudación de las excavaciones en Cártama (Málaga), después de los trabajos del Marqués de Valdeflores. Las excavaciones, dirigidas por dos ingenieros militares, José María Jaúdenes y el Capitán retirado Joaquín Sánchez Navarro, se desarrollaron entre diciembre de 1833 y marzo de 1834, bajo la supervisión del Gobernador Militar y Jefe Político de Málaga, General Antonio María Martínez, utilizando como trabajadores a presidiarios (Maier, 2008: 33-34).

En 1854, se autorizaron excavaciones a Rafael Atienza y Huertos, Marqués de Salvatierra, en Acinipo (Ronda, Málaga), por parte de la Real Academia de la Historia, el 23 de junio (Maier, 2008: 63, 207), pues era académico e incluso participó en esta sesión. En Ronda la Vieja hizo excavaciones José Oliver y Hurtado que en su Viaje arqueológico de 1857 creyó identificar con Munda, Monda-Ronda, donde fue la victoria de Julio César contra Pompeyo.

Para Extremadura romana, y en particular Cáceres, destaca el trabajo del juez de primera instancia, José de Viú y Cáceres, autor de la Colección de inscripciones y antigüedades de Extremadura (Viú, 1846 y 1852; Celestino y Celestino, 2000: 13, 69).

Es posible que también se iniciaran excavaciones en Clunia (Peñalba de Castro, Burgos) en 1841. Se habían solicitado desde 1832 por Isidro Ontoria, actuación aprobada años después durante la Regencia de Espartero, desde octubre de 1840 (Maier, 2008: 36).

En 1867, la excavación de Lancia (León) por el arquitecto Ricardo Velázquez Bosco, miembro de la Comisión Provincial de Monumentos de León, permitió localizar un mosaico romano, para recuperar materiales arqueológicos ante la apertura del Museo de León en 1869, con apoyo económico de la Diputación Provincial y el Ayuntamiento, paralizándose la excavación con la revolución del 68 (Madrazo, 1882: 169; González Alonso, 1997: 201).

Sobre la romanización en el País Valenciano, la actuación más interesante es la excavación de la Alcudia de Elche por Aureliano Ibarra y Manzoni, entre 1856-63, quien publicó años después Illici, su situación y antigüedades (1879). Nacido en
Alicante en 1834, se formó en grabado en la Academia de Bellas Artes de Barcelona entre 1850-53, estudios que no finalizó (Papí Rodes, 2009: 341). En sus excavaciones trató de demostración que Ilici se encontraba en la Alcudia y no en Alicante, destacando el hallazgo de algunos mosaicos romanos como el de Galatea, localizado en 1861 (Ibarra, 1879: 181, lám. 14) y a documentar la presencia del Portus Ilicitanus.

En el País Vasco, dentro del contexto de las guerras carlistas y la defensa de los fueros, un diputado carlista, Ramón Ortiz de Zárate, publicó Jamás los romanos conquistaron completamente a los Vascongados y nunca estos belicosos pueblos formaron parte integrante del Imperio de los Césares (1848) (Ortiz de Urbina y Pérez Olmedo, 1991: 113-114). Sin embargo, las excavaciones de Florencio Janer y Graells, Gobernador Civil y Presidente de la Comisión Provincial de Monumentos de Álava, que excavó de Iruña (Iruña de Coca, Álava) en 1866 y 1868 (Ortiz de Urbina, 1999: 17-19), las cuales no se volvieron a retomar hasta 1901, pusieron en evidencia la presencia romana en el País Vasco, lo que se refleja ya en la tesis de López Mendizábal (1899).

Para el medievo islámico, destaca el hallazgo de una necrópolis en Atarfe, Sierra Elvira (Granada) (Marqués de Gerona, 1843), el libro sobre las Inscripciones árabes de Granada (1859) redactado por Emilio Lafuente Alcántara y las excavaciones de la Comisión Provincial de Monumentos en la Alcazaba de Badajoz, después del hallazgo de unas lápidas islámicas (Celestino y Celestino, 2000: 13).

\section{CONCLUSIONES ENTRE 1830-67}

\section{INSTITUCIONES EDUCATIVAS: UNIVER- SIDADES Y ESCUELA SUPERIOR DE Diplomática}

El Plan Caballero de 1807 creó las facultades de Filosofía, pero sólo se cursaban 3 años y otorgaban un grado de Bachiller en Artes, que permitía el acceso a las facultades de Leyes, Cánones, Medicina y Teología. No fue hasta la Ley de Instrucción Pública (1857) de Claudio Moyano, cuando Filosofía y Letras pasó a ser estudios superiores. Se dividían en 3 años para el grado de Bachiller, con las asignaturas de Historia General e Historia de España que se impartían en el $3^{\circ}$ curso. Dos años de Licenciatura, impartiéndose en $4^{\circ}$ y $5^{\circ}$ curso Lengua Hebrea y en $5^{\circ}$ curso Lengua Árabe. El curso de doctorado o $6^{\circ}$ año sólo incluía dos asignaturas de Literatura, lenguas neolatinas y teutónicas, que fue ampliándose. Esto implicaba que no había ninguna asignatura de especialidad, no ya de Arqueología, sino ni siquiera de Historia, para 
un Licenciado o un Doctor, problema que se arrastró hasta el cambio de planes de estudio en junio de 1900.

Con la creación de la Escuela Superior de Diplomática el 7 de octubre de 1856, la situación no mejoró significativamente. El plan de estudios estaba centrado en Paleografía y sólo contemplaba una asignatura de Historia en el tercer curso, Historia de España en los siglos medios, o Edad Media, con 3 horas semanales, y otra de Arqueología y Numismática, de la que se impartían 3 horas semanales en segundo curso. El proceso de selección de profesor de Arqueología $y$ Numismática se dirimió en dos jóvenes sin ningún bagaje científico significativo en dichas materias hasta el momento de acceder a plaza, Florencio Janer y Graells, de 25 años, candidato del Director, Modesto Lafuente, y Juan de Dios de la Rada y Delgado, de 27 años, candidato del Ministro de Gracia y Justicia, Joaquín Aguirre, y como solía pasar, ganó el ministro, desarrollando de la Rada una notable carrera a partir de fines de los años sesenta cuando fue madurando como investigador.

El nuevo director en propiedad desde 1860 hasta fines de 1865 fue el numísmata Antonio Delgado, apoyado por la Unión Liberal de Leopoldo O'Donnell. Durante su mandato, en julio de 1863, hubo un aumento la carga docente de la arqueología de 3 a 9 horas semanales, Numismática antigua y de la Edad Media, y en especial de España, impartida por de la Rada, Epigrafía y Geografía Antiguas y de la Edad Media por Delgado e Historia de las Bellas Artes en los tiempos antiguos, Edad Media y Renacimiento, con la arqueología monumental, impartida por Juan Francisco Riaño y Montero. La causa fue el intento del nuevo Ministro de Fomento, Manuel Merino, de compensar a Riaño con una Cátedra de Historia de las Bellas Artes que le habían quitado en 1861 en la Escuela Superior de Pintura, Escultura y Grabado, lo que fue aprovechado por Delgado para crear una asignatura para impartir él.

\section{INSTITUCIONES OFICIALES: REAL ACAdemia de la Historia, MUSEOS Y Comisiones Provinciales de Monumentos Históricos y ARTísticos}

La labor de la Real Academia de la Historia dependió mucho de la figura del Anticuario, cuando su elección fue la persona correcta, como sucedió con Delgado entre 1848-66, que además ocupó otro cargo importante, la dirección de la Escuela Superior de Diplomática, la actividad fue mejor. Cuando la elección no fue la más afortunada, como sucedió con el granadino Juan Bautista Barthe entre 1836-48, que carecía de estudios, la acción de la Academia se resintió notablemente. Con la renuncia de Delgado, entró el literato Aureliano Fernández-Guerra, primero como Anticuario en funciones en 1866, después Anticuario interino desde 3 de mayo de 1867 y finalmente Anticuario por elección el 6 de diciembre de 1867, frente a la candidatura de Pascual de Gayangos, que tenía más antigüedad y méritos. La persona más adecuada para el puesto de Anticuario, Amador de los Ríos, que presidía la Comisión de Antigüedades en la Real Academia de la Historia, y quien dos meses después, en febrero de 1868, fue nombrado Director del Museo Arqueológico Nacional, no se presentó, pues tenía más antigüedad también que Fernández-Guerra, pero menos que Gayangos, y es posible que respetase ese criterio, o ya sabría que Fernández-Guerra tenía los apoyos suficientes.

La creación de un Museo de Antigüedades ya fue solicitada a Fernando VII por dos Supernumerarios de la Real Academia de la Historia desde inicios de 1830, pero se indicó que el museo debía esperar a "cuando haya proporción y medios para verificarlo", al igual que las enseñanzas pues "el estado actual del R[ea]l. Tesoro no permite la dotación de cátedras para el estudio de las antiguiedades". En cambio fue ganando importancia el Gabinete de Antigüedades y del Museo de Medallas de la Biblioteca Real, Biblioteca Nacional desde 1826, cuyo conservador fue Basilio Castellanos de Losada, cuyas colecciones fueron la base del Museo Arqueológico Nacional, creado nominalmente por Real Orden el 20 de marzo de 1867, aunque no se inauguró hasta el 9 de julio de 1871

Respecto a los Museos Provinciales, ya antes del proceso de desamortización de Juan Mendizábal de febrero de 1836, se empezaron a crear museos específicamente arqueológicos generalmente asociados a importantes yacimientos. Así surgió el Museo Arqueológico de Sevilla (1835) para conservar las colecciones de Italica y se solicitó desde 1834 el Museo Arqueológico de Tarragona (1836), por los restos de Tarraco, del que Buenaventura Hernández y Sanahuja fue su director-conservador desde 1865. También en Barcelona, con el inicio de los primeros derribos de conventos, la Real Academia de Buenas Letras creó un Museo de Antigüedades en 1835.

La desamortización de Juan Mendizábal, aprobada el 19 de febrero de 1836, afectó a los bienes de las órdenes religiosas monásticas o clero regular, y para los recuperar los fondos bibliográficos y artísticos se crearon el 27 de mayo de 1837 las Juntas Científico-Artísticas en cada capital de pro- 
vincia, presididas por el Jefe Político, actual Gobernador Civil, y compuesta por 5 personas elegidas por él. En esta fase cabe mencionar la creación del Museo Arqueológico de Mérida (1838), después del inicio de las excavaciones en Mérida en 1836.

Fueron reorganizadas como Comisiones Provinciales de Monumentos Históricos y Artísticos por Real Orden el 13 de junio de 1844. Las comisiones eran dependientes de la Real Academia de Bellas Artes de San Fernando, pero fueron financiadas por las diputaciones provinciales. El principal objetivo en 1844 fue la creación de una Comisión Central, que coordinara las Comisiones Provinciales, presidida por el Ministro de Gobernación, un vicepresidente y un secretario, el único con sueldo, el cual llevaba el peso de la Comisión Central, que recayó en Amador de los Ríos, más 5 vocales. La organización de las Comisiones Provinciales fue bastante parecida, siguió siendo presidida por el Jefe Político y compuesta por 5 personas, 3 nombrados por el Jefe Político y 2 por la Diputación Provincial.

Con el cambio del Reglamento de las Comisiones Provinciales en noviembre de 1865, pasaron a representar a ambas academias en el ámbito provincial, no sólo a la Real Academia de Bellas Artes de San Fernando, sino también a la Real Academia de la Historia que ganó influencia. Las Comisiones eran presididas por el Gobernador Civil de la provincia, la vicepresidencia recaía en el Correspondiente más antiguo de una de las dos academias, la secretaría en el Correspondiente más joven, y tres puestos de vocales en los restantes correspondientes. En el nuevo reglamento otorgaba a sus miembros la dirección de las excavaciones arqueológicas de cada provincia, una vez autorizadas por el Gobernador Civil y en particular por la Real Academia de la Historia, en la que a partir de entonces recayó la inspección de "todas las antiguiedades descubiertas y que se descubrieran en el reino".

Entre los museos creados por las Comisiones Provinciales estuvieron el Museo de Bellas Artes de Córdoba (1844), el Museo de Orense (1845), el Museo Provincial de Antigüedades o Arqueología de Oviedo (1845), el Museo de Gerona (1846), o el Museo Arqueológico de Lérida (1864), que ya venía funcionando como sede de un Museo de Antigüedades desde 1847.

\section{Cllases medias burguesas y la Academia Española de Aroueología}

La burguesía fue progresivamente asumiendo los estudios arqueológicos por insuficientes especialistas en las universidades, Escuela Superior de
Diplomática y Real Academia de la Historia. Entre ellos nos encontramos con ingenieros de minas (Casiano del Prado, Schulz), ingenieros de caminos (Saavedra), ingenieros militares (Jaúdenes), arquitectos (Mitjana, Demetrio de los Ríos, Velázquez Bosco), bellas artes (de la Cortina, Ibarra), farmacéuticos (Sepúlveda), médicos (Maraver), comerciantes (Hernández Sanahuja), banca (Rodríguez de Berlanga), jueces (Viú) o miembros del Gobierno Civil (de la Cortina, Albo).

Por otra parte, la escasa actividad del Anticuario de la Real Academia de la Historia, Juan Bautista Barthe entre 1836-48, facilitó el despegue de una sociedad arqueológica que pronto alcanzó ámbito nacional y ocupó las parcelas arqueológicas que no cubría. Primero Castellanos de Losada creó la Sociedad Numismática Matritense (1837-39), luego Sociedad Arqueológica Matritense y Central de España y sus Colonias (1839-44), después Academia Española de Arqueología (1844-60), Academia Española de Arqueología y Geografía (1860-63) y finalmente Academia Real de Arqueología y Geografía del Príncipe Alfonso (1863-68), al ser elegido el Príncipe Alfonso, futuro Alfonso XII, como su protector, concediéndole por el 3 de julio de 1863 el título de Real.

La ausencia de docencia en arqueología, que no se introdujo hasta la creación de la Escuela Superior de Diplomática en 1856 en el ámbito de la Numismática y de la Arqueología Monumental hasta 1863, favoreció la docencia externa principalmente en el Ateneo Científico y Literario de Madrid. La docencia fue primero impartida por Castellanos de Losada en Arqueología (1837-39), Numismática aplicada a la legislación española (1839-40), Elementos de historia y arqueología universal (1840-41) у Arqueología (1848-49).

Su labor fue continuada por Manuel de Assas y de Ereño, miembro también de la Academia Española de Arqueología, quien dio clases de Historia de la Arquitectura Española (1846-47), Historia de las Bellas Artes (1848-49), Historia Universal de la Arquitectura (1849-52), Lengua y literatura sánscrita (1853-54), Lengua céltica (1856-58) y Arqueología Española (1854-56 y 1858-60).

La Academia Española de Arqueología contaba con 33 sociedades distribuidas en Galicia ( $\mathrm{La}$ Coruña, Santiago de Compostela, Lugo, Orense), Oviedo, Santander, País Vasco (Bilbao, Guipúzcoa), Navarra, Aragón (Huesca, Zaragoza), Cataluña (Gerona, Lérida, Barcelona), CastillaLeón (Valladolid, Burgos, Segovia), Castilla-La Mancha (Toledo, Ciudad Real, Cuenca), Badajoz, País Valenciano (Valencia, Alicante), Mallorca, Murcia, Andalucía (Granada, Jaén, Córdoba, 
Sevilla, Cádiz), Canarias, Cuba y Filipinas. En alguna ciudad como Sevilla se citan hasta 40 miembros en 1866. Por otra parte, si tenemos en cuenta que cada diputación arqueológica necesitaba un mínimo de 5 miembros, eso indica al menos 165 miembros en 1844. En 1864, sabemos que contaba nada menos que con 1.056 miembros repartidos por toda España, Cuba, Filipinas y extranjero.

\section{LEGISLACIÓN Y FINANCIACIÓN DE LAS EXCAVACIONES ARQUEOLÓGICAS}

El intento de venta al British Museum del Disco de Teodosio en 1847, que se consiguió deshacer el trato pagando 27.500 reales de vellón en 1847, y la posterior venta de 8 coronas y 5 cruces de Guarrazar al Museo de Cluny, en febrero de 1858, por 72.000 reales, puso en evidencia la necesidad de regular los hallazgos ocasionales por Ley y las serias dificultades para conseguir fondos con que poderlos adquirir.

Durante el gobierno de Leopoldo O'Donnell, el Director General de Instrucción Pública solicitó el 14 de diciembre de 1859 que la Real Academia de la Historia elaborase un Proyecto de Ley de Excavaciones y Antigüedades. Las peticiones se sucedieron durante 9 años hasta el 26 de octubre de 1868, ya con primer gobierno durante el Sexenio Revolucionario, presidido por el general Francisco Serrano Domínguez, sin que se contestase. Los responsables fueron los dos anticuarios, Antonio Delgado entre 1860-66 y Aureliano FernándezGuerra entre 1867-68, e indirectamente del entonces Presidente del Tribunal Supremo, el letrado y Numerario Pedro Gómez de la Serna.

A pesar de todo, la Real Academia de la Historia fue acaparando competencias, por una parte la inspección de "todas las antigüedades descubiertas y que se descubrieran en el reino" desde noviembre de 1865 . Por otra parte, desde el Bienio Progresista, en 1854, se financió excavaciones promovidas por la Academia como Numancia, que tuvieron regularidad entre 1861-65, recibiendo durante la Unión Liberal anualmente 50.000 reales para excavaciones, de los que 25.000 se destinaron para Numancia. En 1865 se tenían previsto 200.000 reales para la realización de excavaciones en Numancia, Itálica, Mérida, Murviedro [Sagunto], etc.

Finalmente, el Gobierno estableció un Plan General de Excavaciones en 1868, del que se libraron a las respectivas Comisiones Provinciales de Monumentos, 8.000 escudos para excavaciones en Itálica, de los 35.000 escudos previstos, cuadruplicando los 8.000 escudos de 1867; 2.000 escudos para la excavación de La Alcazaba de Granada, donde se creía estaba el foro de la ciudad romana y en Sierra Elvira; 1.000 escudos para la excavación de Augustóbriga en Soria; 600 escudos para la excavación en el Castillo de Montesa e Iglesia de San Félix en Játiva, Valencia; 461 escudos para la excavación en el teatro romano de Mérida; y 400 escudos para las excavaciones destinadas a localizar la batalla de Munda en Córdoba, todas antes del inicio del Sexenio Revolucionario el 30 de septiembre de 1868.

\section{LOS ARQUEÓLOGOS}

El elemento más dramático es la represión de Fernando VII después del Trienio Liberal a los que tenían ideología liberal, que les interrumpió gravemente el proceso de formación académica. Una opción fue exiliarse en el extranjero como sucedió con Castellanos de Losada en Italia entre 1824-26, a la madre de Gayangos en Francia entre 1825-28 o al padre de Amador y Demetrio de los Ríos de 1823-32. La otra fue el exilio interior a zonas rurales para escapar de la prisión que llegaron a conocer Castellanos de Losada entre 1823-24, Casiano del Prado entre 1817-19 o brevemente Delgado en 1823. Esa fue la opción de Delgado y su padre que se fueron de Sevilla a Trigueros (Huelva) entre 1823-33, Amador de los Ríos de Baena a Córdoba entre 1827-32, García Blanco de Madrid a tierras del Marqués de La Gomera entre 1823-27, Casiano del Prado de Santiago de Compostela al campo entre 1823-28, con una enorme pérdida de años de formación en una etapa clave de sus vidas.

En general, los arqueólogos proceden de familias de la mediana burguesía con estudios, hijos de abogados como Delgado, de médicos como García Blanco, de arquitectos como Casiano del Prado, de comerciantes como Hernández Sanahuja, de militares como Gayangos, Rodríguez de Berlanga, Saavedra o Fernández y González, de marinos como Assas o profesores universitarios como García Blanco. Estudios tenía con seguridad el padre de Góngora. Entre las excepciones están Castellanos de Losada, cuya familia optó por ponerlo como paje de un Arzobispo, y mandó al ejército a sus tres hermanos. El padre de Amador y Demetrio de los Ríos había sido carpintero, pero se formó después como escultor y con la propiedad de un molino de pan con su hermano mejoró económicamente, hasta que se lo quemaron los milicianos realistas.

Entre los investigadores más relevantes que detentaron plazas en la universidad, en la Escuela Superior de Diplomática o el Gabinete de la Biblioteca Nacional, su formación universitaria es desigual y nada especializada, Bellas Artes en Amador de los Ríos o Derecho en Delgado, los dos 
con serios problemas para acabar sus carreras, que realmente convalidaron posteriormente. Derecho estudió Góngora, Assas, Rada, Riaño y Moreno Nieto, aunque éste optó por la lengua que dominaba, el árabe. Sólo de Magisterio en Castellanos de Losada. La excepción fue Gayangos, formado en Francia desde 1822, donde continuó porque su madre se exilió y asistió durante 3 años clases de árabe con el orientalista Silvestre de Sacy en la École spéciale des Langues Orientales. Las cátedras en Historia Universal o Historia de España no se crearon hasta el plan Moyano de 1857, ambas para impartirse en tercer curso del Bachiller en Filosofía y Letras, ocupando Góngora en 1860 la de Historia Universal para la Universidad de Granada.

Precisamente por su buena preparación, Gayangos formó después en árabe desde su cátedra en la Universidad Central a Moreno Nieto, Saavedra, de Assas y a Delgado para leer las monedas con epígrafes árabes. García Blanco enseñó hebreo a Amador de los Ríos y de Assas.

Otro aspecto llamativo fue la necesidad de marchar a Madrid de la mayor parte de ellos para desarrollar su actividad profesional. Amador de los Ríos desde Sevilla, García Blanco desde Osuna (Sevilla), Delgado desde Huelva, de la Rada, Riaño y Moreno Nieto desde Granada, Casiano del Prado desde Santiago de Compostela o de Assas de Santander. Se aprecia también la continua pérdida de sus miembros más preparados que sufrieron las dos universidades andaluzas, a veces ante la ausencia de puestos de trabajo, que sí tuvieron Moreno Nieto y Riaño en la Universidad de Granada, proceso que continuó durante la Restauración. Castellanos de Losada es de los pocos nacidos en Madrid, tendencia que irá incrementándose en la segunda mitad del siglo XIX.

Entre los pocos que realizaron una actividad investigadora importante en provincias se encuentra Góngora en la Universidad de Granada, Demetrio de los Ríos de Arquitecto Municipal en Sevilla, Rodríguez de Berlanga en el Banco de Málaga o Hernández Sanahuja de comerciante en Tarragona, tardíamente nombrado Director-conservador del Museo en 1865.

No deja de llamar la atención que fuera la provincia de Tarragona, y su antigua ciudad Tarraco, la que influyera por nacimiento en las vocaciones de tres de los principales arqueólogos de este periodo, Ivo de la Cortina en Italica y Tarraco, Saavedra en Numancia y Hernández Sanahuja en Tarraco, mientras que Casiano del Prado tuvo mucho contacto con la ciudad entre 1835-40 mientras fue Inspector de Minas de Aragón y Cataluña. Otro tanto habría que decir de Sevilla y la antigua ciu- dad de Italica, donde excavaron Ivo de la Cortina, Amador de los Ríos y Demetrio de los Ríos, ciudad donde vivió y coleccionó monedas Antonio Delgado.

En la documentación gráfica de las excavaciones, destaca el cuidado que presentan los trabajos del arquitecto Demetrio de los Ríos, el pintor Ivo de la Cortina y en particular, la del ingeniero y arquitecto Eduardo Saavedra, pero lamentablemente no publicaron una memoria detallada de sus excavaciones en Itálica y Numancia, que minimizó la importancia de sus investigaciones. Llama la atención el uso regular de prisioneros como mano de obra por los gobernadores civiles en los yacimientos importantes como Mérida, Itálica, Cártama o Guarrazar.

Otro aspecto evidente es la mínima repercusión internacional de la investigación realizada en España. Sólo cabe señalar como excepciones a Gayangos por la redacción en inglés de la traducción de al-Maqqari, The History of the Mohammedan Dynasties in Spain (1840-43), de Amador de los Ríos con Estudios históricos, políticos y literarios sobre los judios de España (1848), traducido a otros idiomas como el francés (de los Ríos, 1848/1861), y los libros de Rodríguez de Berlanga por su solidez y preparación de ediciones en latín de Aeris salpensani (1858), Aeris malacitani (1861a) o Monumenta historica malacitana (1863).

En esta etapa entre 1830-67, por su obra científica y los cargos que desempeñaron, los arqueólogos más relevantes fueron José Amador de los Ríos y Serrano y Antonio Delgado y Hernández. El primero fue el Secretario de la Comisión Central de Monumentos Provinciales entre 1844-57, redactor del Proyecto de creación de un Museo Nacional de Antigüedades en 1853, del que llegó a ser su director en 1868, del Reglamento de las Comisiones Provinciales de Monumentos Históricos y Artísticos en 1865 y principal representante de la Arqueología Monumental con Manuel de Assas. Tenía una buena formación arqueológica que aprendió colaborando en las excavaciones de Itálica con Ivo de la Cortina entre 1839-40, que posteriormente dirigió entre 1841-43. La segunda gran figura fue Antonio Delgado, Anticuario de la Real Academia de la Historia entre 1848-66, Director de la Escuela Superior de Diplomática entre 1858-65 y Catedrático en la escuela de Epigrafía y Geografía Antiguas y de la Edad Media entre 1863-65.

De los orientalistas, claramente destacan Gayangos en el arabismo y García Blanco entre los hebraístas, que no fueron superados en la segunda mitad del siglo XIX, como tampoco Delgado en 
Numismática o Rodríguez de Berlanga en Epigrafía, si no incluimos a Hübner. La Prehistoria estaba en una etapa germinal, aunque merece destacarse la labor de Casiano del Prado colaborando en la primera identificación de útiles paleolíticos para la Península Ibérica y las aportaciones de Góngora sobre el Neolítico y el arte rupestre esquemático.

\section{Obras más REPRESENTATIVAS}

Las obras numismáticas de Delgado se elaboraron principalmente en la década de los años cincuenta, aunque su trabajo publicado más representativo de este momento es la Memoria históricocrítica sobre el gran disco de Teodosio, encontrado en Almendralejo (1849), con un buen encuadre histórico. En José Amador de los Ríos resalta su estudio del arte visigodo en El arte latino-bizantino en España y las coronas visigodas de Guarrazar (1861). Para los filólogos, el trabajo probablemente más destacado sea el Diqduq, Análisis filosófico de la escritura y lengua hebreas (1846-51) del hebraísta García Blanco, y entre los arabistas, la traducción de al-Maqqari, The History of the Mohammedan Dynasties in Spain (1840-43) por Gayangos.

Resulta difícil comparar las contribuciones de Amador de los Ríos y Delgado con la solidez de dos de los primeros libros de Hübner, que tratan además de hacer un análisis a escala nacional, Die Antiken Bildwerke in Madrid (1862), donde estudia todas las esculturas, bronces y cerámicas grecoromanas en colecciones españolas y en particular, el Corpus de Inscriptiones Latinae II. Inscriptiones Hispaniae Latinae (1869) de la Península Ibérica. El único autor que aporta una solidez científica contemporánea a la época son los trabajos de Rodríguez de Berlanga, ya anunciado en Estudios sobre los dos bronces encontrados en Málaga a fines de octubre de 1851 (1853) y culminado en Monumentos históricos del Municipio Flavio Malacitano (1864). También lo son las dos obras principales de Delgado en numismática, redactadas en esta época, Nuevo método de clasificación de las medallas autónomas de España (1871-73) y Estudios de Numismática Arábigo-Hispana considerada como comprobante histórico de la dominación islámica de la Península (1864), que no vio la luz hasta 2001.

\section{Agradecimientos}

Este trabajo se adscribe al Grupo de Investigación Hum F-003 de la Universidad Autónoma de Madrid, sobre estudios historiográficos, dirigido por Juan Blánquez. Queremos agra- decer la amabilidad de los funcionarios del Archivo General de la Administración y la discusión a lo largo de varios años de aspectos de la historia de la arqueología con Alicia Canto, Gloria Mora y en particular Jorge Maier.

\section{Bibliografía}

ABASCAL PALAZÓN, J.M. (1995): "Excavaciones y hallazgos numismáticos de Fernando Sepúlveda en Valderrebollo (1877-1879)". Wad-al-Hayara, 22: 151-175.

ADÁN ÁlVAREZ, G.E. (1999): "La Comisión de Monumentos Históricos y Artísticos de Asturias y su imbricación en los Museos Asturianos durante el siglo XIX y principios del XX (1844-1919): El Museo Arqueológico Provincial". Boletín de la Asociación Española de Archiveros, Bibliotecarios, Museólogos y Documentalistas, 49 (2): 175-204.

ALFARO ASINS, C. (1993): "Las colecciones numismáticas del M.A.N.". En A. Marcos Pous (ed.): De Gabinete a Museo. Tres siglos de historia. Museo Arqueológico Nacional (Madrid, 1993). Museo Arqueológico Nacional-Ministerio de Cultura. Madrid: 147-158.

ALMAGRO BASCH, M. (1951): Las fuentes escritas referentes a Ampurias. Monografías Ampuritanas, I. Diputación Provincial de Barcelona-Consejo Superior de Investigaciones Científicas. Barcelona.

ALMAGRO GORBEA, M. (1999): "El Gabinete de Antigüedades de la Real Academia de la Historia. Pasado, Presente y Futuro". En M. Almagro Gorbea (ed.): El Gabinete de Antigüedades de la Real Academia de la Historia (Madrid, 1998). Real Academia de la Historia. Madrid: 15-173.

ALMAGRO GORBEA, M. (2003): "El Archivo de la Comisión de Antigüedades: una visión de conjunto". En M. Almagro Gorbea y J. Maier (eds.): 250 años de Arqueología y Patrimonio (Madrid, 2002). Real Academia de la Historia. Madrid: 209-224.

ALMAGRO GORBEA, M. y MAIER, J. (1999): “El futuro desde el pasado: la Real Academia de la Historia y el origen y funciones del Museo Arqueológico Nacional". Boletín de la Real Academia de la Historia, 196 (2): 183-207.

ÁLVAREZ MILLÁN, C. (2004): "Pascual de Gayangos y la historia medieval de España”. Espacio, Tiempo y Forma. Serie III. Historia Medieval, 17: 37-51.

ÁLVAREZ SANCHÍS, J.; CARDITO, L.Mª ; PÉREZ OLMEDO, E. y ORTIZ DE URBINA, C. (2000): Comisión de Antigüedades de la Real Academia de la Historia. Castilla y León. Catálogo e Índices. Real Academia de la Historia. Madrid.

ARTOLA GALLEGO, M. (1973): La burguesía revolucionaria (1808-1869). En M. Artola (ed.): Historia de España Alfaguara. V. Alianza Universidad. Madrid.

ASSAS y de EREÑO, M. de (1839): Diccionario General de Arquitectura. Burgos. 
ASSAS y de ERENO, M. de (1846): "Apuntes sobre el origen y progresos de la Arquitectura". Boletín Español de Arquitectura, 1: 49-51, 59-60, 78-79, 8384, 91-92 y 100 .

ASSAS y de EREÑO, M. de (1848): Álbum artístico de Toledo. Julián Saavedra y Cía. Madrid.

ASSAS y de EREÑO, M. de (1857a): "Nociones fisionómico-históricas de la Arquitectura en España. 1. Monumentos Célticos". Semanario Pintoresco Español, 22: 129-133, 140-142, 148-149, 155-158, $163-165$ y $172-173$.

ASSAS y de EREÑO, M. de (1857b): "Nociones fisionómico-históricas de la Arquitectura en España. 2. Monumentos fenicios". Semanario Pintoresco Español, 22: 177-179.

ASSAS y de EREÑO, M. de (1857c): "Nociones fisionómico-históricas de la Arquitectura en España. 3. Monumentos ciclópeos o pelásgicos". Semanario Pintoresco Español, 22: 193-194 y 196-197.

ASSAS y de EREÑO, M. de (1857d): "Nociones fisionómico-históricas de la Arquitectura en España. 4. Monumentos griegos". Semanario Pintoresco Español, 22: 201-202, 209-210, 217-218, 225-226, 233-234 y 241-243.

ASSAS y de EREÑO, M. de (1857e): "Nociones fisionómico-históricas de la Arquitectura en España. 5. Monumentos cartagineses". Semanario Pintoresco Español, 22: 252-253.

ASSAS y de EREÑO, M. de (1857f): "Nociones fisionómico-históricas de la Arquitectura en España. 6. Monumentos romanos". Semanario Pintoresco Español, 22: 257-259, 265-269, 273-274, 281-283, 289-292, 297-299, 305-306, 313-314, 321-323, 329$330,345-346,353-354,361-363,369-372,379-380$, 385-387 y 393-394.

BAENA del ALCÁZAR, L. (1988): "La colección de antiguiedades romanas de la Finca de San José". Mainake, 10: 137-150.

BAENA del ALCÁZAR, L. (2003): “Semblanza de D. Manuel de Góngora y Martínez (1822-1884) y sus estudios sobre Arqueología Clásica". Baética, 25: 355-375.

BALMASEDA MUNCHARAZ, L.J. (1995a): "El Tesoro perdido de Guarrazar". Archivo Español de Arqueología, 68 (171-172): 149-164.

BALMASEDA MUNCHARAZ, L.J. (1995b): "La reclamación diplomática del Tesoro de Guarrazar". Boletín de la ANABAD, 45 (1): 165-175.

BALMASEDA MUNCHARAZ, L.J. (1996): "Las versiones del hallazgo del tesoro de Guarrazar". Homenaje a Mercedes Rueda Sabater in Memoriam. Boletín del Museo Arqueológico Nacional, 14: 95 110

BALMASEDA MUNCHARAZ, L.J. (1997): "El modelo de Guarrazar: Real Academia de la Historia y presidiarios de una excavación decimonónica". En G. Mora y M. Díaz-Andreu (eds.): La cristalización del pasado: génesis y desarrollo del marco institucional de la arqueología en España. II Congreso
Internacional de Historiografía de la Arqueología en España (siglos XVIII-XX) (Madrid, 1995). Universidad de Málaga-C.S.I.C.-Ministerio de Educación y Cultura. Málaga: 207-213.

BALMASEDA MUNCHARAZ, L.J. (1999): "El diamantista José Navarro y el tesoro de Guarrazar". Boletín del Museo Arqueológico Nacional, 17 (1-2): 175-188.

BALLESTER TORMO, I. (1937): "El Castellet del Porquet (Ollería)". Trabajos Varios del Servicio de Investigaciones Prehistórica, 1. Valencia: 3-21.

BEAUD, M. (1981/1984): Historia del capitalismo. De 1500 a nuestros días. Ariel. Barcelona.

BELMONTE y CLEMENTE, F. (1880): Noticia biográfica de D. Antonio Delgado y Hernández. Sevilla.

BELMONTE y CLEMENTE, F. (1880/2001): "Noticia biográfica de D. Antonio Delgado y Hernández”. En A. Delgado y Hernández, Estudios de Numismática Arábigo-Hispana considerada como comprobante histórico de la dominación islámica de la Península. A. Canto García y T. ibn Hafiz Ibrahim (eds.). Real Academia de la Historia. Madrid: xxxvii-xl.

BELTRÁN FORTES， J. (1997): “Arqueología e Instituciones en la Sevilla del siglo XIX. La Diputación Arqueológica”. En G. Mora y M. DíazAndreu (eds.): La cristalización del pasado: génesis y desarrollo del marco institucional de la arqueología en España. II Congreso Internacional de Historiografía de la Arqueología en España (siglos XVIII-XX) (Madrid, 1995). Universidad de MálagaC.S.I.C.-Ministerio de Educación y Cultura. Málaga: 321-329.

BERLANGA PALOMO, Ma.J. (2001): "La enseñanza de la arqueología en el siglo XIX: de las cátedras de Castellanos de Losada a la introducción en los estudios universitarios". Anales de Arqueología Cordobesa, 12: 13-33.

BERLANGA PALOMO, M.J. (2005): Arqueología y erudición en la Málaga durante el siglo XIX. Universidad de Málaga-Cajamar. Málaga.

BERNAL de O'REILLY, A. (1877): Jerusalén, la Semana Santa. Lamaignère. Bayona.

BERNAL de O'REILLY, A. (1878): Viaje a Oriente, en Egipto. Victoriano Suárez. Madrid.

BERNAL de O'REILLY, A. (1888): En el Líbano, cartas y relaciones sobre la Siria. Biblioteca Popular Ilustrada. Madrid.

BERNAL de O'REILLY, A. (1898): En Tierra Santa: la Judea, la Samaria y la Galilea. Hijos de R. Baroja. San Sebastián.

BOUCHER de PERTHES, J. (1847): Antiquités celtiques et antédiluviennes; mémoire sur l'industrie primitive et les arts à leur origine. Treuttel et Wurtz, Derache. Paris.

BOUCHER de PERTHES, J. (1860): De l'homme antédiluvien et de ses auvres. Jung-Treuttel. Paris.

BOUCHER de PERTHES, J. (1861): "Sobre los sílex encontrados en el diluvium del departamento de la Somme: observaciones de M. Boucher de Perthes 
con motivo de una reciente comunicación sobre las piedras trabajadas por los primitivos habitantes de las Galias”. Revista Minera, 12: 250-254.

BUSCATÓ, L. y PONS, L. (2001): "La Real Academia de la Historia y los yacimientos de Rhode y Emporion en el s. XIX". Boletín de la Real Academia de la Historia, 198 (1): 155-174.

CALLE MARÍN, S. (2004): "La Academia frustrada: la Real de Arqueología y Geografía del Príncipe Alfonso (1837-1868)". En J.L. Gómez Pantoja (ed.): Excavando papeles. Indagaciones arqueológicas en los archivos españoles. Aache Ediciones. Guadalajara: 121-151.

CÁNOVAS DEL CASTILLO, A. (1883): El Solitario y su tiempo. Biografía de D. Serafín Estébanez Calderón. I-II. Imprenta de A. Pérez Dubrull. Madrid.

CANTO y de GREGORIO, A.M. (1994): “Un precursor hispano del CIL en el siglo XVIII: El marqués de Valdeflores". Boletín de la Real Academia de la Historia, 191 (3): 499-516.

CANTO y de GREGORIO, A.M. (2001): "Ivo de la Cortina y su obra 'Antigüedades de Itálica' (1840): una revista arqueológica malograda". Cuadernos de Prehistoria y Arqueología de la Universidad Autónoma de Madrid, 27: 153-161.

CANTO y de GREGORIO, A.M. (2003): "El Conde de Campomanes. Arqueólogo y epigrafista". Boletín de la Real Academia de la Historia, 200 (1): 23-53.

CARR, R. (1980/1983): España: de la Restauración a la democracia, 1875-1980. Ariel. Barcelona.

CASTELLANOS DE LOSADA, B.S. (1840): Cartilla Numismática o repertorio de las palabras técnicas de la ciencia de las medallas escrita para el uso de los alumnos de la Cátedra de Arqueología del Colegio Universal de Humanidades de Don Sebastián de Fábregas y de los de la misma ciencia en el Ateneo, Liceo e Instituto Español, por el profesor de ellas. Imprenta de J. Sancha. Madrid.

CASTELLANOS DE LOSADA, B.S. (1844-45): Compendio elemental de Arqueología. I-III. Imprenta de Vicente Lalama. Madrid.

CASTELLANOS DE LOSADA, B.S. (1845): Arqueología Artística Monumental. Imprenta de Vicente Lalama. Madrid.

CASTELLANOS DE LOSADA, B.S.; GONZÁLEZ MATE, P. y BERMÚDEZ, F. (1838-39): Galería Numismática Universal o colección de monedas, medallas y bajos relieves, antiguos y modernos, con una introducción extensa a la numismática que puede servir para el estudio elemental de esta, compuesta por el expresado Sr. Castellanos. I-II. Imprenta de la Compañía Tipográfica. Madrid.

CAUMONT, A. de (1830-41): Cours d'antiquités monumentales: histoire de l'art dans l'ouest de la France, depuis les temps les plus reculés jusqu'au XVIIe siècle. Lange. Paris.

CEBRIÁ, A.; MURO, I. y RÍU, E. (1991): "La arqueología y la prehistoria en el siglo XIX: actitudes y conflictos científico-sociales en la Cataluña de la
Restauración". En J. Arce y R. Olmos (eds.): Historiografía de la Arqueología y de la Historia Antigua en España (Siglos XVIII-XX) (Madrid, 1988). Ministerio de Cultura. Madrid: 79-84.

CELESTINO, J. y CELESTINO, S. (2000): Comisión de Antigüedades de la Real Academia de la Historia. Extremadura. Catálogo e Índices. Real Academia de la Historia. Madrid.

CORTINA y ROPERTO, I. de la (1845): “Antigüiedades de Itálica”. Semanario Pintoresco Español, 1845 (1): 29-31.

DELAUNY, J.-M. (1997): "La Dame de Elche, actriz de las relaciones franco-españolas del siglo XIX". En R. Olmos y T. Tortosa (eds.): La Dama de Elche. Lecturas desde la diversidad. La Arqueología de la Mirada, 2. Lynx. Madrid: 100-106.

DELGADO y HERNÁNDEZ, A. (1864/2001): Estudios de Numismática Arábigo-Hispana considerada como comprobante histórico de la dominación islámica de la Península. A. Canto García y T. ibn Hafiz Ibrahim (eds.). Real Academia de la Historia. Madrid

DELGADO y HERNÁNDEZ, A. (1871-73): Nuevo método de clasificación de las medallas autónomas de España. I-II. Imprenta de D. Antonio Izquierdo y García. Sevilla.

DÍAZ-ANDREU, M.; MORA, G. y CORTADELLA, J. (2009): Diccionario histórico de la Arqueología en España. Marcial Pons Historia. Madrid.

ESCRIBANO MARTÍN, F. (2005): “Adolfo Rivadeneyra, un diplomático español al servicio del estudio y del viaje por Oriente". En J. Córdoba (ed.): Españoles en Oriente Próximo (1166-1926). Aventureros y peregrinos, militares, científicos $y$ diplomáticos olvidados en el redescubrimiento de un mundo. Arbor, 180 (711-712): 789-804.

FABIE ESCUDERO, A.Ma . (1877): "Necrológica del Sr. D. Antonio Delgado y Hernández". Boletín de la Real Academia de la Historia, 1 (4): 409-422.

FERNÁNDEZ DE BÉTHENCOURT, F. (1912): "Discurso leído por el Excmo. Sr. D. Francisco Fernández de Béthencourt en la velada necrológica celebrada por el Centro de Defensa Social de Madrid el 12 de Abril de 1912, en memoria del Excmo. Sr. D. Eduardo Saavedra y Moragas". Boletín de la Real Academia de la Historia, 60 (6): 537-546.

FERNÁNDEZ y GONZÁLEZ, F. (1858): La idea de lo bello y sus conceptos fundamentales. Disertación leída en la Universidad Central al recibir la investidura de Doctor. Imprenta de Manuel Galiano. Madrid.

FERNÁNDEZ y GONZÁLEZ, F. (1860): Historias de Al-Andalus por Aben-Abharí de Marruecos. Imprenta de F. Ventura. Granada.

FERNÁNDEZ y GONZÁLEZ, F. (1866): Estado social y político de los mudéjares de Castilla, considerados en sí mismos y respecto de la civilización española. Imprenta a cargo de J. Muñoz. Madrid.

FERNÁNDEZ-MIRANDA, M. y PEREIRA, J. (1992): "Indigenismo y orientalización en la tierra de Talavera". I Jornadas de Talavera de la Reina y sus tierras. Talavera de la Reina: 57-63. 
FONTANA LÁZARO, J. (2007): La época del liberalismo. En J. Fontana y R. Villares (eds.): Historia de España. 6. Crítica-Marcial Pons. Barcelona.

FORONDA y AGUILERA, Manuel de, FORONDA, Marqués de (1912): "Saavedra, iniciador, fundador, socio y Presidente efectivo y honorario de la Real Sociedad Geográfica de Madrid”. Boletín de la Real Sociedad Geográfica, 54 (4): 411-424.

GALI y LASSALETTA, A. (1892/2001): Historia de Itálica, municipio y colonia romana: S. Isidro del Campo, Sepulcro de Guzmán el Bueno, Santiponce, Sevilla. Ediciones de Andalucía. Sevilla.

GARCÍA BLANCO, A.M. (1846-51): Diqduq. Análisis filosófico de la escritura y lengua hebreas. I-III. Imprenta de Eusebio Aguado (I). Imprenta de José Félix Palacios (II). Imprenta y librería de la viuda de José Vázquez Martínez e hijos (III). Madrid.

GARCÍA BLANCO, A.M. (1869): Biografía de D. Antonio María García Blanco escrita por sí mismo, o sea, historia compendiada de los conocimientos hebreos en España. Imprenta de Tomas Rey y Compañía. Madrid.

GARCÍA BLANCO, A.M. (1887): Historia compendiada de una larga vida. Resumen de un siglo. Imprenta de M. Ledesma Vidal. Osuna.

GANAU i CASAS, J. (1999): La protección de los monumentos arquitectónicos en España y Cataluña, 1844 1836: legislación, organización, inventario. Universitat de Lleida. Lleida.

GAYANGOS y ARCE, P. de (1840-43): The History of the Mohammedan Dynasties in Spain. The Asiatic Society. London.

GAYANGOS y ARCE, P. de (1861): Principios elementales de la escritura arábiga y modelo de escritura. Madrid.

GERONA, Marqués de, CASTRO y OROZCO, J. de (1843): "Sierra Elvira, Granada". La Alhambra, 2 (7): 121-124.

GÓMEZ DE LA SERNA y TULLY, P. (1840-50): Curso histórico-exegético de Derecho Romano comparado con el español. I-II. Imprenta de la Compañía de Impresores y Libreros del Reino. Madrid.

GÓMEZ-MORENO MARTÍNEZ, M. (1953): "Unas cartas de El Solitario". Boletín de la Real Academia Española, 32: 209-242.

GÓMEZ PÉREZ, J. (1958): “Castellanos de Losada y la Real Academia de Arqueología y Geografía”. Revista de Archivos, Bibliotecas y Museos, 65: 561-567.

GÓNGORA y MARTÍNEZ, M. de (1860a): Viaje literario por las provincias de Granada y Jaén. Ms. Real Academia de la Historia. Madrid.

GÓNGORA y MARTÍNEZ, M. de (1860/1915-16/1986): Viaje literario por las provincias de Granada y Jaén. Imprenta, papelería y librería de Morales y Cruz. Jaén. Don Lope de Sosa, 1915: 117s, 148s, 175s, 211 s, 247s, 277s, 343s y 375s. Don Lope de Sosa, 16: $6 \mathrm{~s}, 38 \mathrm{~s}, 81 \mathrm{~s}, 147 \mathrm{~s}, 216 \mathrm{~s}$ y $281 \mathrm{~s}$.
GÓNGORA y MARTÍNEZ, M. de (1860b): Espíritu y hechos generales determinantes de las Cruzadas: modificaciones de aquel espíritu desde la Primera Cruzada a las últimas, e influencia de este hecho histórico en la civilización. Imprenta de Luis Beltrán. Madrid.

GÓNGORA y MARTÍNEZ, M. de (1867): "Memoria premiada por la Real Academia de la Historia fijando definitivamente el sitio de la colonia Salariense". Revista de Bellas Artes e Histórico-Arqueológica, 2 (54): 42-48.

GÓNGORA y MARTÍNEZ, M. de (1868): Antigüedades prehistóricas de Andalucía. Monumentos, inscripciones, armas, utensilios y otros importantes objetos pertenecientes a los tiempos más remotos de su población. Imprenta C. Moro. Madrid.

GÓNGORA y MARTÍNEZ, M. de (1870a): "Antigüedades prehistóricas. Cartas acerca de algunos nuevos descubrimientos". La Ilustración de Madrid, 1: 4-6, 11-14.

GÓNGORA y MARTÍNEZ, M. de (1870b): Apuntes biográficos del Excmo. Sr. D. José de Castro y Orozco, Marqués de Gerona. Comisión de Monumentos de Granada. Imprenta de D. Paulino Ventura y Sabatel. Granada.

GÓNGORA y MARTÍNEZ, M. de (1878/1882): Lecciones de Historia Universal y particular de España. Imprenta de La Lealtad a cargo de J.J. Garrido. $1^{\text {a }}$ edición. Granada. Establecimiento tipográfico de Góngora y Compañía. $2^{a}$ ampliada. Madrid.

GÓNGORA y MARTÍNEZ, M. de (1879/1882): Nociones de Historia Universal y de España. Imprenta y librería de José López Guevara. $1^{\text {a }}$ edición. Granada. Establecimiento tipográfico de Góngora y Compañía. $2^{\mathrm{a}}$ ampliada. Madrid.

GÓNGORA y MARTÍNEZ, M. de (1880/1882): Nociones de Historia General de España. Imprenta de la Viuda de Puchol. $1^{\text {a }}$ edición. Granada. Establecimiento tipográfico de Góngora y Compañía. $2^{\mathrm{a}}$ ampliada. Madrid.

GÓNGORA y MARTÍNEZ, M. de (1881a): "Los brazaletes prehistóricos". La Ilustración Española y Americana, 30 de abril de 1881: 278-279.

GÓNGORA y MARTÍNEZ, M. de (1881b): Nociones de Geografía. Imprenta de la Viuda de Puchol. Granada.

GONZÁLEZ ALONSO, E. (1997): "Lancia. Fuentes e Historiografía”. Lancia, 2: 181-206.

GONZÁLEZ RUIBAL, A. (2000): Comisión de Antigüedades de la Real Academia de la Historia. Galicia. Catálogo e Índices. Real Academia de la Historia. Madrid.

GOURY, J. y JONES, O. (1842): Planos, alzados, secciones y detalles de la Alhambra de dibujos tomados en el lugar en 1834 por el difunto M. Jules Goury y en 1834 y 1837 por Owen Jones, arquitecto, con una traducción completa de las inscripciones árabes; y unas notas históricas sobre los reyes de Granada, desde la conquista de esa ciudad por los árabes hasta la expulsión de los moros, por Mr. Pascual de Gayangos. London. 
HERNÁNDEZ y SANAHUJA, B. (1855): Resumen histórico-crítico de la ciudad de Tarragona desde su fundación hasta la época romana, con una explicación de los fragmentos del sepulcro egipcio descubierto el 9 de marzo de 1850. Imprenta J. Antonio Nel-lo. Tarragona.

HÜBNER, E. (1859): De senatus populique Romani actis. Teubner. Leipzig.

HÜBNER, E. (1860): "Epigraphische Reiseberichte aus Spanien und Portugal". Monatsberichte der Königlichen Preuss. Akademie der Wissenschaften zu Berlin (Phil.-Hist. Klasse), 1860: 231-241, 324-332, 421-450 y 594-643.

HÜBNER, E. (1861): "Epigraphische Reiseberichte aus Spanien und Portugal". Monatsberichte der Königlichen Preuss. Akademie der Wissenschaften zu Berlin (Phil.-Hist. Klasse), 1861: 16-113, 377-405, 525-549, 721-837 y $938-986$.

HÜBNER, E. (1862a): Die Antiken Bildwerke in Madrid. Georg Reimer. Berlin.

HÜBNER, E. (1862/2008): Las colecciones de arte antiguo en Madrid. J. Maier y Th.G. Schattner (eds.). Instituto Arqueológico Alemán de Madrid. Madrid.

HÜBNER, E. (1862b): "Inscriften von Carmona. Trigueros und Franco, zwei spanische Inschriftensammler". Rheinisches Museum, 17: 228267.

HÜBNER, E. (1869): Corpus de Inscriptionum Latinarum. II. Inscriptiones Hispaniae Latinae. Academiae Litterarum Regiae Borussiae. Georgium Reimerum. Berolini-Berlin.

HÜBNER, E. (1871): Inscriptiones Hispaniae Christianae. Georgium Reimerum. Berolini-Berlin.

HÜBNER, E. (1873): Corpus de Inscriptionum Latinarum. VII. Inscriptiones Britanniae Latinae. Academiae Litterarum Regiae Borussiae. Georgium Reimerum. Berolini-Berlin.

HÜBNER, E. (1876): Grundriss zu Vorlesungen über die Geschichte und Encyklopädie der klassischen Philologie. Weidmann. Berlin.

HÜBNER, E. (1877): “Additamenta ad Corporis volumen II". Ephemeris Epigraphica, 3: 31-52.

HÜBNER, E. (1878): Grundriss zu Vorlesungen über die römische Litteraturgeschichte. Weidmann. Berlin.

HÜBNER, E. (1880): Grundriss zu Vorlesungen über die lateinische Grammatik. Weidmann. Berlin.

HÜBNER, E. (1883): Grundriss zu Vorlesungen über die griechische Syntax. Weidmann. Berlin.

HÜBNER, E. (1888): La arqueología de España. Tipografía-Litografía de los Sucesores de Ramírez y $\mathrm{C}^{\mathrm{a}}$. Barcelona.

HÜBNER, E. (1892): Corpus de Inscriptionum Latinarum. II. Inscriptiones Hispaniae Latinae supplementum. Berlin.

HÜBNER, E. (1893): Monumenta Linguae Ibericae. Georgii Reimeri. Berolini-Berlín.
HÜBNER, E. (1899): “Additamenta nova ad Corporis volumen II”. Ephemeris Epigraphica, 8: 351-479.

HÜBNER, E. (1900): Inscriptionum Hispaniae Christianarum supplementum. Georgii Reimeri. Berolini-Berlin.

HÜBNER, E. (1903): "Additamenta nova ad Corporis volumen II”. Ephemeris Epigraphica, 9: 12-185.

HUICI GOÑI, Mª.P. (1990): "Las Comisiones de Monumentos Históricos y Artísticos con especial referencia a la Comisión de Navarra". Príncipe de Viana, 51 (189): 119-209.

IBARRA y MANZONI, A. (1879): Illici, su situación y antigüedades. Establecimiento Tipográfico de Antonio Reus. Alicante.

IBARRA y MANZONI, A. (1879/1981): Illici, su situación y antigüedades. Instituto de Estudios Alicantinos, Serie II, 14. Diputación Provincial de Alicante. Alicante.

JIMÉNEZ DÍEZ, J.A. y MEDEROS, A. (2001): Comisión de Antigüedades de la Real Academia de la Historia. Baleares. Canarias. Melilla. Gibraltar. Extranjero. Catálogo e Índices. Real Academia de la Historia. Madrid.

JIMÉNEZ FRAUD, A. (1971): Historia de la Universidad Española. Libro de Bolsillo, 335. Alianza Editorial. Madrid.

JIMENO MARTÍNEZ, A. y TORRE ECHÁVARRI, J.I. de la (2005): Numancia, símbolo e historia. Akal Arqueología, 6. Madrid.

KRAUSE, K.C.F. (1837/1995): Compendio de Estética. Editorial Verbum. Madrid.

LABOULAYE, E. (1856): Les tables de bronze de Malaga et de Salpensa traduites et annotées. Revue historique de droit français et étranger. Durand. Paris.

LAFUENTE ALCÁNTARA, E. (1859): Inscripciones árabes de Granada, precedidas de una reseña histórica y de la genealogía detallada de los reyes Alahmares. Imprenta Nacional. Granada.

LARA ESCOZ, J.I. (2007): "La Comisión de Monumentos Históricos y Artísticos de Sevilla en el siglo XIX. Una perspectiva arqueológica”. En M. Belén y J. Beltrán Fortes (eds.): Las instituciones en el origen y desarrollo de la arqueología en España. III Reunión Andaluza de Historiografía Arqueológica (Sevilla, 2003). Spal Monografías, 10. Universidad de Sevilla. Sevilla: 67-92.

LARA PEINADO, F. (1969-70): "Historia del Museo Arqueológico de Lérida. (Con el estudio de sus piezas más importantes)”. Ilerda, 30: 75-93.

LARTET, L. (1866): "Poteries primitives, instruments en os et sílex taillés de la Vieille Castille (Espagne)". Revue Archéologique, 1866: 114-134.

LASTEYRIE du SAILLANT, F.Ch.L. de (1860): Description du Trésor de Guarrazar. Gide éditeur. Paris.

LAVIN BERDONCES, A.C. (1997): "La figura de Castellanos de Losada en la arqueología española del siglo XIX". Boletín del Museo Arqueológico Nacional, 15: 249-257. 
LAVIN BERDONCES, A.C. (1999): Comisión de Antigüedades de la Real Academia de la Historia. Navarra. Catálogo e Índices. Real Academia de la Historia. Madrid.

LÁZARO GALDEANO, J. (1925): El robo de la Real Armería y las coronas de Guarrazar. La España Moderna. Madrid.

LÓPEZ MENDIZABAL, I. (1899): Cantabria y la guerra cantábrica como medio de averiguar el estado en que se encontraban las actuales provincias Bascongadas en tiempos de Augusto. Imprenta de E. López. Tolosa.

LUMIARES, Conde de, VALCÁRCEL PÍO de SABOYA y MOURA, Antonio (1800/1852): Inscripciones y Antigüedades del reino de Valencia. A. Delgado (ed.). Memorias de la Real Academia de la Historia, 8. Madrid.

LUZÓN NOGUÉ, J.Ma . (1993): "La Real Academia de Arqueología y Geografía del Príncipe Alfonso". A. Marcos Pous (ed.): De Gabinete a Museo. Tres siglos de historia. Museo Arqueológico Nacional (Madrid, 1993). Museo Arqueológico Nacional-Ministerio de Cultura. Madrid: 271-275.

LUZÓN NOGUÉ, J.Mª (1999): Sevilla la Vieja. Un paseo histórico por las ruinas de Itálica. Fundación Focus-Abengoa. Sevilla.

MACHADO y NÚÑEZ, A. (1869): "Congreso internacional de Arqueología prehistórica". Revista Mensual de Filosofía, Literatura y Ciencias, 1: 33-39 y 281287.

MAIER ALLENDE, J. (1998): Comisión de Antigüedades de la Real Academia de la Historia. Madrid. Catálogo e Índices. Real Academia de la Historia. Madrid.

MAIER ALLENDE, J. (1999): Comisión de Antigüedades de la Real Academia de la Historia. Castilla-La Mancha. Catálogo e Índices. Real Academia de la Historia. Madrid.

MAIER ALLENDE, J. (2003a): "La Comisión de Antigüedades de la Real Academia de la Historia". En M. Almagro Gorbea y J. Maier (eds.): 250 años de Arqueología y Patrimonio. Real Academia de la Historia. Madrid: 27-51.

MAIER ALLENDE, J. (2003b): Noticias de Antigüedades de las Actas de Sesiones de la Real Academia de la Historia (1792-1833). Real Academia de la Historia. Madrid.

MAIER ALLENDE, J. (2008): Noticias de Antigüedades de las Actas de Sesiones de la Real Academia de la Historia (1834-1874). Real Academia de la Historia. Madrid.

MAIER, J. y MARTÍNEZ PEÑARROYA, J. (2001): "Casiano del Prado y Vallo (1797-1866): arqueología y política en la España romántica". Estudios de Prehistoria y Arqueología Madrileñas, 11: 115-125.

MAIER, J. y SALAS, J. (2007): "Los Inspectores de Antigüedades de la Real Academia de la Historia en Andalucía”. En M. Belén y J. Beltrán Fortes (eds.): Las instituciones en el origen y desarrollo de la arqueología en España. III Reunión Andaluza de Historiografía Arqueológica (Sevilla, 2003). Spal Monografías, 10. Universidad de Sevilla. Sevilla: 175-238.

MAIER, J.; SALAS, J.; BERLANGA, Ma .J. y BELLÓN, J.P. (2000): Comisión de Antigüedades de la Real Academia de la Historia. Andalucía. Catálogo e Índices. Real Academia de la Historia. Madrid.

MAÑAS MARTÍNEZ, J. (1983): Eduardo Saavedra, ingeniero y humanista. Colegio de Ingenieros de Caminos Reales y Puertos-Ediciones Turner. Madrid.

MAÑAS MARTÍNEZ, J. (2007): "Eduardo Saavedra y su entorno”. Ingeniería y Territorio, 79: 86-89.

MARCOS POUS, A. (1993): “Origen y desarrollo del Museo Arqueológico Nacional". En A. Marcos Pous (ed.): De Gabinete a Museo. Tres siglos de historia. Museo Arqueológico Nacional (Madrid, 1993). Museo Arqueológico Nacional-Ministerio de Cultura. Madrid: 21-99.

MARTÍN ASUERO, P. (2005): "Representantes españoles en el imperio Otomano, entre la diplomacia, la crónica y la literatura (1864-1886)". En J. Córdoba (ed.): Españoles en Oriente Próximo (1166-1926). Aventureros y peregrinos, militares, científicos y diplomáticos olvidados en el redescubrimiento de un mundo. Arbor, 180 (711-712): 773-788.

MARTÍN ESCUDERO, F.; CEPAS, A. y CANTO GARCÍA, A. (2004): Archivo del Gabinete Numario. Catálogo e índices. Real Academia de la Historia. Madrid.

MARTÍNEZ CUADRADO, M. (1973): Restauración y crisis de la monarquía (1874-1931). En M. Artola (ed.): Historia de España Alfaguara. VI. Alianza Universidad. Madrid.

MATEU y LLOPIS, F. (1949): "Cartas numismáticas de don Jacobo Zóbel de Zangróniz a don Álvaro Campaner y Fuertes (1862-1881). Seleccionadas y anotadas". Boletín de la Real Academia de la Historia, 125 (1): 87-159.

MEDEROS MARTÍN, A. (2003): "Islas Canarias". En M. Almagro Gorbea y J. Maier (eds.): 250 años de Arqueología y Patrimonio (Madrid, 2002). Real Academia de la Historia. Madrid: 195-207.

MEDEROS MARTÍN, A. (e.p.): "Análisis de una decadencia. La arqueología española del siglo XIX. II. La crisis de la Restauración (1868-1900)". Cuadernos de Prehistoria y Arqueología de la Universidad Autónoma de Madrid, 37 (2011).

MENÉNDEZ y PELAYO, M. (1967): Historia de los Heterodoxos Españoles. I-II. Biblioteca de Autores Cristianos. Madrid.

MIRANDA VALDÉS, J. (2005): Aureliano FernándezGuerra y Orbe (1816-1894). Un romántico, escritor y anticuario. Anticuaria Hispánica, 10. Real Academia de la Historia. Madrid.

MITJANA y ARDISON, R. (1847): Memoria sobre el templo druida hallado en las cercanías de Antequera. Imprenta de D. José Martínez de Aguilar. Málaga. 
MOMMSEN, T. (1855): "Die Stadtrechte der lateinischen Gemeinden Salpensa und Malaca in der Provinz Baetica". Abhandlungen der Königlichen Sachsischen Gessellschaft der Wissenschaften zu Leipzig, 1855 (3): 363-507.

MORA RODRÍGUEZ, G. (1988): "Trigueros y Hübner. Algunas notas sobre el concepto de falsificación". Archivo Español de Arqueología, 61 (157-158): 344-348.

MORA, G.; TORTOSA, T. y GÓMEZ GÓMEZ, Mª.A. (2001): Comisión de Antigüedades de la Real Academia de la Historia. Valencia. Murcia. Catálogo $e$ Índices. Real Academia de la Historia. Madrid.

MORENO NIETO, J. (1872): Gramática de la lengua arábiga. Imprenta de M. Rivadeneyra. Madrid.

NÚÑEZ MUÑOZ, Ma.F. (1986): La Universidad en Canarias. Una aproximación a su evolución histórica. Centro de la Cultura Popular Canaria-Cabildo Insular de Tenerife. Tenerife.

OLLERO de la TORRE, A. (1990): "El catedrático logroñés Dr. Zubia. (Contribución a la Historia de la Enseñanza Media en Logroño durante la época que ejerció la docencia este ilustre riojano)". Zubía, 8: 193-210.

OLMEDO CHECA, M. (1985): "Manuel Rodríguez de Berlanga: un hombre singular en la Málaga del XIX". Jábega, 49: 71-80.

OLMEDO CHECA, M. (2000): “Introducción”. En M. Rodríguez de Berlanga, Monumentos Históricos del Municipio Flavio Malacitano. Diputación Provincial de Málaga. Málaga: 9-129.

OLÓZAGA, S. de; DELGADO, A. y FERNÁNDEZGUERRA, A. (1897): "Excavaciones hechas en el cerro de Garray, donde se cree que estuvo situada Numancia". Boletín de la Real Academia de la Historia, 1: 55-59.

ORTIZ de URBINA, C. (1999): Comisión de Antigüedades de la Real Academia de la Historia. País Vasco. Catálogo e Índices. Real Academia de la Historia. Madrid.

ORTIZ de ZÁRATE, R. (1848): Jamás los romanos conquistaron completamente a los Vascongados y nunca estos belicosos pueblos formaron parte integrante del Imperio de los Césares. Imprenta, Litografía y Librería Egaña. Vitoria.

PAPÍ RODES, C. (2009): "Ibarra y Manzoni, Aureliano". En M. Díaz-Andreu, G. Mora y J. Cortadella (eds.): Diccionario histórico de la Arqueología en España. Marcial Pons Historia. Madrid: 341-342.

PASAMAR, G. y PEIRÓ, I. (2002): Diccionario Akal de Historiadores españoles contemporáneos (18401980). Akal. Madrid.

PASTOR MUÑOZ, M. y PACHÓN ROMERO, J. (1991): "D. Manuel de Góngora y Martínez: biografía y obra". En M. Góngora, Antigüedades prehistóricas de Andalucía. Monumentos, inscripciones, armas, utensilios y otros importantes objetos pertenecientes a los tiempos más remotos de su población. Archivum, 27. Universidad de Granada. Granada: xiii-lxv.
PAVÓN y LÓPEZ, F. de B. (1878): "El Excmo. Sr. D. José Amador de los Ríos y Padilla, Diario de Córdoba, 27 y 28 de febrero de 1878". Necrológicas de varios contemporáneos distinguidos especialmente cordobeses: dadas a luz con anterioridad en varias fechas y publicaciones y ahora coleccionadas. Córdoba: 105-121.

PEIRÓ MARTÍN, I. y PASAMAR, G. (1996): La Escuela Superior de Diplomática (los archiveros en los historiografía española contemporánea). Asociación Española de Archiveros, Bibliotecarios, Museólogos y Documentalistas. Madrid.

PENGELLY, W. (1849-50): "On the ichthyolites of East Cornwall". Transactions of the Royal Geological Society Cornwall, 7: 106-108 y 115-120.

PÉREZ DE BARRADAS, J. (1928): "El descubridor del hombre fósil en España. Don Casiano de Prado y Vallo". Investigación y Progreso, 2 (1): 1-4.

PRADO y VALLO, C. de (1837): "Baco en Tarragona". El Observatorio Pintoresco, 1 (5-6): 19-21.

PRADO y VALLO, C. de (1858): "Restos de un mastodonte en las cercanías de Madrid". Revista Minera, 9 (205): 749 .

PRADO y VALLO, C. de (1864): Descripción física y geológica de la provincia de Madrid. Imprenta Nacional. Madrid.

PRADO y VALLO, C. de (1866): Temperatura por que la Tierra ha pasado en la sucesión de los tiempos geológicos. Discursos leídos ante la Real Academia de Ciencias Exactas, Físicas y Naturales en la recepción pública del Excmo. Sr. D. Casiano del Prado. Imprenta de Eusebio Aguado. Madrid.

PRADO, C. de y VERENEUIL, E. de (1850): "Note géologique sur les terrains de Sabero et de ses environs dans les montagnes de Leon (Espagne) par D. Casiano del Prado suivie d'une description des fossiles de ces terrains par M. Ed. de Verneuil". Bulletin de la Société Géologique de France, 7 (2): 137-186.

PRADO, C. de; VERENEUIL, E. de y BARRANDE, J. (1860): "Sur l'existance de la faune primordiale dans la chaine cantabrique, por M. Casiano de Prado suivi de la description des fósiles, par MM. De Verneuil et Barrande". Bulletin de la Société Géologique de France, 17: 516-554

PRESTWICH, J. (1860): "On the occurrence of flint implements associated with remains of animals of extinct species in beds of a late geological period in France at Amiens and Abbeville and in England at Hoxne". Philosophical Transactions of the Royal Society of London, 150: 277-327.

PUCHE RIART, O. (2004): "Casiano del Prado y Valle". En M. Ayarzagüena y G. Mora (eds.): Pioneros de la Arqueología en España del siglo XVI a 1912. Zona Arqueológica, 3: 79-87.

RADA y DELGADO, J. de D. de la (1872): "Coronas de Guarrazar que se conservan en la Armería Real de Madrid". Museo Español de Antigüedades, 3: 113132. 
RADA y DELGADO, J. de D. de la (1890): "La corona de Suintila". En A. Fernández-Guerra y E. Hinojosa, Historia de España desde la invasión de los pueblos germánicos hasta la ruina de la monarquía visigoda. I .Ten A. Cánovas del Castillo (ed.): Historia General de España. Real Academia de la Historia. El Progreso Editorial. Madrid: 437-474.

REMESAL, J.; AGUILERA, A. y PONS, L. (2000): Comisión de Antigüedades de la Real Academia de la Historia. Cataluña. Catálogo e Índices. Real Academia de la Historia. Madrid.

RENERO ARRIBAS, V.M. (2004): "Manuel de Assas y Ereño". En M. Ayarzagüena y G. Mora (eds.): Pioneros de la Arqueología en España del siglo XVI a 1912. Zona Arqueológica, 3: 95-101.

RIGOLLOT, J.P. (1854): “Memoire sur les instruments en silex trouvés à Saint-Acheul, près d'Amiens, et considerés sous les rapports géologiques et archéologiques". Mémoire de la Société des Antiquaries de Picardie, 14: 22-60.

RIVADENEYRA SÁNCHEZ, A. (1871): Viaje de Ceilán a Damasco. Golfo Pérsico. Mesopotamia. Ruinas de Babilonia, Nínive y Palmira. Madrid.

RIVADENEYRA SÁNCHEZ, A. (1871/1986): De Ceilán a Damasco. Laertes. Barcelona.

RIVADENEYRA SÁNCHEZ, A. (1880): Viaje al interior de Persia. I-III. Imprenta y Estereotipia de Aribau y $\mathrm{C}^{\mathrm{a}}$. Madrid.

RÍOS y SERRANO, D. de los (1862/2002): Memoria Arqueológica-Descriptiva del Anfiteatro de Itálica, acompañada del plano y restauración del mismo edificio. Memorias de la Real Academia de la Historia. Madrid.

RÍOS y SERRANO, D. de los (1872): "Descripción del Mosaico de las Musas descubierto en 1839". Museo Español de Antigüedades, 1: 185-192.

RÍOS y SERRANO, D. de los (1879): Itálica. Historia y descripción artística de esta infortunada ciudad. Ms. Biblioteca Nacional. Madrid.

RÍOS y SERRANO, J.A. de los (1844): Sevilla pintoresca, ó descripción de sus más célebres monumentos artísticos. F. Álvarez. Sevilla.

RÍOS y SERRANO, J.A. de los (1845a): Toledo pintoresca, ó descripción de sus más célebres monumentos. I. Boix. Madrid.

RÍOS y SERRANO, J.A. de los (1845b): Itálica: historia de esta ciudad famosa desde su fundación hasta nuestros días, con todos sus descubrimientos. Ms. Museo Arqueológico de Sevilla. Sevilla.

RÍOS y SERRANO, J.A. de los (1848): Estudios históricos, políticos y literarios sobre los judios de España. Imprenta de D.M. Díaz. Madrid.

RÍOS y SERRANO, J.A. de los (1848/1861): Éstudes historiques, politiques et littéraires sur les juifs d'Espagne. Trad. J.-G. Magnaval. Imprimerie administrative de Paul Dupont. Paris.

RÍOS y SERRANO, J.A. de los (1859): El estilo mudéjar en la arquitectura. Discursos leídos ante la Real
Academia de Nobles Artes de San Fernando en la recepción pública de don José Amador de los Ríos. Contestación por D. Pedro de Madrazo. Imprenta de M. Rivadeneyra. Madrid

RÍOS y SERRANO, J.A. de los (1861): El arte latinobizantino en España y las coronas visigodas de Guarrazar: ensayo histórico-crítico. Memorias de la Real Academia de Bellas Artes de San Fernando. Imprenta Nacional. Madrid.

RÍOS y SERRANO, J.A. de los (1861-65): Historia crítica de la literatura española. I-VII. Imprenta de J. Rodríguez. Madrid.

RÍOS y SERRANO, J.A. de los (1862): “Algunas consideraciones sobre la estatuaria, durante la monarquía visigoda". El Arte en España, 1: 15-165.

RÍOS y SERRANO, J.A. de los (1875-76): Historia social, política y religiosa de los judíos en España y Portugal. I-III. Imprenta de T. Fortanet. Madrid.

RÍOS y SERRANO, J.A. de los (1877a): Monumentos latino-bizantinos de Mérida. Monumentos Arquitectónicos de España. Imprenta y calcografía nacional. Madrid.

RÍOS y SERRANO, J.A. de los (1877b): "Cabezas de bronce encontradas en el sitio llamado de Máquiz, término de Menjíbar". Boletín de la Real Academia de la Historia, 1: 27-32.

RÍOS y SERRANO, J.A. de los y AMADOR de los RÍOS y FERNÁNDEZ DE VILLALTA, R. (1879): Monumentos latino-bizantinos de Córdoba. Monumentos Arquitectónicos de España. Imprenta y calcografía nacional. Madrid.

RÍOS y SERRANO, J.A. de los; RADA y DELGADO, J. de D. de la y ROSELL, C. (1860-64): Historia de la Villa y Corte de Madrid. I-IV. Imprenta Ferrá de Mena. Madrid.

RIVIÈRE GÓMEZ, A. (2000): Orientalismo y nacionalismo español. Estudios árabes y hebreos en la Universidad de Madrid (1843-1868). Biblioteca del Instituto Antonio de Nebrija, 3. Universidad Carlos III-Editorial Dykinson. Madrid.

ROCA, P. (1897): "Noticias de la vida y obras de don Pascual de Gayangos". Revista de Archivos, Bibliotecas y Museos, $3^{\mathrm{a}}$. S., 1 (12): 544-565.

ROCA, P. (1898): "Noticias de la vida y obras de don Pascual de Gayangos". Revista de Archivos, Bibliotecas y Museos, $3^{\text {a }}$. S., 2 (1): 13-22, 2 (2): 7082, 2 (3): $110-130$ y 2 (12): 562-568.

ROCA, P. (1899): "Noticias de la vida y obras de don Pascual de Gayangos". Revista de Archivos, Bibliotecas y Museos, $3^{\text {a }}$. S., 3 (2): 101-106.

RODRÍGUEZ DE BERLANGA y ROSADO, M. (1852): Discurso sobre el Derecho Internacional Privado de Roma desde sus primeros días hasta la destrucción del Imperio de Occidente, pronunciado en la Universidad de Madrid al recibir la investidura de Doctor. Madrid.

RODRÍGUEZ DE BERLANGA y ROSADO, M. (1853): Estudios sobre los dos bronces encontrados en Málaga a fines de octubre de 1851. Imprenta del 
Avisador Malagueño. Málaga. Revista semanal pintoresca del Avisador Malagueño, 7: 49-56, 8: 57-64, 9: 65-72, 10: 73-80, 11: 81-88 y 12: 89-94.

RODRÍGUEZ DE BERLANGA y ROSADO, M. (1858): Aeris salpensani exemplus, fideliter expressum auctoritate Academiae editum rerum historicarum Regiae matritensis, sumptibus Georgii Loringii, cuius in aedibus tabula aenea servatur Malacae, ubi eruta fuit anno MDCCCLI, e revisione et accuratissima emendatione. Litografía de Francisco Mitjana. Malacae.

RODRÍGUEZ DE BERLANGA y ROSADO, M. (1859): "Ensayo de una nueva versión castellana del bronce salpensano". Revista General de Legislación y Jurisprudencia, 14: 118-127, 407-418 y 497-507.

RODRÍGUEZ DE BERLANGA y ROSADO, M. (1861a): Aeris malacitani exemplum, tantummodo marginibus omissis, fideliter expressum auctoritate Academiae editum rerum historicarum Regiae matritensis, sumptibus Georgii Loringii, cuius in aedibus tabula aenea servatur Malacae, ubi eruta fuit anno MDCCCLI, e revisione et accuratissima emendatione. Litografía de Francisco Mitjana. Malacae.

RODRÍGUEZ DE BERLANGA y ROSADO, M. (1861b): Estudios romanos publicados en La Razón. I. A la Señora Doña Amalia Heredia de Loring, Marquesa de Casa-Loring. II. A Mr. Guillermo Henzen, secretario del Instituto Arqueológico de Roma. III, Al Sr. D. Jorge Loring, Marqués de CasaLoring. IV, A Theodoro Mommsem, miembro del Instituto Arqueológico de Roma. V, A. M. Emilio Hübner, miembro del Instituto Arqueológico de Roma. Imprenta de Manuel Galiano. Madrid. I, 5-15. II, 16-49. III, 50-70. IV, 71-185 y V, 1-118.

RODRÍGUEZ DE BERLANGA y ROSADO, M. (1861c): Estudios romanos. II. A Mr. Guillermo Henzen, secretario del Instituto Arqueológico de Roma. Imprenta del Avisador Malagueño. Málaga.

RODRÍGUEZ DE BERLANGA y ROSADO, M. (1863): Monumenta historica malacitana quotquot genuina supersunt ab oppidi incunabulis ad Imperii Romani excidium. Malacae.

RODRÍGUEZ DE BERLANGA y ROSADO, M. (1864): Monumentos históricos del Municipio Flavio Malacitano. Málaga.

RODRÍGUEZ DE BERLANGA y ROSADO, M. (1868): Catálogo de algunas antigüedades reunidas y conservadas por los Excmos. Señores Marqueses de Casa-Loring en su Hacienda de la Concepción. Málaga.

RODRÍGUEZ DE BERLANGA y ROSADO, M. (1901): "Estudios epigráficos. Iliberis". Boletín de la Asociación Artístico Arqueológica Barcelonesa, 3 (26): $185-210$ y (28): 313-321.

RODRÍGUEZ HIDALGO, J.M. (2007): “La colección arqueológica de Itálica. Apuntes sobre su ampliación e institucionalización durante el siglo XIX". En J. Beltrán (eds.): Arqueología, Coleccionismo y Antigüedad: España e Italia en el siglo XIX (Sevilla, 2004). Universidad de Sevilla. Sevilla: 545-579.
RODRÍGUEZ OLIVA, P. (1991): "Manuel Rodríguez de Berlanga (1825-1909): Notas sobre la vida y la obra un estudioso andaluz del mundo clásico". En J. Arce y R. Olmos (eds.): Historiografía de la Arqueología y de la Historia Antigua en España (siglos XVIII-XX) (Madrid, 1988). Ministerio de Cultura. Madrid: 99-106.

ROMERO RECIO, M. (2007): "La Arqueología en la enseñanza española durante el siglo XIX: nuevas aportaciones a la luz de documentos inéditos". En J. Beltrán (eds.): Arqueología, Coleccionismo y Antigüedad: España e Italia en el siglo XIX (Sevilla, 2004). Universidad de Sevilla. Sevilla: 581-601.

RUIZ CABRIADA, A. (1958): Bio-Bibliografía del Cuerpo Facultativo de Archiveros, Bibliotecarios y Arqueólogos. 1858-1958. Junta Técnica de Archivos, Bibliotecas y Museos. Madrid.

SAAVEDRA y MORAGAS, E. (1861/1879): Descripción de la Vía romana de Uxama a Augustóbriga. Memorias de la Real Academia de la Historia, 9. Madrid.

SAAVEDRA y MORAGAS, E. (1861/2000): Descripción de la Vía romana de Uxama a Augustóbriga. Fascímil. E. Baquedano y C. Caballero (ed.). Colegio de Ingenieros de Caminos, Canales y Puertos. Madrid-Soria.

SAAVEDRA y MORAGAS, E. (1862): Las obras públicas en los antiguos tiempos, y de los caminos romanos. Discursos leídos ante la Real Academia de la Historia en la recepción pública de Don Eduardo Saavedra, el día 28 de diciembre de 1862. Contestación por el Señor D. Aureliano FernándezGuerra y Orbe. Imprenta de Manuel Galiano. Madrid.

SAAVEDRA y MORAGAS, E. (1881-83): La geografía de España del Edrisí. Imprenta del Fortanet. Madrid. Boletín de la Real Sociedad Geográfica de Madrid, 10 (1) (1881): 249-255 y 376-387, 11 (2) (1881): 102-114, 12 (1) (1882): 46-54 y 13 (1) (1883): 81-91.

SAAVEDRA y MORAGAS, E. (1883): "Discurso en elogio de D. Adolfo Rivadeneyra". Boletín de la Real Sociedad Geográfica de Madrid, 12 (2): 495-513.

SAAVEDRA y MORAGAS, E. (1892): Estudio sobre la invasión de los árabes en España. Imprenta de El Progreso Editorial. Madrid.

SAAVEDRA y MORAGAS, E. (1894): "D. Buenaventura Hernández y Sanahuja". Boletín de la Real Academia de la Historia, 25 (5): 337-368.

SAAVEDRA y MORAGAS, E. (1897): "Don Pascual de Gayangos". La Ilustración Española y Americana, 38, 15 de octubre de 1897: 226-227.

SAAVEDRA y MORAGAS, E. (1901): "Necrológica. Emilio Hübner". Boletín de la Real Academia de la Historia, 39: 413-419.

SACY, S. de (1831): Grammaire arabe à l'usage des éleves de l'école spéciale des langues orientales vivantes. I-II. $2^{\mathrm{a}}$ ed. Paris.

SADA, P. y MASSÓ, J. (1997): "El Museo Arqueológico de Tarragona: un siglo y medio de historia". En G. Mora y M. Díaz-Andreu (eds.): La cristalización del pasado: génesis y desarrollo del marco institucional de la arqueología en España. II Congreso 
Internacional de Historiografía de la Arqueología en España (siglos XVIII-XX) (Madrid, 1995). Universidad de Málaga-C.S.I.C.-Ministerio de Educación y Cultura. Málaga: 149-162.

SALAS, J. y MAIER, J. (2003): "Andalucía, Ceuta y Melilla". En M. Almagro Gorbea y J. Maier (eds.): 250 años de Arqueología y Patrimonio (Madrid, 2002). Real Academia de la Historia. Madrid: 175-193.

SÁNCHEZ BIEDMA, J. (1868): Noticia Biográfico-bibliográfica del Ilmo. Sr. D. Basilio Sebastián Castellanos de Losada Serrano y Castro, director literario de la 'Biografía Eclesiástica Completa'. Imprenta de D. Alejandro Gómez Fuentenebro. Madrid.

SCHULTEN, A. (1953): Cincuenta y cinco años de investigaciones en España. Asociación de Estudios Reusenses-Torrell de Reus Editor. Reus.

SCHULZ y SCHWEIZER, G.P.D. (1854): "Mina antiquísima en Asturias". Revista Minera, 5: 95-96.

SCHULZ y SCHWEIZER, G.P.D. (1858): Atlas geológico y topográfico de Asturias. Litografía de G. Pfeiffer. Madrid.

SEPÚLVEDA y LUCIO, F. (1995): "Memoria de las Antigüedades en Valderrebollo". J.M. Abascal (ed.). Wad-al-Hayara, 22: 152-163.

SIETE IGLESIAS, Marqués de, VÁRGAS-ZÚÑIGA y MONTERO de ESPINOSA, A. (1979): "Real Academia de la Historia. Catálogo de sus individuos. Noticias sacadas de su archivo". Boletín de la Real Academia de la Historia, 175 (1): 19-105, 175 (2): 309-352 y 175 (3): 533-574.

SIETE IGLESIAS, Marqués de, VÁRGAS-ZÚÑIGA y MONTERO de ESPINOSA, A. (1979): "Real Academia de la Historia. Catálogo de sus individuos. Noticias sacadas de su archivo". Boletín de la Real Academia de la Historia, 176 (1): 7-37, 176 (2): 288 365, 176 (3): 499-538 у 176 (4): 689-739.

SIETE IGLESIAS, Marqués de, VÁRGAS-ZÚÑIGA y MONTERO de ESPINOSA, A. (1980): "Real Academia de la Historia. Catálogo de sus individuos. Noticias sacadas de su archivo". Boletín de la Real Academia de la Historia, 177 (2): 289-334 y 177 (3): 575-607.

SIETE IGLESIAS, Marqués de, VÁRGAS-ZÚÑIGA y MONTERO de ESPINOSA, A. (1981): "Real Academia de la Historia. Catálogo de sus individuos. Noticias sacadas de su archivo". Boletín de la Real Academia de la Historia, 178 (1): 57-103.

SILVA, J. Possidonio da (1878): Noções elementares de archeologia. Lallemant frères. Lisboa.

SILVA, J. Possidonio da (1887): Resumo elementar de archeologia christã. Museu de Archeologia do Carmo. Lisboa.

STYLOW, A.U. y GIMENO, H. (2004): "Emil Hübner". En M. Ayarzagüena y G. Mora (eds.): Pioneros de la Arqueología en España del siglo XVI a 1912. Zona Arqueológica, 3: 333-340.

TORMO y MONZÓ, E. (1947): "Homenaje español a la memoria de Emil Hübner: el fundador de la moderna arqueología hispánica". Boletín de la Real Academia de la Historia, 121: 489-566.
TORRES AGUILAR-AMAT, S. (1882): "Elogio de Don José Moreno Nieto y examen de sus trabajos geográficos". Boletín de la Sociedad Geográfica de Madrid, 12 (2): 476-494.

TORTELLA CASARES, G. (1981): "La economía española, 1830-1900". En M. Tuñón de Lara (ed.): Historia de España. VIII. Revolución burguesa, oligarquía y constitucionalismo (1834-1923). Labor. Barcelona: 9-167.

TORTOSA, T. y MORA, G. (1996): "La actuación de la Real Academia de la Historia sobre el patrimonio arqueológico: ruinas y antigüedades". Archivo Español de Arqueología 69 (173-174): 191-217.

TUÑ́N DE LARA, M. (1960/1973): La España del siglo XIX. Editorial Laia. Barcelona.

VALLVÉ BERMEJO, J. (1997): "Pascual de Gayangos (1809-1897): A propósito del centenario de su muerte". Boletín de la Real Academia de la Historia, 194: 461-488.

VALVERDE y PERALES, F. (1903a): “D. José María de los Ríos y Serrano". Historia de la Villa de Baena. Imprenta y librería de la Viuda e hijos de J. Peláez. Toledo: 405-410.

VALVERDE y PERALES, F. (1903b): "D. José Amador de los Ríos". Historia de la Villa de Baena. Imprenta y librería de la Viuda e hijos de J. Peláez. Toledo: 418-433.

VALVERDE y PERALES, F. (1903c): "D. Demetrio de los Ríos y Serrano". Historia de la Villa de Baena. Imprenta y librería de la Viuda e hijos de J. Peláez. Toledo: 439-445.

VALVERDE y PERALES, F. (1903/1982): Historia de la Villa de Baena. Diputación Provincial de Córdoba. Córdoba.

VERNEUIL, E. y COLLOMB, M. (1864): Carte géologique de l'Espagne et du Portugal, d'aprés leurs propes observations faites de 1849 a 1862. Impr. M. Gauthier. Paris.

VERNEUIL, J. y LARTET, J.L. (1862-63a): "Note sur le calcaire a Lychus des environs de Segura (Aragón)". Bulletin de la Société Geologique de France, 20: 684-697.

VERNEUIL, J. y LARTET, J.L. (1862-63b): “Note sur un silex taillé trouvé dans le diluvium des environs de Madrid". Bulletin de la Société Géologique de France, 20: 698-702.

VILAR, J.B. (1984): "El arabista Pascual de Gayangos en los orígenes de la ciencia numismática española. $\mathrm{Su}$ viaje a París y Londres en 1835". Sharq Al-Andalus, 1: 161-165.

VIÚ y CÁCERES, J. de (1846): Colección de inscripciones y antigüedades de Extremadura. Imprenta de Concha y Co. Cáceres.

VIÚ y CÁCERES, J. de (1846/1852): Extremadura. Colección de Inscripciones y Monumentos, seguida de reflexiones sobre lo pasado, lo presente y el porvenir de estas provincias. I. $2^{\mathrm{a}}$ edición corregida $\mathrm{y}$ notablemente adicionada. Imprenta de Pedro Montero. Madrid 


\section{Normas para la redacción de originales}

1. Los originales deberán estar mecanografiados en formato DIN A-4 con un máximo de 34-36 líneas de 75 caracteres por página. No se podrán aceptar originales con mayor densidad de caracteres por página.

2. Junto con el texto mecanografiado se incluirá una copia del mismo en soporte magnético en formato Wordperfect, Word, o RTF. Se evitará el uso de tabuladores y retornos manuales salvo en los puntos y aparte. En la etiqueta se indicará el título del trabajo, autor/es y formato. Se procurará que el texto venga libre de erratas para facilitar la corrección de pruebas al Consejo de Redacción, ya que no se remitirán pruebas de imprenta a los autores por razones de coste.

3. Los artículos deberán venir acompañados de un resumen en la propia lengua del trabajo y en otra lengua de difusión internacional (español, inglés, francés, italiano, alemán). Los resúmenes tendrán una extensión máxima de 15 líneas de 75 espacios cada una.

4. Los artículos vendrán acompañados por un máximo de seis palabras clave que describan una rápida localización en una búsqueda informatizada por temática, metodología, cronología y localización.

5. La extensión máxima de los trabajos será de 40 páginas de texto y hasta 15 ilustraciones (dibujos o fotografías) si ocupan el evilante de la caja de CuPAUAM (24,5 x 16,5 $\mathrm{cm}$.), o hasta 20 ilustraciones si son de menor tamaño.

6. Todas las ilustraciones vendrán numeradas correlativamente, independientemente de que se trate de fotografía, dibujos a línea, gráficos o tablas. Los dibujos incluirán esca- la gráfica y se procurará que se adapten en sus proporciones a la caja de CUPAUAM (24,5 x 16,5 cm.) -caja completa, media caja horizontal, o cuarto de caja-. Para el grosor de las líneas y densidad de sombras de los dibujos se tendrán en cuenta los porcentajes de reducción necesarios.

No se pueden realizar reproducciones a color. Las tablas de valores o datos vendrán integradas en el procesador de texto, en página aparte, con márgenes adecuados y numeradas correlativamente con el resto de las figuras. No se emplearán los términos "Tabla", "Cuadro", "Mapa", etc. En el caso de que tal cosa no sea posible, vendrán impresas o escritas a máquina electrónica y sin erratas, para que puedan ser reproducidas como una figura.

7. Se acompañará una hoja aparte con los pies de las figuras. Si proceden de otras publicaciones se citará la fuente. Es responsabilidad de los autores asegurar la cesión del copyright de las ilustraciones en caso necesario.

8. En el encabezamiento del trabajo, bajo el título y antes que el resumen, se indicará el nombre del/los autor/es, así como el centro o centros en que trabajen. El remitente indicará en hoja aparte los mismos datos, junto con su dirección, teléfono y fecha de envío del trabajo.

9. Se podrá usar el sistema tradicional de citas o el americano, o uno mixto, a elección del autor.

9.1. En notas cortas (referencia a un trabajo), se pondrá el nombre de éste en caracteres normales -no en mayúsculas-, seguido del año de edición de la obra, 
página o páginas y figura o figuras, todo ello separado por comas. Estas citas figurarán en el texto, entre paréntesis, y no al final ni al pie de la página.

9.2. Las notas largas deberán ir al final del texto, con las referencias bibliográficas igual que en 9.1 .

9.3. Al final del artículo se incluirá la lista de la bibliografía citada, ordenada alfabéticamente según el primer apellido de los autores. Si un autor tienes varias obras citadas, se ordenarán de más antigua a más reciente. Si hay varias obras de un autor en un mismo año, se distinguirán con las letras minúsculas (a, b, c, etc.) que se incluirán también en las referencias de 9.1 y 9.2 .

9.4. Cuando se trate de un libro se citará por este orden: apellidos e inicial del nombre del autor, fecha de edición entre paréntesis, dos puntos, título de la obra y lugar de edición.

9.5. Cuando se trate de un artículo de revista: autor, año, título del artículo entre comillas, nombre de la revista en cursiva, tomo o número, y páginas.

9.6. En colaboraciones en libros colectivos: autor, año, título de la colaboración, título del libro (con el nombre del editor o coordinador en su caso, tomo y páginas, lugar de edición).

9.7. El nombre de los autores irá en letras mayúsculas en la Bibliografía final (no así en el cuerpo del texto, véase 9.1.). El título de los libros y de las revistas, subrayado o en cursiva; el de los artículos de revistas y colaboraciones, entre comillas.
9.8. Si se citan abreviadamente títulos de revistas o series, se emplearán las abreviaturas de CUPAUAM para revistas españolas, y algún sistema reconocido internacionalmente (L'Année Philogique, Archáologische Bibliographie, American Journal of Archaeology) para las extranjeras.

\section{Ejemplos de citas:}

9.1. (Abad Casal, 1991:185).

9.2. ... recientemente. Abad Casal (1991:185) indica que...

9.4. GARCÍA Y BELLIDO, A. (1949): Esculturas romanas de España y Portugal. Madrid.

9.5. ABAD CASAL, L. (1983): "Un conjunto de materiales de la Serreta de Alcoy". Lucentum 2, 173-197.

9.6. BELTRÁN LLORIS, M. (1987): "La España celtibérica: la segunda Edad del Hierro en el Valle del Ebro". Historia General de España y América, 1.2, 255-293. Madrid.

10. Los artículos serán revisados por al menos dos evaluadores del Consejo Consultivo y del Consejo Asesor Externo.

11. El Consejo de Redacción se reserva el derecho de devolver los originales que no se correspondan con la línea de la Revista, o que no cumplan estas normas de redacción. El Consejo asesor, a través de su sistema de evaluación, podrá asimismo sugerir las modificaciones que estime oportunas a los originales aceptados. 